\title{
Design and Synthesis of 1,2-Deoxy-pyranose Derivatives of Spliceostatin A toward Prostate Cancer Treatment
}

Yusuke Yoshikawa $^{\#, a}$, Airi Ishibashi, ${ }^{\sharp,}$, Tsunayoshi Takeharac ${ }^{c}$, Takeyuki Suzukic, Kenichi Murai ${ }^{\mathrm{a}}$, Yasufumi Kaneda ${ }^{\mathrm{b}}$, Keisuke Nimura*b ${ }^{*}$ Mitsuhiro Arisawa*a

a) Graduate School of Pharmaceutical Sciences, Osaka University, Yamada-oka 1-6, Suita, Osaka 565-0871, Japan.el: (+81)6-6879-8226,Fax: (+81)6-6879-8226,E-mail:arisaw@phs.osaka-u.ac.jp

b) Division of Gene Therapy Science, Graduate School of Medicine, Osaka University, 2-2 Yamada-oka, Suita, Osaka 565-0871, Japan. el: (+81) 6-6879-3901; Fax: (+81) 6-6879-3909, E-mail: nimura@gts.med.osaka-u.ac.jp

c) Comprehensive Analysis Center, The Institute of Scientific and Industrial Research, Osaka University, Mihogaoka 8-1, Ibaraki, Osaka 567-0047, Japan

\section{Contents}

1. General Remarks

2. Structure of SF3b complex Inhibitors

3. Reaction Conditions

4. Experimental Procedure

5. Analytical RP-HPLC

6. Biological Assay

7. Reference

8. NMR Spectra

\section{General Remarks}

All reactions were monitored by thin-layer chromatography using silica plate. The products were purified by column chromatography over silica gel (70-230 mesh ASTM or 40-50 $\mu \mathrm{m}$, spherical neutral). ${ }^{1} \mathrm{H}$ NMR and ${ }^{13} \mathrm{C}$ NMR were recorded at $25^{\circ} \mathrm{C}$ on 300 and 75, 400 and 100,500 and $125 \mathrm{MHz}$, respectively, and the chemical shifts are reported relative to $\mathrm{CDCl}_{3}\left({ }^{1} \mathrm{H}, \delta=7.26,{ }^{13} \mathrm{C}, \delta=77.0\right)$. Data for ${ }^{1} \mathrm{H}$ NMR spectra are reported as follows: chemical shift $(\delta \mathrm{ppm})$ (integration, multiplicity, coupling constant $(\mathrm{Hz}))$. Multiplicity and qualifier abbreviations are as follows: $\mathrm{s}=$ singlet, $\mathrm{d}=$ doublet, $\mathrm{t}=$ triplet, $\mathrm{q}=$ quartet, $\mathrm{m}=$ multiplet, $\mathrm{br}=$ broad. Highresolution mass spectra were performed by a mass spectrometer using an orbitrap analyzer. Optical rotations were measured on a polarimeter. 


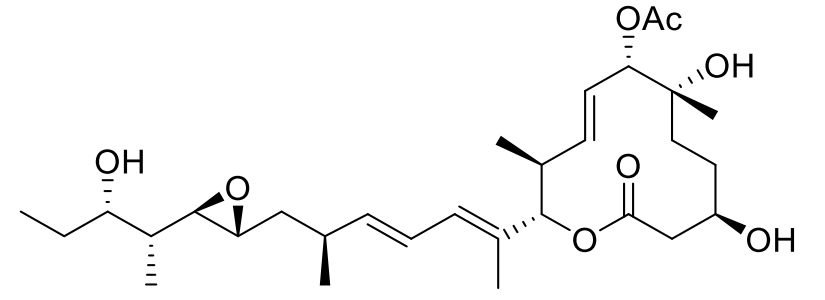

Pladienolide B<smiles>CO[C@H]([C@H](C)O)[C@H](C)[C@H]1O[C@]1(C)C[C@H](C)/C=C/C=C(\C)[C@H]1O[C@H](CC(=O)O)CC[C@H]1C</smiles>

GEX1A

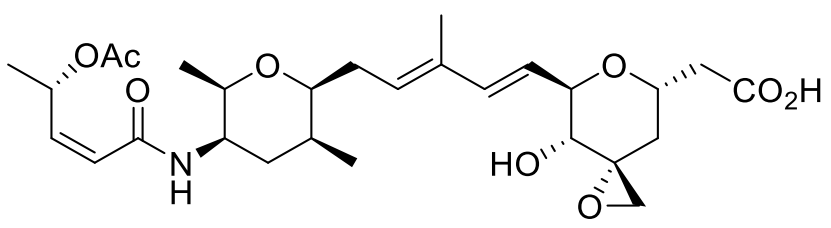

Thailanstatin A

Scheme S1. Structure of Pladienolide B, GEX1A and Thailanstatin A

\section{$\underline{\text { 3. Reaction Conditions }}$}

(1) Wittig reaction of $\mathbf{I}$ and $\mathbf{1 8}$

Conditions for Wittig reactions to build trisubstituted olefins (from I to II and III, and from $\mathbf{1 8}$ to $\mathbf{1 9}$ and 20) are shown below. The type of base and the reaction temperature significantly affect the yields and $E$ and $Z$ selectivity.

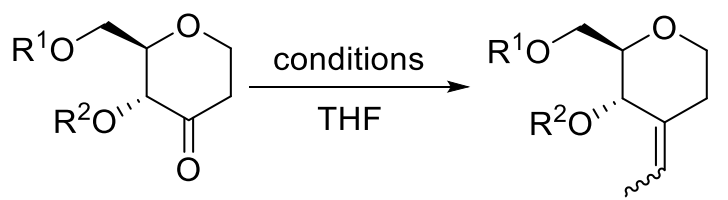

II $\left(R^{1}=\right.$ TBS, $R^{2}=$ TBS, $Z$ isomer $)$ III $\left(\mathrm{R}^{1}=\right.$ TBS, $\mathrm{R}^{2}=$ TBS, $E$ isomer $)$ $19\left(R^{1}=\right.$ TBS, $R^{2}=P M B, Z$ isomer $)$ $20\left(\mathrm{R}^{1}=\mathrm{TBS}, \mathrm{R}^{2}=\mathrm{PMB}, E\right.$ isomer $)$

$\mathrm{I}, \mathrm{R}^{1}=\mathrm{TBS}, \mathrm{R}^{2}=\mathrm{TBS}$ 18, $R^{1}=T B S, R^{2}=P M B$

\begin{tabular}{|c|c|c|c|c|}
\hline entry & & reagent & Base & yield \\
\hline $\begin{array}{l}1 \\
2\end{array}$ & I & $\begin{array}{l}\mathrm{EtPPh}_{3}{ }^{+} \mathrm{Br}^{-} \\
(3.0 \text { eq. })\end{array}$ & $\begin{array}{l}{ }^{t} \mathrm{BuOK} \\
(2.8 \text { eq. })\end{array}$ & $\begin{array}{l}0^{\circ} \mathrm{C} \text { to rt. : trace } \\
0^{\circ} \mathrm{C} \text { to } 40^{\circ} \mathrm{C}: \text { trace }\end{array}$ \\
\hline $\begin{array}{l}3 \\
4\end{array}$ & I & $\begin{array}{l}\mathrm{EtPPh}_{3}{ }^{+} \mathrm{Br}^{-} \\
(3.0 \text { eq. })\end{array}$ & $\begin{array}{c}n \text {-BuLi } \\
\text { (2.8 eq.) }\end{array}$ & $\begin{array}{l}0^{\circ} \mathrm{C} \text { to rt. : trace } \\
0^{\circ} \mathrm{C} \text { to } 40^{\circ} \mathrm{C}: 55 \% \\
(\text { II : III }=5.5: 1)^{\mathrm{a}}\end{array}$ \\
\hline $\begin{array}{l}5 \\
6\end{array}$ & 18 & $\begin{array}{l}\mathrm{EtPPh}_{3}{ }^{+} \mathrm{Br}^{-} \\
(3.0 \text { eq. })\end{array}$ & $\begin{array}{c}{ }^{t} \mathrm{BuOK} \\
(2.8 \text { eq. })\end{array}$ & $\begin{array}{l}0^{\circ} \mathrm{C} \text { to rt.: trace } \\
0^{\circ} \mathrm{C} \text { to } 40^{\circ} \mathrm{C}: \text { trace }\end{array}$ \\
\hline 7 & 18 & $\begin{array}{l}\mathrm{EtPPh}_{3}{ }^{+} \mathrm{Br}^{-} \\
(3.0 \text { eq. })\end{array}$ & $\begin{array}{l}n \text {-BuLi } \\
\text { (2.8 eq.) }\end{array}$ & $\begin{array}{c}93 \%(19: 20=1: 1) \\
\left(0^{\circ} \mathrm{C} \text { to } 40^{\circ} \mathrm{C}\right)\end{array}$ \\
\hline
\end{tabular}

a, Ratio of geometric isomers were determined by $\mathrm{H}^{1} \mathrm{NMR}$

Scheme S2. Wittig reaction of I and $\mathbf{1 8}$ 
(2)

As shown below, the Julia coupling reaction with combination 12 and 7 or 8 was not successful. Introduction of a methyl group into the epoxide group could change the steric environment around the sulfonyl group.

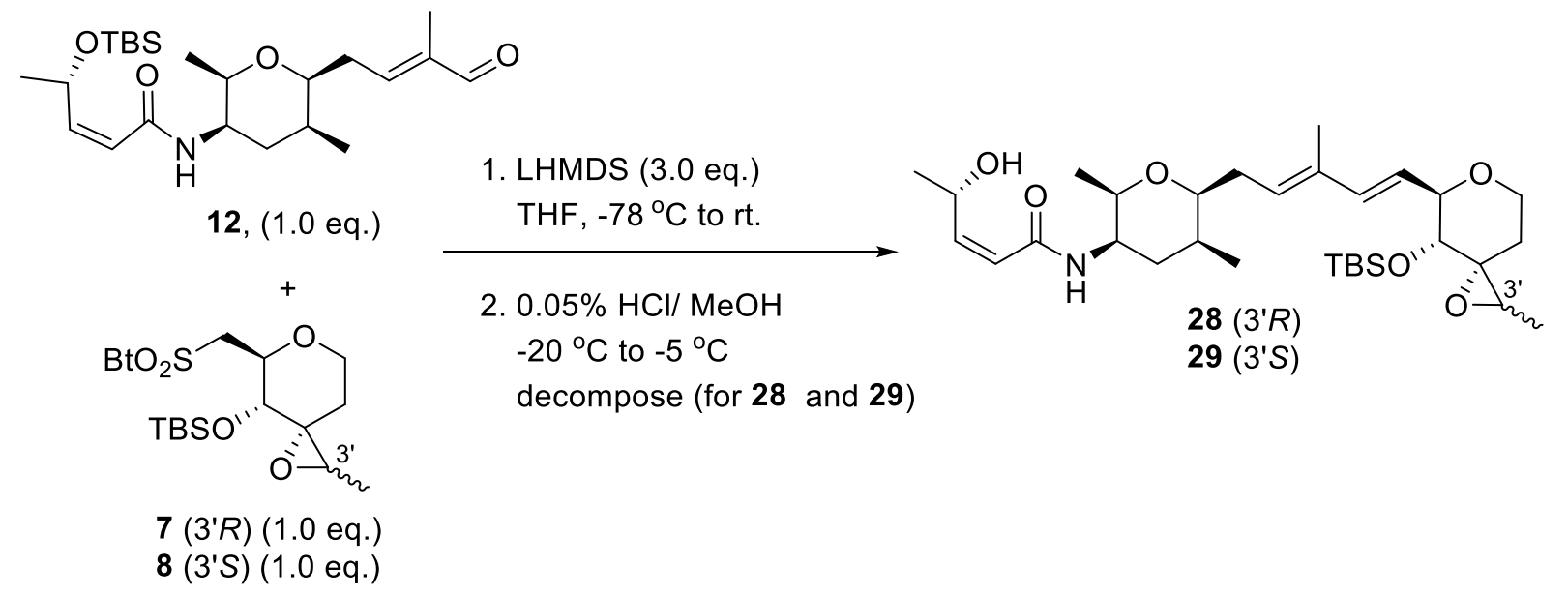

Scheme S3. Julia Kocienski olefination of $\mathbf{1 2}$ and 7, 8

\section{Experimental Procedure}

Preparation and data for $\mathbf{1 6}$ from D-glucal : See reference 1.
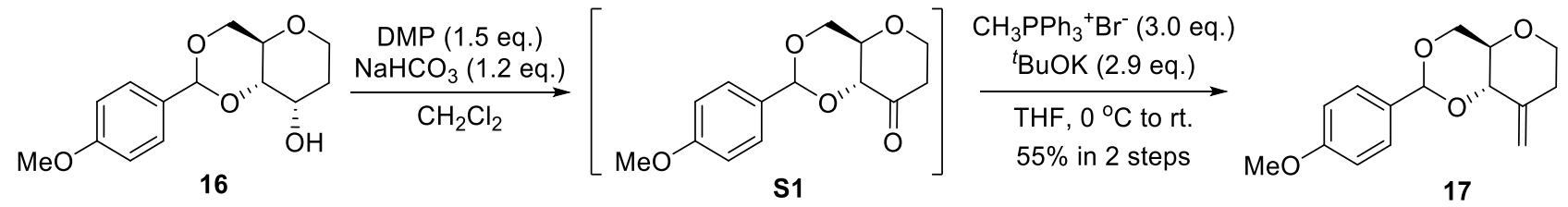

\section{Compound 17}

(Step 1): To a solution of $\mathbf{1 6}$ (250 mg, $0.939 \mathrm{mmol}, 1.0$ equiv.) in dry $\mathrm{CH}_{2} \mathrm{Cl}_{2}$ (10 ml) was added DMP (593 mg, 1.40 mmol, 1.5 equiv.) and $\mathrm{NaHCO}_{3}(94.0 \mathrm{mg}, 1.12 \mathrm{mmol}, 1.2$ equiv.) at room temperature. After stirring for $6 \mathrm{~h}$, the reaction mixture was diluted with $\mathrm{Et}_{2} \mathrm{O}$ and quenched with saturated $\mathrm{NaHCO}_{3}$ aq and saturated $\mathrm{Na}_{2} \mathrm{~S}_{2} \mathrm{O}_{3}$ aq. The organic compounds were extracted with $\mathrm{Et}_{2} \mathrm{O}$. The organic layers were combined, and the solution was dried over anhydrous $\mathrm{Na}_{2} \mathrm{SO}_{4}$, and concentrated under reduced pressure. The residue was passed through a short silica gel column $(n$-hexane $/ \mathrm{EtOAc}=1 / 1)$ to give the crude S1 $(231 \mathrm{mg}, 0.874 \mathrm{mmol})$.

(Step 2): To a solution of $\mathrm{MePPh}_{3}{ }^{+} \mathrm{Br}^{-}$(934 mg, $2.61 \mathrm{mmol}, 3.0$ equiv.) in dry THF (13 ml) was added ${ }^{t} \mathrm{BuOK}$ (285 g, $2.54 \mathrm{mmol}, 2.9$ equiv.) at $0{ }^{\circ} \mathrm{C}$. After stirring for $10 \mathrm{~min}$, a solution of $\mathbf{S} \mathbf{1}(231 \mathrm{mg}, 0.874 \mathrm{mmol}, 1.0$ equiv.) in THF $(5.0 \mathrm{ml})$ was then added via syringe, and then the reaction mixture was warmed to room temperature. After stirring for $20 \mathrm{~min}$, the reaction mixture was quenched with saturated $\mathrm{NH}_{4} \mathrm{Cl}$ aq. The organic compounds were extracted with EtOAc. The organic layers were combined, and the solution was dried over anhydrous $\mathrm{Na}_{2} \mathrm{SO}_{4}$, and concentrated under reduced pressure. The residue was purified by silica gel column chromatography $(n$-hexane/EtOAc $=10 / 1)$ to give 17 (135 mg, $0.514 \mathrm{mmol}, 55 \%$ in 2 steps) as a colorless oil. 
${ }^{1}$ H-NMR $\left(\mathrm{CDCl}_{3}, 400 \mathrm{MHz}\right) \delta: 7.46(2 \mathrm{H}, \mathrm{d}, J=8.7 \mathrm{~Hz}), 6.90(2 \mathrm{H}, \mathrm{d}, J=8.7 \mathrm{~Hz}), 5.61(1 \mathrm{H}, \mathrm{s}), 5.09(1 \mathrm{H}, \mathrm{d}, J=1.8$ $\mathrm{Hz}), 4.89(1 \mathrm{H}, \mathrm{d}, J=1.8 \mathrm{~Hz}), 4.89(1 \mathrm{H}, \mathrm{d}, J=1.8 \mathrm{~Hz}), 4.26(1 \mathrm{H}, \mathrm{dd}, J=10.6,5.0 \mathrm{~Hz}), 4.04(1 \mathrm{H}, \mathrm{dd}, J=10.6,4.6$ $\mathrm{Hz}), 4.01(1 \mathrm{H}, \mathrm{d}, J=9.2 \mathrm{~Hz}), 3.81(3 \mathrm{H}, \mathrm{s}), 3.74(1 \mathrm{H}, \mathrm{dd}, J=10.3,10.3 \mathrm{~Hz}), 3.53(1 \mathrm{H}, \mathrm{ddd}, J=12.4,10.5,2.8 \mathrm{~Hz})$, $3.31(1 \mathrm{H}, \mathrm{ddd}, J=9.2,9.2,5.0 \mathrm{~Hz}), 2.53(1 \mathrm{H}, \mathrm{ddd}, J=14.2,13.7,6.0 \mathrm{~Hz}), 2.36(1 \mathrm{H}, \mathrm{ddd}, J=14.2,1.8,1.8 \mathrm{~Hz}) .{ }^{13} \mathbf{C}-$ NMR; 35.0, 55.2, 69.1, 69.3, 74.8, 80.2, 101.3, 105.8, 113.5, 127.5, 130.2, 142.0, 160.0; HRMS (MALDI-TOF) $\mathrm{m} / \mathrm{z}$ 263.1279 (calcd for $\left.\mathrm{C}_{15} \mathrm{H}_{19} \mathrm{O}_{4}[\mathrm{M}], 263.1278\right)$. $[\alpha]^{23} \mathrm{D}=+37.9$ (c $\left.0.34, \mathrm{CHCl}_{3}\right)$.<smiles>C=C1CCO[C@@H]2COC(c3ccc(OC)cc3)O[C@@H]12</smiles>

17

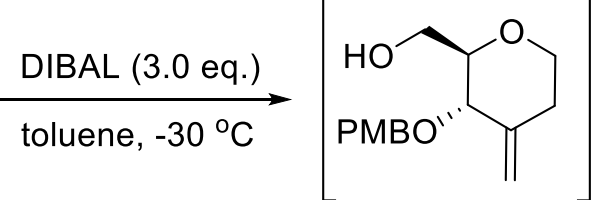

S2

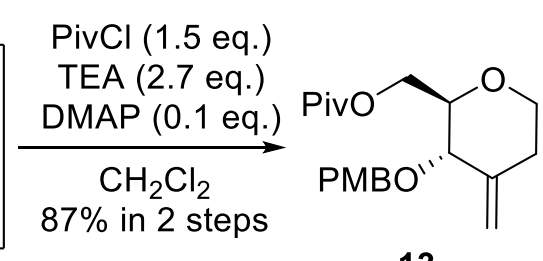

13

\section{Compound 13}

(Step 1): To a solution of $\mathbf{1 7}$ (3.00 g, $11.4 \mathrm{mmol}, 1.0$ equiv.) in dry toluene (110 ml) was added DIBAL (1M toluene solution) ( $34 \mathrm{ml}, 34.0 \mathrm{mmol}, 3.0$ equiv.) at $-30^{\circ} \mathrm{C}$. After stirring for $6.5 \mathrm{~h}$, the reaction mixture was quenched with $\mathrm{MeOH}$ and saturated potassium sodium tartrate aq. The organic compounds were extracted with EtOAc. The organic layers were combined, and the solution was dried over anhydrous $\mathrm{Na}_{2} \mathrm{SO}_{4}$, and concentrated under reduced pressure to give the crude S2 $(2.89 \mathrm{~g}, 10.9 \mathrm{mmol})$.

(Step 2): To a solution of S2 (2.89 g, 10.9 mmol, 1.0 equiv.) in dry $\mathrm{CH}_{2} \mathrm{Cl}_{2}(50 \mathrm{ml})$ were added $\mathrm{PivCl}(2.0 \mathrm{ml}, 16.4$ mmol, 1.5 equiv.), TEA ( $4.0 \mathrm{ml}, 28.9 \mathrm{mmol}, 2.7$ equiv.) and DMAP (133 mg, $1.09 \mathrm{mmol}, 0.1$ equiv.) at room temperature. After stirring for $2 \mathrm{~h}$, the reaction mixture was quenched with $\mathrm{H}_{2} \mathrm{O}$. The organic compounds were extracted with $\mathrm{CH}_{2} \mathrm{Cl}_{2}$. The organic layers were combined, and the solution was dried over anhydrous $\mathrm{Na}_{2} \mathrm{SO}_{4}$, and concentrated under reduced pressure. The residue was purified by silica gel column chromatography $(n$ hexane/EtOAc $=10 / 1)$ to give $\mathbf{1 3}(3.47 \mathrm{~g}, 9.96 \mathrm{mmol}, 87 \%)$ as a colorless oil.

${ }^{1}$ H-NMR $\left(\mathrm{CDCl}_{3}, 400 \mathrm{MHz}\right) \delta: 7.28(2 \mathrm{H}, \mathrm{d}, J=8.7 \mathrm{~Hz}), 6.88(2 \mathrm{H}, \mathrm{d}, J=8.7 \mathrm{~Hz}), 5.11(1 \mathrm{H}, \mathrm{d}, J=0.9 \mathrm{~Hz}), 4.94(1 \mathrm{H}$, $\mathrm{d}, J=0.9 \mathrm{~Hz}), 4.63(1 \mathrm{H}, \mathrm{d}, J=10.8 \mathrm{~Hz}), 4.39(1 \mathrm{H}, \mathrm{d}, J=10.8 \mathrm{~Hz}), 4.35(1 \mathrm{H}, \mathrm{dd}, J=11.9,2.7 \mathrm{~Hz}), 4.25(1 \mathrm{H}, \mathrm{dd}, J$ $=11.9,5.0 \mathrm{~Hz}), 3.99(1 \mathrm{H}, \mathrm{m}), 3.80(3 \mathrm{H}, \mathrm{s}), 3.79(1 \mathrm{H}, \mathrm{m}), 3.43-3.37(2 \mathrm{H}, \mathrm{m}), 2.40-2.29(2 \mathrm{H}, \mathrm{m}), 1.21(9 \mathrm{H}, \mathrm{s}) .{ }^{13} \mathrm{C}-$ NMR $\left(\mathrm{CDCl}_{3}, 125 \mathrm{MHz}\right) \delta ; 27.1,35.1,38.8,55.2,63.4,68.5,72.5,79.9,107.2,113.8,113.9,129.6,129.8,143.9$, 159.3, 178.2. HRMS (MALDI-TOF) $m / z 371.1829$ (calcd for $\mathrm{C}_{20} \mathrm{H}_{28} \mathrm{O}_{5} \mathrm{Na}[\mathrm{M}+\mathrm{Na}]^{+}, 371.1826$ ). $[\alpha]^{23} \mathrm{D}=+130.9$ (c $\left.0.09, \mathrm{CHCl}_{3}\right)$.

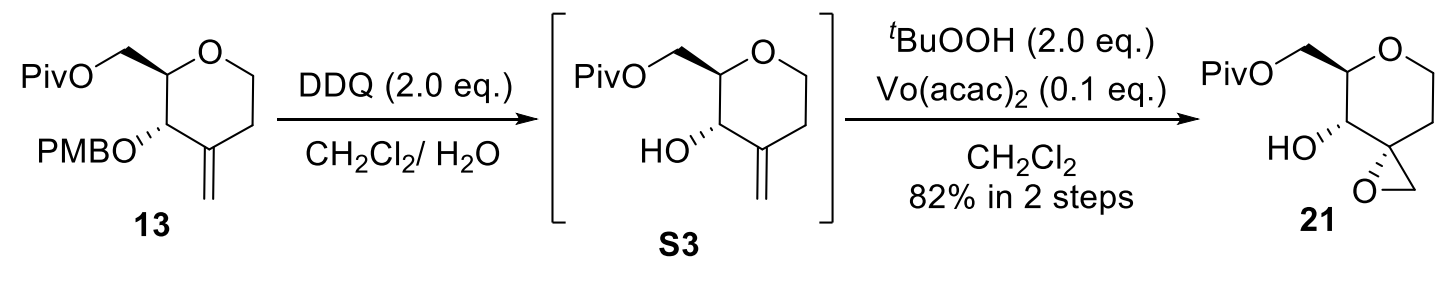

SI - 4 


\section{Compound 21}

(Step 1): To a solution of $\mathbf{1 3}$ (3.47 g, $9.96 \mathrm{mmol}, 1.0$ equiv.) in $\mathrm{CH}_{2} \mathrm{Cl}_{2} / \mathrm{H}_{2} \mathrm{O}(10: 1,100 \mathrm{ml})$ was added DDQ (4.52 g, 19.9 mmol, 2.0 equiv.) at room temperature. After stirring for $14 \mathrm{~h}$, the reaction mixture was quenched with saturated $\mathrm{NaHCO}_{3}$ aq and saturated $\mathrm{Na}_{2} \mathrm{~S}_{2} \mathrm{O}_{3}$ aq. The organic compounds were extracted with $\mathrm{CH}_{2} \mathrm{Cl}_{2}$. The organic layers were combined, and the solution was dried over anhydrous $\mathrm{Na}_{2} \mathrm{SO}_{4}$, and concentrated under reduced pressure. The residue was passed through a short silica gel column $(n$-hexane/EtOAc $=3 / 1)$ to give the crude $\mathbf{S 3}$.

(Step 2): To a solution of $\mathbf{S 3}$ in dry $\mathrm{CH}_{2} \mathrm{Cl}_{2}\left(97 \mathrm{ml}\right.$ ) were added ${ }^{t} \mathrm{BuOOH}$ (5.5 $\mathrm{M}$ in decane solution) (3.5 ml, 19.4 mmol, 2.0 equiv.) and $\mathrm{VO}(\mathrm{acac})_{2}(257 \mathrm{mg}, 0.969 \mathrm{mmol}, 0.1$ equiv.) at room temperature. After stirring for $4 \mathrm{~h}$, the reaction mixture was quenched with saturated $\mathrm{NaHCO}_{3}$ aq and saturated $\mathrm{Na}_{2} \mathrm{~S}_{2} \mathrm{O}_{3}$ aq. The organic compounds were extracted with $\mathrm{CH}_{2} \mathrm{Cl}_{2}$. The organic layers were combined, and the solution was dried over anhydrous $\mathrm{Na}_{2} \mathrm{SO}_{4}$, and concentrated under reduced pressure. The residue was purified by silica gel column chromatography $(n$ hexane/EtOAc $=2 / 1)$ to give $21(2.01 \mathrm{~g}, 8.23 \mathrm{mmol}, 82 \%$ in 2 steps $)$ as a colorless oil.

${ }^{1} \mathbf{H}-\mathbf{N M R}\left(\mathrm{CDCl}_{3}, 400 \mathrm{MHz}\right) \delta: 4.41(1 \mathrm{H}, \mathrm{dd}, J=11.9,4.1 \mathrm{~Hz}), 4.31(1 \mathrm{H}, \mathrm{dd}, J=11.9,5.0 \mathrm{~Hz}), 3.98(1 \mathrm{H}, \mathrm{dd}, J=$ 10.5, 4.6 Hz), 3.74-3.63 (2H, m), $3.43(1 \mathrm{H}, \mathrm{ddd}, J=7.4,5.0,2.3 \mathrm{~Hz}), 3.15(1 \mathrm{H}, \mathrm{d}, J=4.4 \mathrm{~Hz}), 2.65(1 \mathrm{H}, \mathrm{d}, J=4.4$ Hz), $2.32(1 \mathrm{H}, \mathrm{m}), 1.99(1 \mathrm{H}, \mathrm{d}, J=10.5 \mathrm{~Hz}), 1.40(1 \mathrm{H}, \mathrm{m}), 1.23(9 \mathrm{H}, \mathrm{s}) .{ }^{13} \mathbf{C}-\mathbf{N M R}\left(\mathrm{CDCl}_{3}, 125 \mathrm{MHz}\right) \delta ; 27.1,32.9$, 38.8, 49.5, 58.3, 63.9, 64.8, 65.0, 78.9, 178.6. HRMS (MALDI-TOF) $m / z 267.1203$ (calcd for $\mathrm{C}_{12} \mathrm{H}_{20} \mathrm{O}_{5} \mathrm{Na}[\mathrm{M}+\mathrm{Na}]^{+}$, 267.1204). $[\alpha]^{23}{ }_{\mathrm{D}}=+30.2\left(\mathrm{c} 0.19, \mathrm{CHCl}_{3}\right)$.

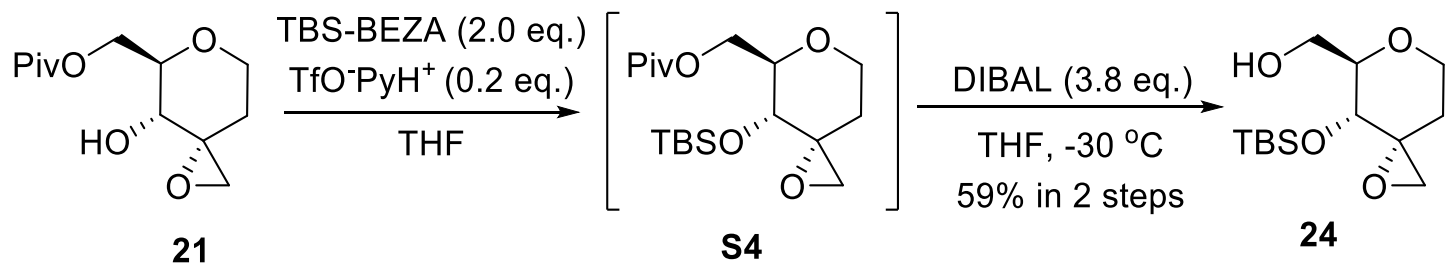

\section{Compound 24}

(Step 1): To a solution of 21 (857 mg, $3.51 \mathrm{mmol}, 1.0$ equiv.) in dry THF ( $8.0 \mathrm{ml})$ was added TBS-BEZA (2.19 g, $7.03 \mathrm{mmol}, 2.0$ equiv.) and $\mathrm{TfO}^{-} \mathrm{PyH}^{+}(174 \mathrm{mg}, 0.759 \mathrm{mmol}, 0.2$ equiv. $)$ at room temperature. After stirring for $15 \mathrm{~h}$, the reaction mixture was quenched with saturated $\mathrm{NaHCO}_{3}$ aq. The organic compounds were extracted with EtOAc. The organic layers were combined, and the solution was dried over anhydrous $\mathrm{Na}_{2} \mathrm{SO}_{4}$, and concentrated under reduced pressure. The residue was passed through a short silica gel column $(n$-hexane/EtOAc $=10 / 1$ to $5 / 1)$ to give the crude $\mathbf{S 4}$ (1.01 g, $2.82 \mathrm{mmol})$.

(Step 2): To a solution of $\mathbf{S 4}(1.01 \mathrm{~g}, 2.82 \mathrm{mmol}, 1.0$ equiv.) in dry THF (15 ml) was added DIBAL (1M toluene solution) (10.7 ml, $10.7 \mathrm{mmol}, 3.8$ equiv.) at $-30^{\circ} \mathrm{C}$. After stirring for $4 \mathrm{~h}$, the reaction mixture was quenched with $\mathrm{MeOH}$ and saturated potassium sodium tartrate aq. The organic compounds were extracted with EtOAc. The organic layers were combined, and the solution was dried over anhydrous $\mathrm{Na}_{2} \mathrm{SO}_{4}$, and concentrated under reduced pressure. 
The residue was purified by silica gel column chromatography ( $n$-hexane/EtOAc $=3 / 1$ to $2 / 1$ ) to give $\mathbf{2 4}$ (567 $\mathrm{mg}$, $2.07 \mathrm{mmol}, 59 \%$ in 2 steps) as a colorless oil.

${ }^{1} \mathrm{H}-\mathrm{NMR}\left(\mathrm{CDCl}_{3}, 300 \mathrm{MHz}\right) \delta: 3.96(1 \mathrm{H}, \mathrm{ddd}, J=11.4,5.5,1.4 \mathrm{~Hz}), 3.84(1 \mathrm{H}, \mathrm{d}, J=9.2 \mathrm{~Hz}), 3.84-3.74(2 \mathrm{H}, \mathrm{m})$, $3.64(1 \mathrm{H}, \mathrm{ddd}, J=7.4,6.9,5.0 \mathrm{~Hz}), 3.54(1 \mathrm{H}, \mathrm{ddd}, J=7.4,5.0,2.8 \mathrm{~Hz}), 3.06(1 \mathrm{H}, \mathrm{d}, J=5.0 \mathrm{~Hz}), 2.59(1 \mathrm{H}, \mathrm{d}, J=5.0$ Hz), $2.22(1 \mathrm{H}$, ddd, $J=13.7,12.4,5.5 \mathrm{~Hz}), 1.94(1 \mathrm{H}, \mathrm{t}, J=6.4 \mathrm{~Hz}), 1.34(1 \mathrm{H}$, ddd, $J=13.7,2.3,1.4 \mathrm{~Hz}), 0.89(9 \mathrm{H}$, s), $0.11(3 \mathrm{H}, \mathrm{s}), 0.06(3 \mathrm{H}, \mathrm{s}) .{ }^{13} \mathbf{C}-\mathbf{N M R}\left(\mathrm{CDCl}_{3}, 125 \mathrm{MHz}\right) \delta$; -4.76, -4.57, 18.0, 25.7, 33.9, 50.1, 59.3, 62.0, 65.1, 66.2, 79.9. HRMS (MALDI-TOF) $\mathrm{m} / \mathrm{z} 297.1493$ (calcd for $\mathrm{C}_{13} \mathrm{H}_{26} \mathrm{O}_{4} \mathrm{SiNa}[\mathrm{M}+\mathrm{Na}]^{+}, 297.1493$ ). $[\alpha]^{23} \mathrm{D}=+68.2(\mathrm{c}$ $\left.0.15, \mathrm{CHCl}_{3}\right)$.

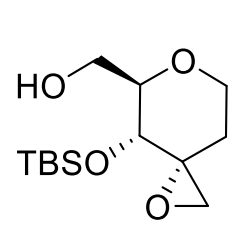

24

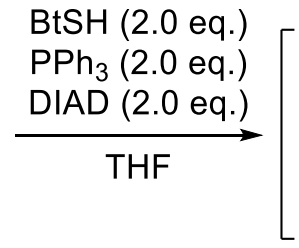

L

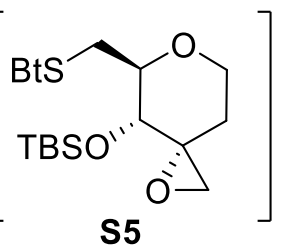

S5

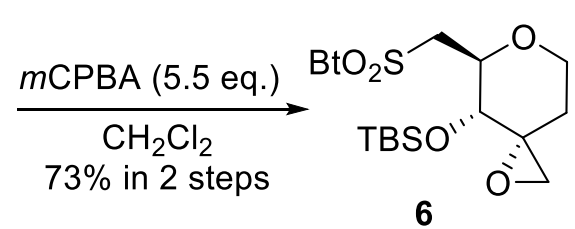

6

\section{Compound 6}

(Step 1): To a solution of 27 (214 mg, $0.780 \mathrm{mmol}, 1.0$ equiv.) in dry THF (5.2 ml) was added BtSH (260 mg, 1.55 mmol, 2.0 equiv.), $\mathrm{PPh}_{3}$ (409 mg, $1.56 \mathrm{mmol}, 2.0$ equiv.) and DIAD ( $0.3 \mathrm{ml}, 1.56 \mathrm{mmol}, 2.0$ equiv.) at $0^{\circ} \mathrm{C}$, and then the reaction mixture was warmed to room temperature. After stirring for $2 \mathrm{~h}$, the reaction mixture was quenched with $\mathrm{H}_{2} \mathrm{O}$. The organic compounds were extracted with EtOAc. The organic layers were combined, and the solution was dried over anhydrous $\mathrm{Na}_{2} \mathrm{SO}_{4}$, and concentrated under reduced pressure. The residue was passed through a short silica gel column $(n$-hexane/EtOAc $=20 / 1$ to $10 / 1)$ to give the crude $\mathbf{S 5}$.

(Step 2): To a solution of above $\mathbf{S 5}$ in dry $\mathrm{CH}_{2} \mathrm{Cl}_{2}(3.2 \mathrm{ml})$ was added $m$-CPBA (740 $\mathrm{mg}, 4.29 \mathrm{mmol}, 5.5$ equiv.) at room temperature. After stirring for $18 \mathrm{~h}$, the reaction mixture was quenched with saturated $\mathrm{NaHCO}_{3}$ aq and saturated $\mathrm{Na}_{2} \mathrm{~S}_{2} \mathrm{O}_{3}$ aq. The organic compounds were extracted with $\mathrm{CH}_{2} \mathrm{Cl}_{2}$. The organic layers were combined, and the solution was dried over anhydrous $\mathrm{Na}_{2} \mathrm{SO}_{4}$, and concentrated under reduced pressure. The residue was purified by silica gel column chromatography ( $n$-hexane/EtOAc $=3 / 1)$ to give $6(250 \mathrm{mg}, 0.569 \mathrm{mmol}, 73 \%$ in 2 steps $)$ as a white solid (mp $150-152^{\circ} \mathrm{C}$ ).

${ }^{1} \mathbf{H}-\mathbf{N M R}\left(\mathrm{CDCl}_{3}, 400 \mathrm{MHz}\right) \delta: 8.20(1 \mathrm{H}, \mathrm{dd}, J=7.8,0.9 \mathrm{~Hz}), 8.00(1 \mathrm{H}, \mathrm{dd}, J=7.8,1.8 \mathrm{~Hz}), 7.64-7.55$ (2H, m), 4.17 $(1 \mathrm{H}, \mathrm{ddd}, J=10.1,8.7,2.3 \mathrm{~Hz}), 3.83(1 \mathrm{H}, \mathrm{ddd}, J=14.6,2.3 \mathrm{~Hz}), 3.73(1 \mathrm{H}, \mathrm{ddd}, J=14.6,10.1 \mathrm{~Hz}), 3.67(1 \mathrm{H}, \mathrm{d}, J=$ $8.7 \mathrm{~Hz}), 3.66(1 \mathrm{H}, \mathrm{m}), 3.56(1 \mathrm{H}, \mathrm{ddd}, J=11.4,6.0,2.1 \mathrm{~Hz}), 3.00(1 \mathrm{H}, \mathrm{d}, J=4.8 \mathrm{~Hz}), 2.57(1 \mathrm{H}, \mathrm{d}, J=4.8 \mathrm{~Hz}), 2.06$ $(1 \mathrm{H}, \mathrm{ddd}, J=14.0,11.9,6.0 \mathrm{~Hz}), 1.31(1 \mathrm{H}, \mathrm{ddd}, J=14.0,2.3,2.1 \mathrm{~Hz}), 0.90(9 \mathrm{H}, \mathrm{s}), 0.12(3 \mathrm{H}, \mathrm{s}), 0.06(3 \mathrm{H}, \mathrm{s}) .{ }^{13} \mathrm{C}-$ NMR $\left(\mathrm{CDCl}_{3}, 100 \mathrm{MHz}\right) \delta ;-4.5,-4.2,17.9,25.6,33.2,50.2,56.9,58.6,64.9,69.0,75.2,122.2,125.3,127.3,127.8$, 136.8, 152.5, 170.0. HRMS (MALDI-TOF) $m / z 478.1147$ (calcd for $\mathrm{C}_{20} \mathrm{H}_{29} \mathrm{NO}_{5} \mathrm{SiNaS}_{2}[\mathrm{M}+\mathrm{Na}]^{+}, 478.1149$ ). $[\alpha]^{23} \mathrm{D}$ $=+24.9\left(\mathrm{c} 0.19, \mathrm{CHCl}_{3}\right)$. 
Preparation and data for 12 : See reference 2.
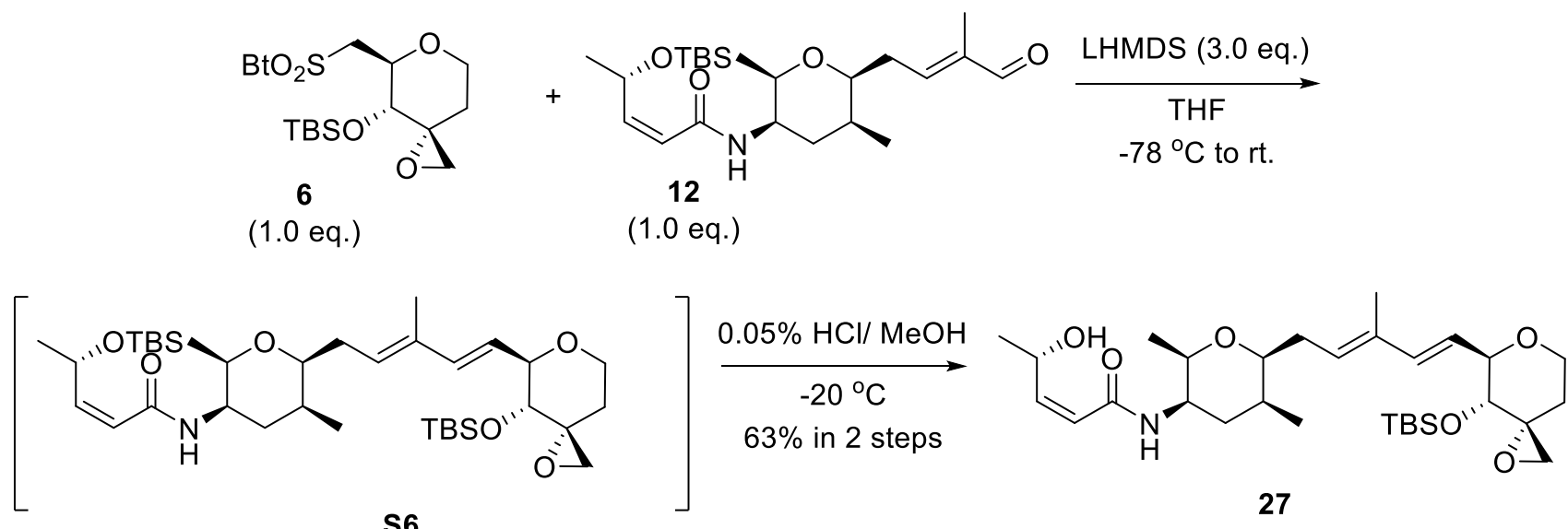

\section{Compound 27}

(Step 1): To a solution of $\mathbf{6}(99.0 \mathrm{mg}, 0.234 \mathrm{mmol}, 1.0$ equiv.) and 12 (107 mg, $0.243 \mathrm{mmol}, 1.0$ equiv.) in dry THF $(1.5 \mathrm{ml})$ was added LHMDS (1M THF solution) $\left(0.7 \mathrm{ml}, 0.700 \mathrm{mmol}, 3.0\right.$ equiv.) at $-78^{\circ} \mathrm{C}$ for $10 \mathrm{~min}$. Then, the reaction mixture was warm to room temperature. After stirring for $18 \mathrm{~h}$, the reaction mixture was quenched with saturated $\mathrm{NH}_{4} \mathrm{Cl}$ aq. The organic compounds were extracted with EtOAc. The organic layers were combined, and the solution was dried over anhydrous $\mathrm{Na}_{2} \mathrm{SO}_{4}$, and concentrated under reduced pressure. The residue was passed through a short silica gel column ( $n$-hexane/ EtOAc $=5 / 1)$ to give the crude $\mathbf{S 6}(136 \mathrm{mg}, 0.205 \mathrm{mmol})$.

(Step 2): To $\mathbf{S 6}(136 \mathrm{mg}, 0.205 \mathrm{mmol})$ was added $0.05 \% \mathrm{HCl} / \mathrm{MeOH}(1.5 \mathrm{ml})$ at $-20{ }^{\circ} \mathrm{C}$. After stirring for $13 \mathrm{~h}$, the reaction mixture was quenched with saturated $\mathrm{NaHCO}_{3}$ aq. The organic compounds were extracted with EtOAc. The organic layers were combined, and the solution was dried over anhydrous $\mathrm{Na}_{2} \mathrm{SO}_{4}$, and concentrated under reduced pressure. The residue was purified by silica gel column chromatography $(n$-hexane/EtOAc $=1 / 1)$ to give $27(81.6$ $\mathrm{mg}, 0.148 \mathrm{mmol}, 63 \%$ in 2 steps) as a colorless amorphous solid.

${ }^{1} \mathrm{H}-\mathrm{NMR}\left(\mathrm{CDCl}_{3}, 400 \mathrm{MHz}\right) \delta: 6.20(1 \mathrm{H}, \mathrm{d}, J=15.6 \mathrm{~Hz}), 6.18(1 \mathrm{H}, \mathrm{dd}, J=11.9,5.5 \mathrm{~Hz}), 5.90(1 \mathrm{H}, \mathrm{d}, J=8.7 \mathrm{~Hz})$, $5.71(1 \mathrm{H}, \mathrm{d}, J=11.9 \mathrm{~Hz}), 5.57(1 \mathrm{H}, \mathrm{d}, J=4.6 \mathrm{~Hz}), 5.53(1 \mathrm{H}, \mathrm{dd}, J=15.6,7.3 \mathrm{~Hz}), 5.45(1 \mathrm{H}, \mathrm{t}, J=6.6 \mathrm{~Hz}), 4.77(1 \mathrm{H}$, m), 4.01-3.93 (3H, m), $3.79(1 \mathrm{H}, \mathrm{m}), 3.65(2 \mathrm{H}, \mathrm{d}, J=8.7 \mathrm{~Hz}), 3.53(1 \mathrm{H}, \mathrm{m}), 3.06(1 \mathrm{H}, \mathrm{d}, J=5.0 \mathrm{~Hz}), 2.60(1 \mathrm{H}, \mathrm{d}, J$ $=5.0 \mathrm{~Hz}), 2.37(1 \mathrm{H}, \mathrm{m}), 2.28-2.20(2 \mathrm{H}, \mathrm{m}), 1.94(1 \mathrm{H}, \mathrm{m}), 1.79-1.73(2 \mathrm{H}, \mathrm{m}), 1.75(3 \mathrm{H}, \mathrm{s}), 1.37(1 \mathrm{H}, \mathrm{m}), 1.35(3 \mathrm{H}$, $\mathrm{d}, J=6.9 \mathrm{~Hz}), 1.13(3 \mathrm{H}, \mathrm{d}, J=6.4 \mathrm{~Hz}), 1.00(3 \mathrm{H}, \mathrm{d}, J=6.8 \mathrm{~Hz}), 0.84(9 \mathrm{H}, \mathrm{s}), 0.02(3 \mathrm{H}, \mathrm{s}),-0.03(3 \mathrm{H}, \mathrm{s}),{ }^{13} \mathbf{C}-\mathbf{N M R}$ $\left(\mathrm{CDCl}_{3}, 125 \mathrm{MHz}\right) \delta$; -4.4, -4.2, 12.5, 15.1, 17.8, 18.0, 22.7, 25.7, 28.8, 31.8, 34.0, 35.7, 47.5, 50.3, 59.4, 64.5, 65.0, $70.4,75.8,80.9,81.5,122.5,124.5,128.6,134.5,138.2,150.7,166.1$. HRMS (MALDI-TOF) $\mathrm{m} / \mathrm{z} 572.3382$ (calcd for $\left.\mathrm{C}_{30} \mathrm{H}_{51} \mathrm{NO}_{6} \mathrm{SiNa}[\mathrm{M}+\mathrm{Na}]^{+}, 572.3378\right) .[\alpha]^{23} \mathrm{D}=+14.3\left(\mathrm{c} 0.03, \mathrm{CHCl}_{3}\right)$. 

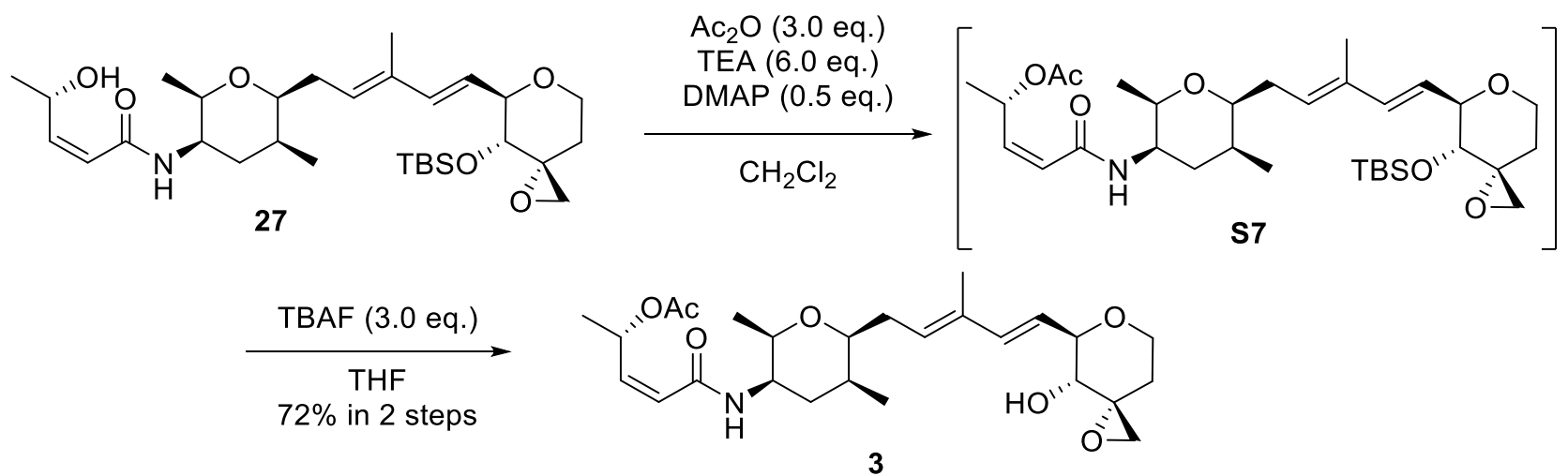

\section{Compound 3}

(Step 1): To a solution of 27 (158 mg, $0.288 \mathrm{mmol}, 1.0$ equiv.) in dry $\mathrm{CH}_{2} \mathrm{Cl}_{2}(3.0 \mathrm{ml})$ was added TEA (200 $\mu 1,1.64$ mmol, 6.0 equiv.), DMAP (18.0 mg, 0.144. mmol, 0.5 equiv.) then $\mathrm{Ac}_{2} \mathrm{O}(90 \mu 1,0.862 \mathrm{mmol}, 3.0$ equiv.) at room temperature. After stirring for $3.5 \mathrm{~h}$, the reaction mixture was quenched with $\mathrm{H}_{2} \mathrm{O}$. The organic compounds were extracted with $\mathrm{CH}_{2} \mathrm{Cl}_{2}$. The organic layers were combined, and the solution was dried over anhydrous $\mathrm{Na}_{2} \mathrm{SO}_{4}$, and concentrated under reduced pressure. The residue was passed through a short silica gel column $(n$-hexane/EtOAc $=$ 5/1) to give the crude $\mathbf{S} 7$ (165 $\mathrm{mg}, 0.278 \mathrm{mmol})$.

(Step 2): To a solution of $\mathbf{S} 7$ (165 $\mathrm{mg}, 0.278 \mathrm{mmol})$ in dry THF (1.0 ml) was added TBAF (1M THF solution) (0.85 $\mathrm{ml}, 0.85 \mathrm{mmol}, 3.0$ equiv.) at room temperature. After stirring for $1.5 \mathrm{~h}$, the reaction mixture was quenched with saturated $\mathrm{NH}_{4} \mathrm{Cl}$ aq. The organic compounds were extracted with EtOAc. The organic layers were combined, and the solution was dried over anhydrous $\mathrm{Na}_{2} \mathrm{SO}_{4}$, and concentrated under reduced pressure. The residue was purified by silica gel column chromatography $(n$-hexane/EtOAc $=1 / 2)$ to give $3(99.0 \mathrm{mg}, 0.207 \mathrm{mmol}, 72 \%$ in 2 steps $)$ as a white solid (mp $\left.72-75^{\circ} \mathrm{C}\right)$.

${ }^{1}$ H-NMR $\left(\mathrm{CDCl}_{3}, 500 \mathrm{MHz}\right) \delta: 6.39(1 \mathrm{H}, \mathrm{d}, J=15.8 \mathrm{~Hz}), 6.25(1 \mathrm{H}, \mathrm{m}), 6.00(1 \mathrm{H}, \mathrm{d}, J=8.9 \mathrm{~Hz}), 5.89(1 \mathrm{H}, \mathrm{dd}, J=$ $11.7,8.1 \mathrm{~Hz}), 5.70(1 \mathrm{H}, \mathrm{dd}, J=11.7,1.2 \mathrm{~Hz}), 5.64(1 \mathrm{H}, \mathrm{dd}, J=15.8,6.0 \mathrm{~Hz}), 5.50(1 \mathrm{H}, \mathrm{t}, J=7.0 \mathrm{~Hz}), 4.01(1 \mathrm{H}, \mathrm{dd}$, $J=11.5,6.0 \mathrm{~Hz}), 3.93(1 \mathrm{H}, \mathrm{m}), 3.79-3.71(2 \mathrm{H}, \mathrm{m}), 3.65(1 \mathrm{H}, \mathrm{dq}, J=6.3,2.0 \mathrm{~Hz}), 3.63(1 \mathrm{H}, \mathrm{m}), 3.51(1 \mathrm{H}, \mathrm{dt}, J=7.2$, $2.9 \mathrm{~Hz}), 3.15(1 \mathrm{H}, \mathrm{d}, J=4.6 \mathrm{~Hz}), 2.65(1 \mathrm{H}, \mathrm{d}, J=4.6 \mathrm{~Hz}), 2.41-2.31(2 \mathrm{H}, \mathrm{m}), 2.23(1 \mathrm{H}, \mathrm{m}), 2.03(3 \mathrm{H}, \mathrm{s}), 1.98-1.89$ $(2 \mathrm{H}, \mathrm{m}), 1.80-1.74(2 \mathrm{H}, \mathrm{m}), 1.77(3 \mathrm{H}, \mathrm{s}), 1.42(1 \mathrm{H}, \mathrm{m}), 1.38(3 \mathrm{H}, \mathrm{d}, J=6.6 \mathrm{~Hz}), 1.14(3 \mathrm{H}, \mathrm{d}, J=6.3 \mathrm{~Hz}), 1.01(3 \mathrm{H}$, d, $J=7.2 \mathrm{~Hz}) .{ }^{13} \mathbf{C}-\mathbf{N M R}\left(\mathrm{CDCl}_{3}, 125 \mathrm{MHz}\right) \delta$; 12.6, 15.1, 17.8, 20.0, 21.2, 28.9, 31.9, 33.2, 35.8, 47.1, 49.7, 58.5, 64.9, 68.7, 68.9, 75.9, 80.8, 81.3, 122.5, 124.1, 129.1, 134.6, 138.0, 143.6, 164.8, 170.4. HRMS (MALDI-TOF) $\mathrm{m} / \mathrm{z}$ 500.2618 (calcd for $\left.\mathrm{C}_{26} \mathrm{H}_{39} \mathrm{NO}_{7} \mathrm{Na}[\mathrm{M}+\mathrm{Na}]^{+}, 500.2619\right)$. $[\alpha]^{23} \mathrm{D}=-11.0\left(\mathrm{c} 0.03, \mathrm{CHCl}_{3}\right)$.

Preparation and data for $\mathbf{A}$ from D-glucal : See reference 3.

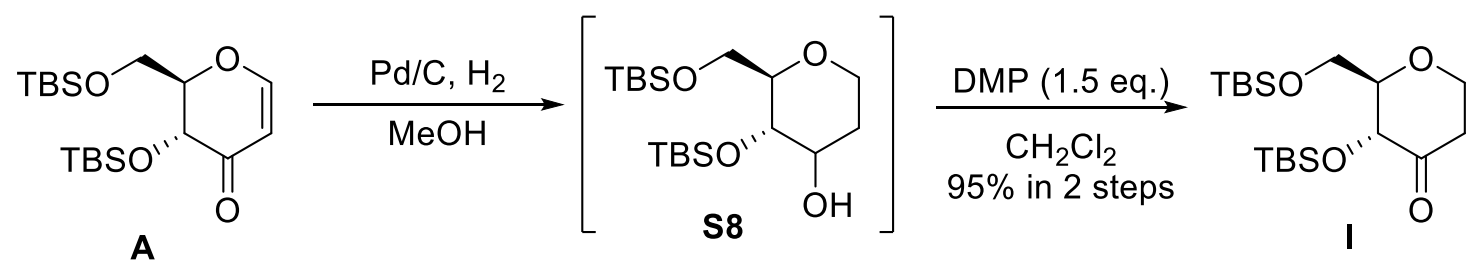




\section{Compound I}

(Step 1): To a solution of A (1.13 g, 2.99 mmol, 1.0 equiv.) in dry $\mathrm{MeOH}(30 \mathrm{ml})$ was added $10 \% \mathrm{Pd} / \mathrm{C}(110 \mathrm{mg}, 10 \%$ $w / w)$ at room temperature. After stirring for $9 \mathrm{~h}$, the reaction mixture was filtered with celite and washed with AcOEt to give the crude $\mathbf{S 8}$.

(Step 2): To a solution of $\mathbf{S 8}$ in dry $\mathrm{CH}_{2} \mathrm{Cl}_{2}(30 \mathrm{ml})$ was added DMP (1.90 g, $4.48 \mathrm{mmol}, 1.2$ equiv.) at room temperature. After stirring for $1 \mathrm{~h}$, the reaction mixture was diluted with $\mathrm{Et}_{2} \mathrm{O}$ and quenched with saturated $\mathrm{NaHCO}_{3}$ aq and saturated $\mathrm{Na}_{2} \mathrm{~S}_{2} \mathrm{O}_{3}$ aq. The organic compounds were extracted with $\mathrm{Et}_{2} \mathrm{O}$. The organic layers were combined, and the solution was dried over anhydrous $\mathrm{Na}_{2} \mathrm{SO}_{4}$, and concentrated under reduced pressure. The residue was passed through a silica gel column $(n$-hexane/EtOAc $=10 / 1)$ to give $\mathbf{x x}(1.18 \mathrm{~g}, 3.15 \mathrm{mmol}, 95 \%$ in 2 steps $)$ as a colorless oil.

${ }^{1} \mathrm{H}-\mathrm{NMR}\left(\mathrm{CDCl}_{3}, 300 \mathrm{MHz}\right) \delta: 4.26-4.20(2 \mathrm{H}, \mathrm{m}), 3.93(1 \mathrm{H}, \mathrm{dd}, J=11.3,1.7 \mathrm{~Hz}), 3.85(1 \mathrm{H}, \mathrm{dd}, J=11.3,4.1 \mathrm{~Hz})$, $3.61(1 \mathrm{H}, \mathrm{m}), 3.40(1 \mathrm{H}, \mathrm{ddd}, J=9.3,3.8,1.7 \mathrm{~Hz}), 2.65(1 \mathrm{H}, \mathrm{m}), 2.41(1 \mathrm{H}, \mathrm{m}), 0.91(9 \mathrm{H}, \mathrm{s}), 0.90(9 \mathrm{H}, \mathrm{s}), 0.17(3 \mathrm{H}$, s), $0.09(3 \mathrm{H}, \mathrm{s}), 0.08(3 \mathrm{H}, \mathrm{s}), 0.03(3 \mathrm{H}, \mathrm{s}) .{ }^{13} \mathbf{C}-\mathbf{N M R}\left(\mathrm{CDCl}_{3}, 125 \mathrm{MHz}\right) \delta$; -5.7, -5.3, -5.0, -4.3, 18.4, 18.5, 25.8, 25.9, $42.1,62.9,66.8,75.1,84.3,206.5$. HRMS (APCA) $m / z 375.2381$ (calcd for $\mathrm{C}_{18} \mathrm{H}_{39} \mathrm{O}_{4} \mathrm{Si}_{2}[\mathrm{M}+\mathrm{H}], 375.2387$ ). $[\alpha]^{23} \mathrm{D}$ $=+62.2\left(\mathrm{c} 0.75, \mathrm{CHCl}_{3}\right)$.
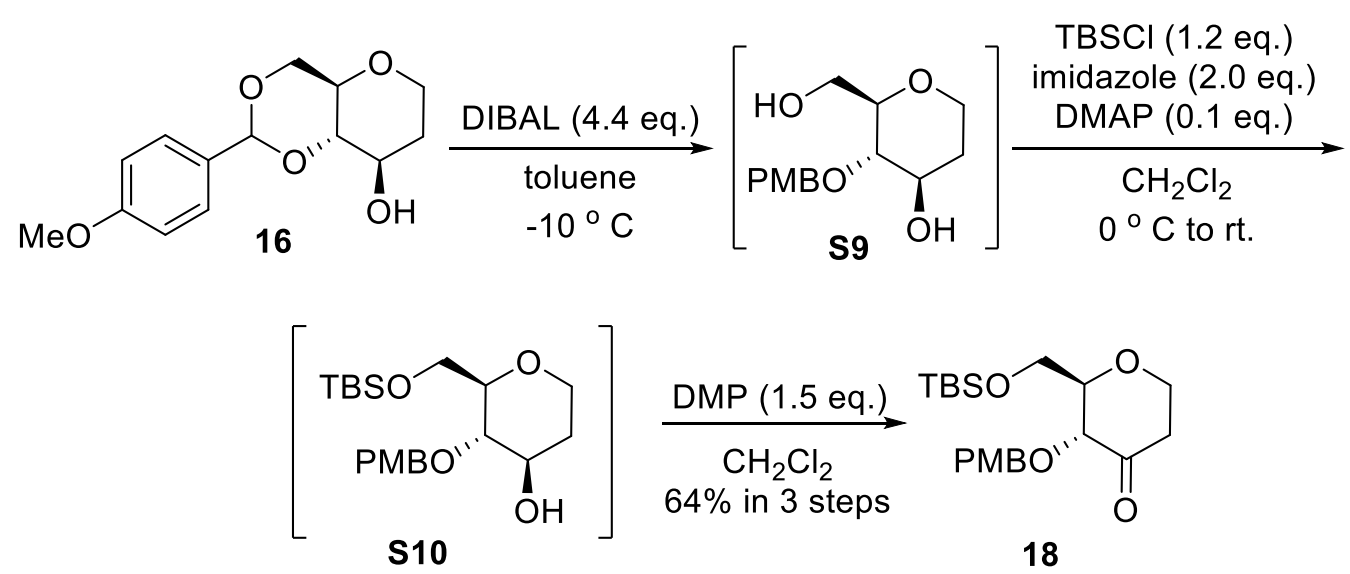

\section{Compound 18}

(Step 1): To a solution of $\mathbf{1 6}$ (600 mg, $2.25 \mathrm{mmol}, 1.0$ equiv.) in dry toluene (22 ml) was added DIBAL (1M toluene solution) (10.0 ml, $10.0 \mathrm{mmol}, 4.4$ equiv.) at $-10{ }^{\circ} \mathrm{C}$. After stirring for $6 \mathrm{~h}$, the reaction mixture was quenched with $\mathrm{MeOH}$ and saturated potassium sodium tartrate aq. The organic compounds were extracted with EtOAc. The organic layers were combined, and the solution was dried over anhydrous $\mathrm{Na}_{2} \mathrm{SO}_{4}$, and concentrated under reduced pressure to give the crude $\mathbf{S 9}$.

(Step 2): To a solution of crude $\mathbf{S 9}$ in dry $\mathrm{CH}_{2} \mathrm{Cl}_{2}(12 \mathrm{ml})$ were added imidazole (306 $\mathrm{mg}, 4.5 \mathrm{mmol}, 2.0$ equiv.), DMAP (29.2 mg, $0.239 \mathrm{mmol}, 0.1$ equiv.) at $0^{\circ} \mathrm{C}$. After stirring for $10 \mathrm{~min}, \mathrm{TBSCl}$ ( $405 \mathrm{mg}, 2.69 \mathrm{mmol}, 1.2$ equiv.) was then added, and then the reaction mixture was warmed to room temperature. After stirring for $1 \mathrm{~h}$, the reaction 
mixture was quenched with saturated $\mathrm{NH}_{4} \mathrm{Cl}$ aq. The organic compounds were extracted with $\mathrm{CH}_{2} \mathrm{Cl}_{2}$. The organic layers were combined, and the solution was dried over anhydrous $\mathrm{Na}_{2} \mathrm{SO}_{4}$, and concentrated under reduced pressure. The residue was purified by short silica gel column chromatography $(n$-hexane/EtOAc $=2 / 1)$ to give crude $\mathbf{S 1 0}(560$ $\mathrm{mg}, 1.46 \mathrm{mmol}$ ) as a colorless oil.

(Step 3): To a solution of crude $\mathbf{S 1 0}$ (560 mg, $1.46 \mathrm{mmol}, 1.0$ equiv.) in dry $\mathrm{CH}_{2} \mathrm{Cl}_{2}$ (10 ml) was added DMP (929 $\mathrm{mg}, 2.19 \mathrm{mmol}, 1.5$ equiv.) at room temperature. After stirring for $2 \mathrm{~h}$, the reaction mixture was diluted with $\mathrm{Et}_{2} \mathrm{O}$ and quenched with saturated $\mathrm{NaHCO}_{3}$ aq and saturated $\mathrm{Na}_{2} \mathrm{~S}_{2} \mathrm{O}_{3}$ aq. The organic compounds were extracted with $\mathrm{Et}_{2} \mathrm{O}$. The organic layers were combined, and the solution was dried over anhydrous $\mathrm{Na}_{2} \mathrm{SO}_{4}$, and concentrated under reduced pressure. The residue was passed through a silica gel column $(n$-hexane/EtOAc $=5 / 1)$ to give $18(550 \mathrm{mg}$, $1.45 \mathrm{mmol}, 64 \%$ in 3 steps) as a colorless oil.

${ }^{1}$ H-NMR $\left(\mathrm{CDCl}_{3}, 300 \mathrm{MHz}\right) \delta: 7.31(2 \mathrm{H}, \mathrm{d}, J=8.6 \mathrm{~Hz}), 6.87(2 \mathrm{H}, \mathrm{d}, J=8.6 \mathrm{~Hz}), 4.82(1 \mathrm{H}, \mathrm{d}, J=10.7 \mathrm{~Hz}), 4.43$ $(1 \mathrm{H}, \mathrm{d}, J=10.7 \mathrm{~Hz}), 4.25(1 \mathrm{H}, \mathrm{ddd}, J=11.2,9.3,1.1 \mathrm{~Hz}), 4.10(1 \mathrm{H}, \mathrm{d}, J=9.3 \mathrm{~Hz}), 3.90-3.82(2 \mathrm{H}, \mathrm{m}), 3.80(3 \mathrm{H}, \mathrm{s})$, $3.62(1 \mathrm{H}, \mathrm{ddd}, J=12.4,11.2,2.4 \mathrm{~Hz}), 3.49(1 \mathrm{H}, \mathrm{ddd}, J=8.7,3.5,2.1 \mathrm{~Hz}), 2.69(1 \mathrm{H}, \mathrm{m}), 2.44(1 \mathrm{H}, \mathrm{m}), 0.91(9 \mathrm{H}, \mathrm{s})$, 0.09 (6H, s). ${ }^{13} \mathbf{C}-\mathbf{N M R}\left(\mathrm{CDCl}_{3}, 125 \mathrm{MHz}\right) \delta$; -5.4, -5.2, 18.4, 25.9, 42.5, 55.2, 62.7, 66.9, 73.1, 79.5, 82.8, 113.7, 129.7, 129.8, 159.3, 206.6. HRMS (MALDI-TOF) $\mathrm{m} / \mathrm{z} 403.1910$ (calcd for $\mathrm{C}_{20} \mathrm{H}_{32} \mathrm{O}_{5} \mathrm{NaSi}[\mathrm{M}+\mathrm{Na}]^{+}, 403.1911$ ). $[\alpha]^{23}=+94.6\left(\mathrm{c} 0.29, \mathrm{CHCl}_{3}\right)$.

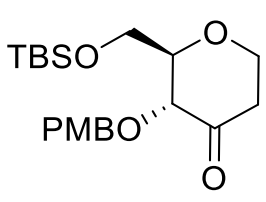

18

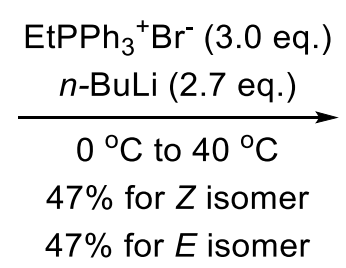

$47 \%$ for $E$ isomer

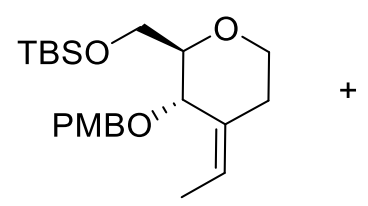

19

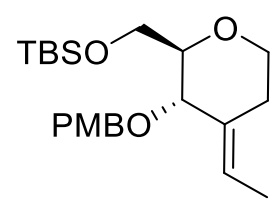

20

\section{Compound 19 and 20}

To a solution of $\mathrm{EtPPh}_{3}{ }^{+} \mathrm{Br}^{-}(1138 \mathrm{mg}, 3.07 \mathrm{mmol}, 3.0$ equiv. $)$ in dry THF $(10 \mathrm{ml})$ was added $n$-BuLi (2.76 M hexane solution) (1.0 ml, $2.76 \mathrm{mmol}, 2.7$ equiv.) at $0{ }^{\circ} \mathrm{C}$. After stirring for $10 \mathrm{~min}$, a solution of $\mathbf{1 8}$ (390 $\mathrm{mg}, 1.02 \mathrm{mmol}, 1.0$ equiv.) in THF $(5.0 \mathrm{ml})$ was then added via syringe, and then the reaction mixture was warmed to $40{ }^{\circ} \mathrm{C}$. After stirring for $2 \mathrm{~h}$, the reaction mixture was quenched with saturated $\mathrm{NH}_{4} \mathrm{Cl}$ aq. The organic compounds were extracted with EtOAc. The organic layers were combined, and the solution was dried over anhydrous $\mathrm{Na}_{2} \mathrm{SO}_{4}$, and concentrated under reduced pressure. The residue was purified by silica gel column chromatography $(n$-hexane/EtOAc $=1 / 0$ to $10 / 1$ to 5/1) to give 19 ( $Z$ isomer) (190 mg, $0.48 \mathrm{mmol}, 47 \%)$ and 20 ( $E$ isomer) (190 mg, $0.48 \mathrm{mmol}, 47 \%)$ as a colorless oil respectively.

19 ( $Z$ isomer): ${ }^{1} \mathbf{H}-\mathbf{N M R}\left(\mathrm{CDCl}_{3}, 400 \mathrm{MHz}\right) \delta: 7.27(2 \mathrm{H}, \mathrm{d}, J=8.7 \mathrm{~Hz}), 6.85(2 \mathrm{H}, \mathrm{d}, J=8.7 \mathrm{~Hz}), 5.64(1 \mathrm{H}, \mathrm{dq}, J=$ 6.9, $1.8 \mathrm{~Hz}), 4.56(1 \mathrm{H}, \mathrm{d}, J=11.9 \mathrm{~Hz}), 4.34(1 \mathrm{H}, \mathrm{m}), 4.30(1 \mathrm{H}, \mathrm{d}, J=11.9 \mathrm{~Hz}), 3.96(1 \mathrm{H}, \mathrm{ddd}, J=7.8,5.5,1.8 \mathrm{~Hz})$, 3.83-3.77 (1H, m), $3.80(3 \mathrm{H}, \mathrm{s}), 3.66-3.62(2 \mathrm{H}, \mathrm{m}), 3.59(1 \mathrm{H}, \mathrm{m}), 2.73(1 \mathrm{H}, \mathrm{m}), 1.91(1 \mathrm{H}, \mathrm{m}), 1.58(3 \mathrm{H}, \mathrm{dd}, J=6.9$, $1.8 \mathrm{~Hz}), 0.89$ (9H, s), $0.02(3 \mathrm{H}, \mathrm{s}), 0.01(3 \mathrm{H}, \mathrm{s}) .{ }^{13} \mathbf{C}-\mathbf{N M R}\left(\mathrm{CDCl}_{3}, 100 \mathrm{MHz}\right) \delta$; -5.6, -5.5, 12.8, 18.0, 25.7, 32.3, 
55.2, 60.7, 64.2, 69.0, 70.5, 78.3, 113.7, 124.4, 129.1, 130.8, 131.4, 159.0. HRMS (MALDI-TOF) $\mathrm{m} / \mathrm{z} 415.2274$ (calcd for $\mathrm{C}_{22} \mathrm{H}_{36} \mathrm{O}_{4} \mathrm{NaSi}[\mathrm{M}+\mathrm{Na}]^{+}$, 415.2275). $[\alpha]^{23} \mathrm{D}=-8.19\left(\mathrm{c} 0.20, \mathrm{CHCl}_{3}\right)$.

20 ( $E$ isomer): ${ }^{1} \mathrm{H}-\mathrm{NMR}\left(\mathrm{CDCl}_{3}, 400 \mathrm{MHz}\right) \delta: 7.27(2 \mathrm{H}, \mathrm{d}, J=8.5 \mathrm{~Hz}), 6.87(2 \mathrm{H}, \mathrm{d}, J=8.5 \mathrm{~Hz}), 5.59$ (1H, q, $J=6.7$ $\mathrm{Hz}), 4.56(1 \mathrm{H}, \mathrm{d}, J=11.0 \mathrm{~Hz}), 4.39(1 \mathrm{H}, \mathrm{d}, J=11.0 \mathrm{~Hz}), 3.88(1 \mathrm{H}, \mathrm{m}), 3.80(3 \mathrm{H}, \mathrm{s}), 3.76(1 \mathrm{H}, \mathrm{d}, J=4.1 \mathrm{~Hz}), 3.79-$ $3.74(2 \mathrm{H}, \mathrm{m}), 3.45(1 \mathrm{H}, \mathrm{dt}, J=10.3,3.2 \mathrm{~Hz}), 3.35(1 \mathrm{H}, \mathrm{dt}, J=7.3,4.1 \mathrm{~Hz}), 2.53(1 \mathrm{H}, \mathrm{dt}, J=14.2,3.4 \mathrm{~Hz}), 2.12(1 \mathrm{H}$, ddd, $J=14.2,10.3,5.0 \mathrm{~Hz}), 1.66(3 \mathrm{H}, \mathrm{d}, J=6.7 \mathrm{~Hz}), 0.89(9 \mathrm{H}, \mathrm{s}), 0.06(6 \mathrm{H}, \mathrm{s}) .{ }^{13} \mathbf{C}-\mathbf{N M R}\left(\mathrm{CDCl}_{3}, 100 \mathrm{MHz}\right) \delta$; $5.3,-5.2,12.5,18.3,25.9,27.7,55.2,62.8,65.5,71.6,77.5,81.9,113.7,117.0,129.4,130.6,133.9,159.1$. HRMS (MALDI-TOF) $m / z 415.2275$ (calcd for $\mathrm{C}_{22} \mathrm{H}_{36} \mathrm{O}_{4} \mathrm{NaSi}[\mathrm{M}+\mathrm{Na}]^{+}, 415.2275$ ). $[\alpha]^{23} \mathrm{D}=+67.4\left(\mathrm{c} 0.17, \mathrm{CHCl}_{3}\right.$ ).

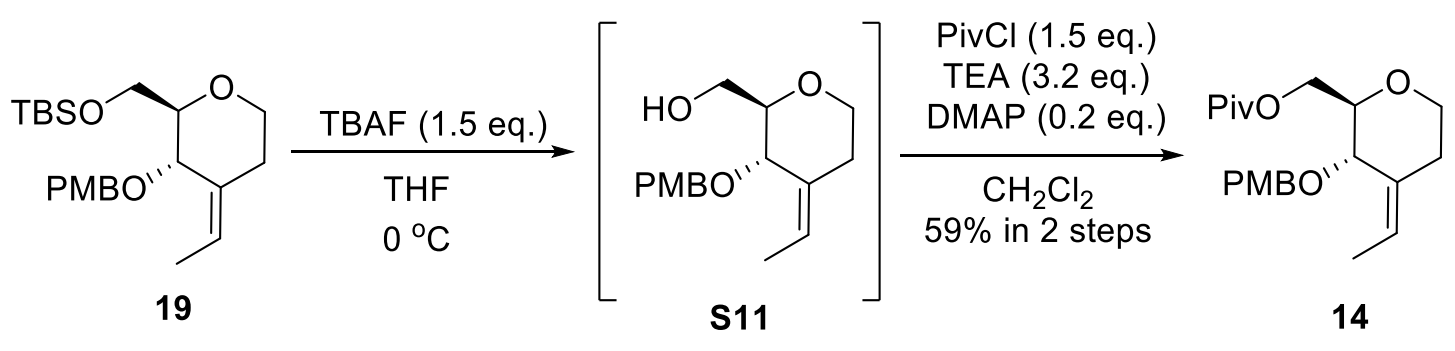

\section{Compound 14}

(Step 1): To a solution of $\mathbf{1 9}$ (1.85 g, $4.71 \mathrm{mmol}, 1.0$ equiv.) in dry THF (23 ml) was added TBAF (1M THF solution) ( $7.0 \mathrm{ml}, 7.00 \mathrm{mmol}, 1.5$ equiv.) at $0{ }^{\circ} \mathrm{C}$. After stirring for $2 \mathrm{~h}$, the reaction mixture was quenched with saturated $\mathrm{NH}_{4} \mathrm{Cl}$ aq. The organic compounds were extracted with EtOAc. The organic layers were combined, and the solution was dried over anhydrous $\mathrm{Na}_{2} \mathrm{SO}_{4}$, and concentrated under reduced pressure. The residue was passed through a short silica gel column ( $n$-hexane/EtOAc $=1 / 1$ to $1 / 2)$ to give the crude $\mathbf{S 1 1}(1.17 \mathrm{~g}, 4.20 \mathrm{mmol})$.

(Step 2): To a solution of $\mathbf{S 1 1}$ (1.17 g, $4.20 \mathrm{mmol}, 1.0$ equiv.) in dry $\mathrm{CH}_{2} \mathrm{Cl}_{2}$ (35 ml) were added TEA (1.33 g, 13.1 mmol, 3.2 equiv.) and DMAP (54.0 mg, $0.44 \mathrm{mmol}, 0.1$ equiv.) and then $\mathrm{PivCl}(790 \mathrm{mg}, 6.55 \mathrm{mmol}, 1.5$ equiv.) at room temperature. After stirring for $1 \mathrm{~h}$, the reaction mixture was quenched with saturated $\mathrm{NH}_{4} \mathrm{Cl}$ aq. The organic compounds were extracted with $\mathrm{CH}_{2} \mathrm{Cl}_{2}$. The organic layers were combined, and the solution was dried over anhydrous $\mathrm{Na}_{2} \mathrm{SO}_{4}$, and concentrated under reduced pressure. The residue was purified by silica gel column chromatography $(n$-hexane/EtOAc $=10 / 1)$ to give $\mathbf{1 4}(1.01 \mathrm{~g}, 2.79 \mathrm{mmol}, 59 \%$ in 2 steps $)$ as a colorless oil.

${ }^{1} \mathrm{H}-\mathrm{NMR}\left(\mathrm{CDCl}_{3}, 300 \mathrm{MHz}\right) \delta: 7.26(2 \mathrm{H}, \mathrm{d}, J=8.7 \mathrm{~Hz}), 6.86(2 \mathrm{H}, \mathrm{d}, J=8.7 \mathrm{~Hz}), 5.67(1 \mathrm{H}, \mathrm{q}, J=6.4 \mathrm{~Hz}), 4.58(1 \mathrm{H}$, d, $J=11.9 \mathrm{~Hz}), 4.26(1 \mathrm{H}, \mathrm{d}, J=11.9 \mathrm{~Hz}), 4.21-4.01(4 \mathrm{H}, \mathrm{m}), 3.83(1 \mathrm{H}, \mathrm{m}), 3.80(3 \mathrm{H}, \mathrm{s}), 3.66(1 \mathrm{H}, \mathrm{dt}, J=11.0,3.2$ $\mathrm{Hz}), 2.75(1 \mathrm{H}, \mathrm{m}), 1.94(1 \mathrm{H}, \mathrm{m}), 1.55(3 \mathrm{H}, \mathrm{d}, J=6.4 \mathrm{~Hz}), 1.13(9 \mathrm{H}, \mathrm{s}),{ }^{13} \mathbf{C}-\mathbf{N M R}\left(\mathrm{CDCl}_{3}, 125 \mathrm{MHz}\right) \delta ; 12.5,26.9$, $32.2,38.5,55.1,61.1,63.9,68.9,70.4,75.5,113.6,124.5,129.1,130.3,130.9,160.0,177.9$. HRMS (MALDI-TOF) $m / z 385.1980$ (calcd for $\left.\mathrm{C}_{21} \mathrm{H}_{30} \mathrm{O} 5 \mathrm{Na}[\mathrm{M}+\mathrm{Na}]^{+}, 385.1986\right)$. $[\alpha]^{23} \mathrm{D}=+21.9\left(\mathrm{c} 0.28, \mathrm{CHCl}_{3}\right)$. 


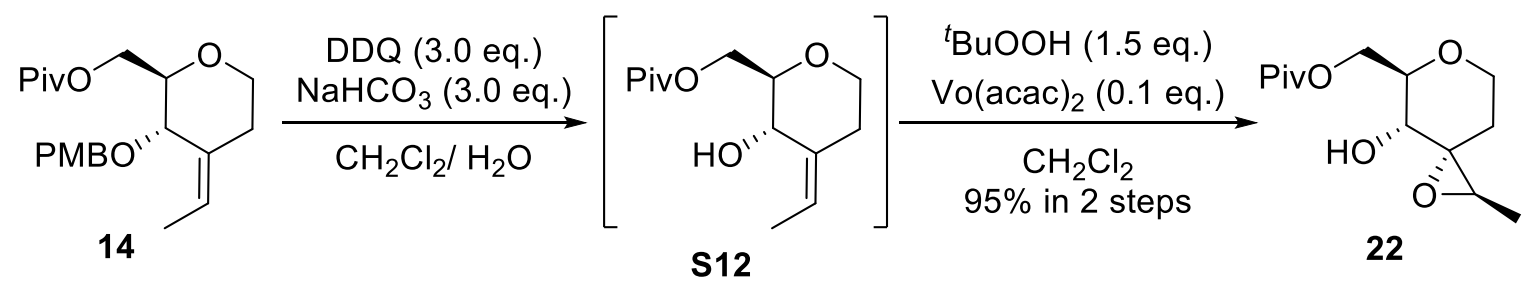

\section{Compound 22}

(Step 1): To a solution of 14 (1.47 g, 4.06 mmol, 1.0 equiv.) in $\mathrm{CH}_{2} \mathrm{Cl}_{2} / \mathrm{H}_{2} \mathrm{O}$ (10 : 1, $40 \mathrm{ml}$ ) was added DDQ (2.76 mg, 12.2 mmol, 3.0 equiv.) and $\mathrm{NaHCO}_{3}(1.02 \mathrm{~g}, 12.1 \mathrm{mmol}, 3.0$ equiv.) at room temperature. After stirring for $2 \mathrm{~h}$, the reaction mixture was quenched with saturated $\mathrm{NaHCO}_{3}$ aq and saturated $\mathrm{Na}_{2} \mathrm{~S}_{2} \mathrm{O}_{3}$ aq. The organic compounds were extracted with $\mathrm{CH}_{2} \mathrm{Cl}_{2}$. The organic layers were combined, and the solution was dried over anhydrous $\mathrm{Na}_{2} \mathrm{SO}_{4}$, and concentrated under reduced pressure. The residue was passed through a short silica gel column ( $n$-hexane/EtOAc $=5 / 1$ to $3 / 1)$ to give the crude $\mathbf{S 1 2}$.

(Step 2): To a solution of $\mathbf{S 1 2}$ in dry $\mathrm{CH}_{2} \mathrm{Cl}_{2}(40 \mathrm{ml})$ were added ${ }^{t} \mathrm{BuOOH}$ (5.5 $\mathrm{M}$ in decane solution) (1.1 ml, 6.05 mmol, 1.5 equiv.) and $\operatorname{Vo}(\mathrm{acac})_{2}(103 \mathrm{mg}, 0.39 \mathrm{mmol}, 0.1$ equiv.) at room temperature. After stirring for $4 \mathrm{~h}$, the reaction mixture was quenched with saturated $\mathrm{NaHCO}_{3}$ aq and saturated $\mathrm{Na}_{2} \mathrm{~S}_{2} \mathrm{O}_{3}$ aq. The organic compounds were extracted with $\mathrm{CH}_{2} \mathrm{Cl}_{2}$. The organic layers were combined, and the solution was dried over anhydrous $\mathrm{Na}_{2} \mathrm{SO}_{4}$, and concentrated under reduced pressure. The residue was purified by silica gel column chromatography $(n-$ hexane/EtOAc = 2/1) to give 22 (996 mg, $3.86 \mathrm{mmol}, 95 \%$ in 2 steps) as a colorless oil.

${ }^{1}$ H-NMR $\left(\mathrm{CDCl}_{3}, 300 \mathrm{MHz}\right) \delta: 4.41(1 \mathrm{H}, \mathrm{dd}, J=11.9,5.3 \mathrm{~Hz}), 4.31(1 \mathrm{H}, \mathrm{dd}, J=11.9,2.1 \mathrm{~Hz}), 3.92(1 \mathrm{H}, \mathrm{ddd}, J=$ 10.2, 5.3, $2.1 \mathrm{~Hz}), 3.76(1 \mathrm{H}, \mathrm{t}, J=10.2 \mathrm{~Hz}), 3.64(1 \mathrm{H}, \mathrm{dt}, J=12.2,2.3 \mathrm{~Hz}), 3.44(1 \mathrm{H}, \mathrm{m}), 2.92(1 \mathrm{H}, \mathrm{q}, J=6.0 \mathrm{~Hz})$, $2.18(1 \mathrm{H}, \mathrm{ddd}, J=14.2,12.2,5.5 \mathrm{~Hz}), 2.05(1 \mathrm{H}, \mathrm{d}, J=10.2 \mathrm{~Hz}), 1.55(3 \mathrm{H}, \mathrm{d}, J=6.0 \mathrm{~Hz}), 1.34(1 \mathrm{H}, \mathrm{m}), 1.22(9 \mathrm{H}$, s), ${ }^{13} \mathbf{C}-\mathbf{N M R}\left(\mathrm{CDCl}_{3}, 125 \mathrm{MHz}\right) \delta ; 13.4,27.0,33.9,38.6,60.7,61.3,63.5,64.3,64.7,79.1,178.3$. HRMS (MALDITOF) $m / z 281.1359$ (calcd for $\left.\mathrm{C}_{13} \mathrm{H}_{22} \mathrm{O}_{5} \mathrm{Na}[\mathrm{M}+\mathrm{Na}]^{+}, 281.1359\right)$. $[\alpha]^{23}=+21.1$ (c $0.32, \mathrm{CHCl}_{3}$ ).

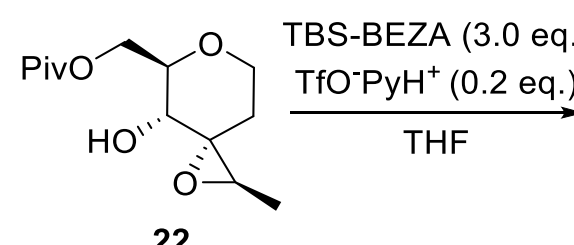

22

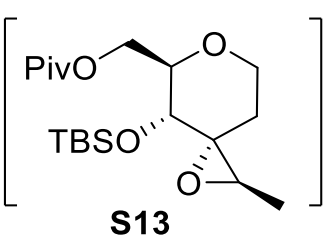

S13

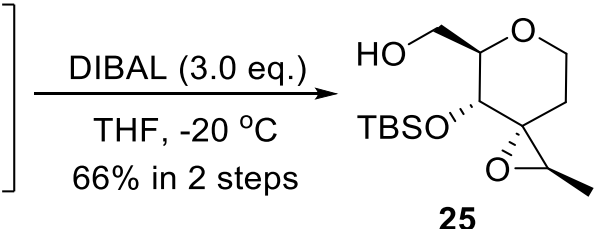

25

\section{Compound 25}

(Step 1): To a solution of 22 (422 mg, $1.63 \mathrm{mmol}, 1.0$ equiv.) in dry THF (8.0 ml) was added TBS-BEZA (1.52 g, $4.88 \mathrm{mmol}, 3.0$ equiv.) and $\mathrm{TfO}^{-} \mathrm{PyH}^{+}$(75.6 mg, $0.33 \mathrm{mmol}, 0.2$ equiv.) at room temperature. After stirring for $6 \mathrm{~h}$, the reaction mixture was quenched with saturated $\mathrm{NaHCO}_{3}$ aq. The organic compounds were extracted with EtOAc. The organic layers were combined, and the solution was dried over anhydrous $\mathrm{Na}_{2} \mathrm{SO}_{4}$, and concentrated under reduced pressure. The residue was passed through a short silica gel column $(n$-hexane/EtOAc $=10 / 1)$ to give the crude S13 (424 mg, $1.14 \mathrm{mmol}$ ). 
(Step 2): To a solution of $\mathbf{S 1 3}$ (424 $\mathrm{mg}, 1.14 \mathrm{mmol}, 1.0$ equiv.) in dry THF (11 ml) was added DIBAL (1M toluene solution) (3.4 ml, $3.40 \mathrm{mmol}, 3.0$ equiv.) at $-20^{\circ} \mathrm{C}$. After stirring for $3 \mathrm{~h}$, the reaction mixture was quenched with saturated potassium sodium tartrate aq. The organic compounds were extracted with EtOAc. The organic layers were combined, and the solution was dried over anhydrous $\mathrm{Na}_{2} \mathrm{SO}_{4}$, and concentrated under reduced pressure. The residue was purified by silica gel column chromatography $(n$-hexane/EtOAc $=2 / 1)$ to give $25(310 \mathrm{mg}, 1.07 \mathrm{mmol}, 66 \%$ in 2 steps) as a colorless oil.

${ }^{1} \mathbf{H}-\mathbf{N M R}\left(\mathrm{CDCl}_{3}, 300 \mathrm{MHz}\right)$ 8: 3.97-3.87 (2H, m), 3.87-3.76 (2H, m), 3.55-3.45 (2H, m), $2.96(1 \mathrm{H}, \mathrm{q}, J=5.5 \mathrm{~Hz})$, $2.64(1 \mathrm{H}, \mathrm{ddd}, J=11.9,11.9,5.9 \mathrm{~Hz}), 1.85(1 \mathrm{H}, \mathrm{dd}, J=8.7,2.3 \mathrm{~Hz}), 1.32(3 \mathrm{H}, \mathrm{d}, J=5.5 \mathrm{~Hz}), 1.01(1 \mathrm{H}, \mathrm{m}), 0.92$ $(9 \mathrm{H}, \mathrm{s}), 0.12(3 \mathrm{H}, \mathrm{s}), 0.09(3 \mathrm{H}, \mathrm{s}) .{ }^{13} \mathrm{C}-\mathrm{NMR}\left(\mathrm{CDCl}_{3}, 125 \mathrm{MHz}\right) \delta ;-4.9,-4.5,14.5,18.1,25.8,30.0,58.9,60.5,61.1$, 61.2, 68.3, 81.4. HRMS (MALDI-TOF) $m / z 311.1643$ (calcd for $\mathrm{C}_{14} \mathrm{H}_{28} \mathrm{O}_{4} \mathrm{NaSi}[\mathrm{M}+\mathrm{Na}]^{+}, 311.1649$ ). $[\alpha]^{23}{ }_{\mathrm{D}}=+25.4$ (c $0.14, \mathrm{CHCl}_{3}$ ).

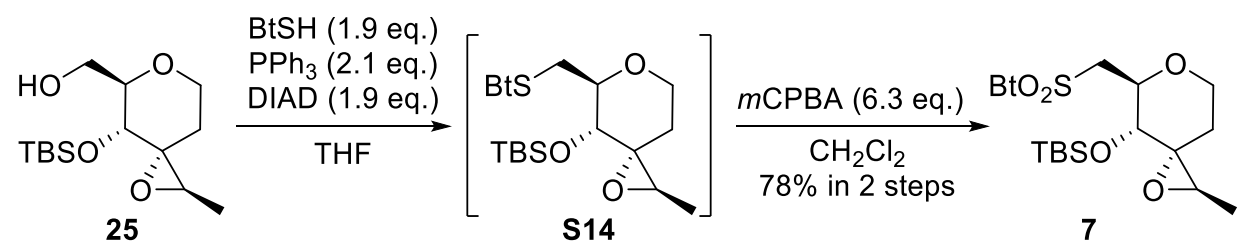

\section{Compound 7}

(Step 1): To a solution of $\mathbf{2 5}$ (30.7 mg, $0.106 \mathrm{mmol}, 1.0$ equiv.) in dry THF $(1.0 \mathrm{ml})$ was added BtSH (34.4 mg, 0.206 mmol, 1.9 equiv.), $\mathrm{PPh}_{3}(57.2 \mathrm{mg}, 0.218 \mathrm{mmol}, 2.1$ equiv.) and DIAD (40 $\mu 1,0.198 \mathrm{mmol}, 1.9$ equiv.) at room temperature. After stirring for $2 \mathrm{~h}$, the reaction mixture was quenched with $\mathrm{H}_{2} \mathrm{O}$. The organic compounds were extracted with EtOAc. The organic layers were combined, and the solution was dried over anhydrous $\mathrm{Na}_{2} \mathrm{SO}_{4}$, and concentrated under reduced pressure. The residue was passed through a short silica gel column $(n$-hexane/EtOAc $=$ 8/1) to give the crude $\mathbf{S 1 4}$.

(Step 2): To a solution of above $\mathbf{S 1 4}$ in dry $\mathrm{CH}_{2} \mathrm{Cl}_{2}(2.0 \mathrm{ml})$ was added $m$-CPBA (115 mg, $0.666 \mathrm{mmol}, 6.3$ equiv.) at room temperature. After stirring for $15 \mathrm{~h}$, the reaction mixture was quenched with saturated $\mathrm{NaHCO}_{3}$ aq and saturated $\mathrm{Na}_{2} \mathrm{~S}_{2} \mathrm{O}_{3}$ aq. The organic compounds were extracted with $\mathrm{CH}_{2} \mathrm{Cl}_{2}$. The organic layers were combined, and the solution was dried over anhydrous $\mathrm{Na}_{2} \mathrm{SO}_{4}$, and concentrated under reduced pressure. The residue was purified by silica gel column chromatography ( $n$-hexane/EtOAc $=5 / 1)$ to give $7(39.0 \mathrm{mg}, 0.083 \mathrm{mmol}, 78 \%$ in 2 steps $)$ as a colorless amorphous solid.

${ }^{1} \mathrm{H}-\mathrm{NMR}\left(\mathrm{CDCl}_{3}, 400 \mathrm{MHz}\right) \delta: 8.20(1 \mathrm{H}, \mathrm{d}, J=7.8 \mathrm{~Hz}), 8.01(1 \mathrm{H}, \mathrm{d}, J=7.8 \mathrm{~Hz}), 7.67-7.58(2 \mathrm{H}, \mathrm{m}), 4.52(1 \mathrm{H}, \mathrm{dd}$, $J=6.4,6.4 \mathrm{~Hz}), 4.08(1 \mathrm{H}, \mathrm{dd}, J=14.7,7.8 \mathrm{~Hz}), 3.60(1 \mathrm{H}, \mathrm{m} \mathrm{Hz}), 3.55(1 \mathrm{H}, \mathrm{m} \mathrm{Hz}), 3.53(1 \mathrm{H}, \mathrm{m} \mathrm{Hz}), 3.43(1 \mathrm{H}, \mathrm{dd}$, $J=14.7,5.5 \mathrm{~Hz}), 3.00(1 \mathrm{H}, \mathrm{q}, J=5.8 \mathrm{~Hz}), 2.57(1 \mathrm{H}, \mathrm{m}), 1.43(3 \mathrm{H}, \mathrm{d}, J=5.8 \mathrm{~Hz}), 0.9(9 \mathrm{H}, \mathrm{s}), 0.88(1 \mathrm{H}, \mathrm{m}), 0.911$ (3H, s), 0.09 (3H, s). ${ }^{13} \mathbf{C}-\mathbf{N M R}\left(\mathrm{CDCl}_{3}, 100 \mathrm{MHz}\right) \delta$; -4.9, -4.6, 14.9, 18.1, 25.7, 29.5, 53.3, 60.2, 60.4, 61.2, 69.9, 74.8, 122.4, 125.3, 127.7, 128.1, 136.8, 152.5, 165.8. HRMS (MALDI-TOF) $\mathrm{m} / \mathrm{z} 492.1307$ (calcd for 
$\left.\mathrm{C}_{21} \mathrm{H}_{31} \mathrm{NO}_{5} \mathrm{NaSiS}_{2}[\mathrm{M}+\mathrm{Na}]^{+}, 492.1305\right) .[\alpha]^{23}{ }_{\mathrm{D}}=-10.2\left(\mathrm{c} 0.18, \mathrm{CHCl}_{3}\right)$.

Preparation and data for $\mathbf{1 3}$ : See reference 4.
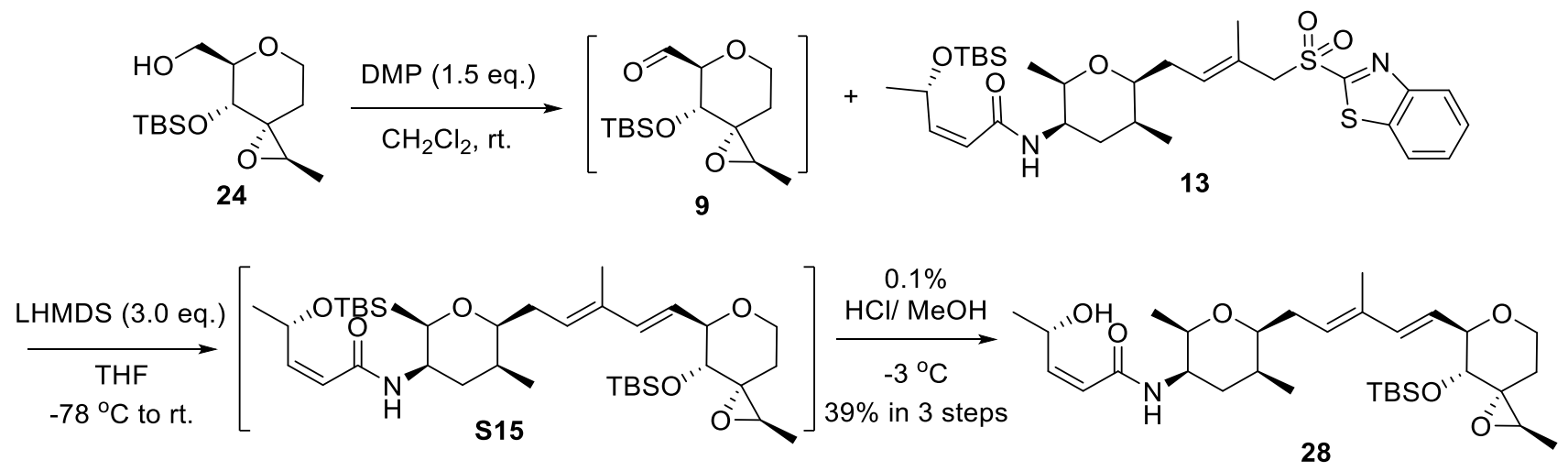

\section{Compound 28}

(Step 1): To a solution of 24 (30.3 mg, $0.105 \mathrm{mmol}, 1.0$ equiv.) in dry $\mathrm{CH}_{2} \mathrm{Cl}_{2}$ (1.0 ml) was added DMP (66.5 mg, $0.157 \mathrm{mmol}, 1.5$ equiv.) at room temperature. After stirring for $1 \mathrm{~h}$, the reaction mixture was diluted with $\mathrm{Et}_{2} \mathrm{O}$ and quenched with saturated $\mathrm{NaHCO}_{3}$ aq and saturated $\mathrm{Na}_{2} \mathrm{~S}_{2} \mathrm{O}_{3}$ aq. The organic compounds were extracted with $\mathrm{Et}_{2} \mathrm{O}$. The organic layers were combined, and the solution was dried over anhydrous $\mathrm{Na}_{2} \mathrm{SO}_{4}$, and concentrated under reduced pressure to give the crude $\mathbf{9}(29.2 \mathrm{mg}, 0.101 \mathrm{mmol})$.

(Step 2): To a solution of 9 (29.2 mg, $0.102 \mathrm{mmol}, 1.0$ equiv.) and 13 (60.3 mg, $0.099 \mathrm{mmol}, 1.0$ equiv.) in dry THF $(1.0 \mathrm{ml})$ was added LHMDS (1M THF solution) $(0.30 \mathrm{ml}, 0.300 \mathrm{mmol}, 3.0$ equiv. $)$ at $-78{ }^{\circ} \mathrm{C}$. After $30 \mathrm{~min}$, the solution was warm to room temperature and stirred for $15 \mathrm{~h}$. The reaction mixture was quenched with saturated $\mathrm{NH}_{4} \mathrm{Cl}$ aq. The organic compounds were extracted with EtOAc. The organic layers were combined, and the solution was dried over anhydrous $\mathrm{Na}_{2} \mathrm{SO}_{4}$, and concentrated under reduced pressure. The residue was passed through a short silica gel column $(n$-hexane/EtOAc $=3 / 1)$ to give the crude $\mathrm{S} 15$.

(Step 3): To $\mathbf{S 1 5}$ was added $0.1 \% \mathrm{HCl} / \mathrm{MeOH}(2.0 \mathrm{ml})$ at $-3{ }^{\circ} \mathrm{C}$. After stirring for $21 \mathrm{~h}$, the reaction mixture was quenched with saturated $\mathrm{NaHCO}_{3}$ aq. The organic compounds were extracted with EtOAc. The organic layers were combined, and the solution was dried over anhydrous $\mathrm{Na}_{2} \mathrm{SO}_{4}$, and concentrated under reduced pressure. The residue was purified by silica gel column chromatography ( $n$-hexane/EtOAc $=1 / 1$ to $4 / 6)$ to give $\mathbf{2 8}(23.1 \mathrm{mg}, 0.041 \mathrm{mmol}$, $39 \%$ in 3 steps) as a colorless amorphous solid.

${ }^{1} \mathrm{H}-\mathrm{NMR}\left(\mathrm{CDCl}_{3}, 500 \mathrm{MHz}\right) \delta: 6.30(1 \mathrm{H}, \mathrm{d}, J=15.8 \mathrm{~Hz}), 6.17(1 \mathrm{H}, \mathrm{dd}, J=12.1,5.5 \mathrm{~Hz}), 5.93(1 \mathrm{H}, \mathrm{d}, J=9.2 \mathrm{~Hz})$, $5.71(1 \mathrm{H}, \mathrm{dd}, J=12.1,1.8 \mathrm{~Hz}), 5.62(1 \mathrm{H}, \mathrm{dd}, J=15.8,6.9 \mathrm{~Hz}), 5.54(1 \mathrm{H}, \mathrm{d}, J=4.6 \mathrm{~Hz}), 5.50(1 \mathrm{H}, \mathrm{t}, J=6.6 \mathrm{~Hz})$, $4.78(1 \mathrm{H}, \mathrm{m}), 4.37(1 \mathrm{H}, \mathrm{d}, J=6.9 \mathrm{~Hz}), 3.93(1 \mathrm{H}, \mathrm{m}), 3.90-3.83(2 \mathrm{H}, \mathrm{m}), 3.67(1 \mathrm{H}, \mathrm{dq}, J=6.3,2.3 \mathrm{~Hz}), 3.54(1 \mathrm{H}, \mathrm{dt}$, $J=7.2,2.6 \mathrm{~Hz}), 3.47(1 \mathrm{H}, \mathrm{m}), 2.95(1 \mathrm{H}, \mathrm{q}, J=5.7 \mathrm{~Hz}), 2.66(1 \mathrm{H}, \mathrm{m}), 2.39(1 \mathrm{H}, \mathrm{m}), 2.24(1 \mathrm{H}, \mathrm{m}), 1.95(2 \mathrm{H}, \mathrm{t}, J=$ $3.5 \mathrm{~Hz}), 1.83-1.74(2 \mathrm{H}, \mathrm{m}), 1.76(3 \mathrm{H}, \mathrm{s}), 1.34(3 \mathrm{H}, \mathrm{d}, J=6.9 \mathrm{~Hz}), 1.30(3 \mathrm{H}, \mathrm{d}, J=5.7 \mathrm{~Hz}), 1.14(3 \mathrm{H}, \mathrm{d}, J=6.3 \mathrm{~Hz})$, $1.01(3 \mathrm{H}, \mathrm{d}, J=7.5 \mathrm{~Hz}), 0.92(9 \mathrm{H}, \mathrm{s}), 0.12(3 \mathrm{H}, \mathrm{s}), 0.08(3 \mathrm{H}, \mathrm{s}) .{ }^{13} \mathbf{C}-\mathbf{N M R}\left(\mathrm{CDCl}_{3}, 125 \mathrm{MHz}\right) \delta ;-4.8,-4.5,12.7$, 
$15.1,15.2,17.8,18.2,22.7,25.8,28.9,30.5,31.9,35.7,47.4,60.5,61.2,61.2,64.6,71.8,75.9,80.8,81.5,121.1$, 122.5, 129.2, 134.4, 138.1, 150.7, 166.1. HRMS (MALDI-TOF) $m / z 586.3534$ (calcd for $\mathrm{C}_{31} \mathrm{H}_{53} \mathrm{NO}_{6} \mathrm{SiNa}[\mathrm{M}+\mathrm{Na}]^{+}$, 586.3534). $[\alpha]^{23}=+33.1\left(\mathrm{c} 0.15, \mathrm{CHCl}_{3}\right)$.

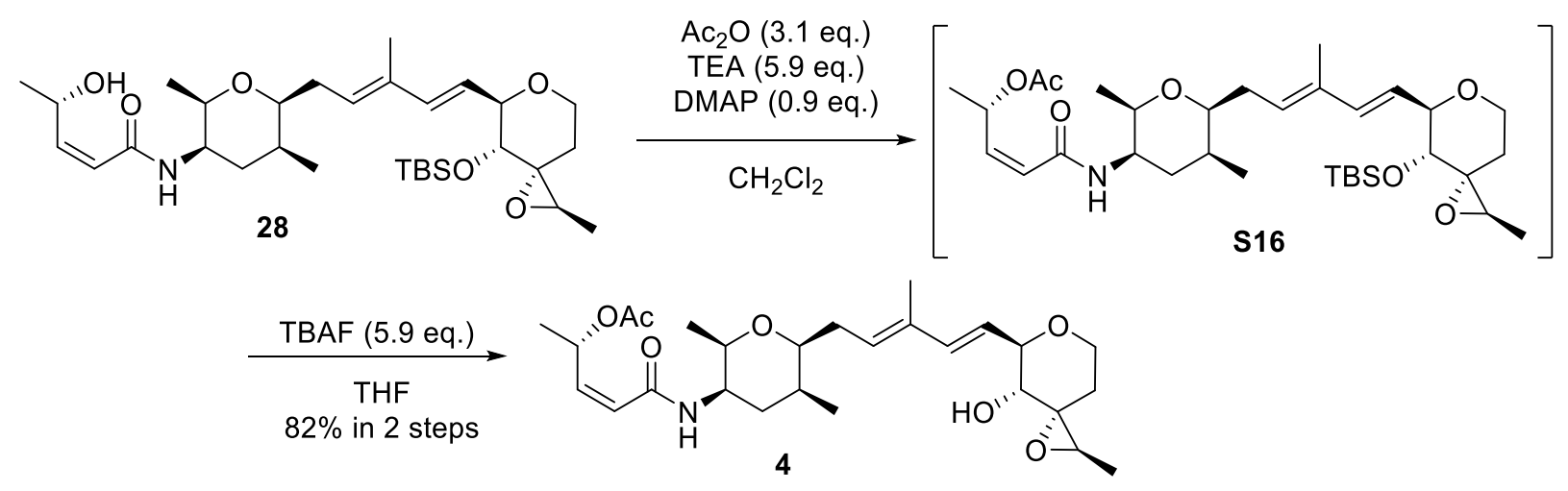

\section{Compound 4}

(Step 1): To a solution of $\mathbf{2 8}\left(12.2 \mathrm{mg}, 0.022 \mathrm{mmol}, 1.0\right.$ equiv.) in dry $\mathrm{CH}_{2} \mathrm{Cl}_{2}(1.0 \mathrm{ml})$ was added TEA (15 $\mu 1,0.129$ mmol, 5.9 equiv.), DMAP (2.5 mg, $0.020 \mathrm{mmol}, 0.9$ equiv.) then $\mathrm{Ac}_{2} \mathrm{O}$ (7 $\mu 1 \mathrm{mg}, 0.068 \mathrm{mmol}, 3.1$ equiv.) at room temperature. After stirring for $1 \mathrm{~h}$, the reaction mixture was quenched with saturated $\mathrm{NH}_{4} \mathrm{Cl}$ aq. The organic compounds were extracted with $\mathrm{CH}_{2} \mathrm{Cl}_{2}$. The organic layers were combined, and the solution was dried over anhydrous $\mathrm{Na}_{2} \mathrm{SO}_{4}$, and concentrated under reduced pressure. The residue was passed through a short silica gel column $(n$-hexane/EtOAc $=1 / 1)$ to give the crude $\mathbf{S 1 6}(13.2 \mathrm{mg}, 0.021 \mathrm{mmol})$.

(Step 2): To a solution of $\mathbf{S 1 6}$ (13.2 mg, $0.022 \mathrm{mmol}, 1.0$ equiv.) in dry THF (1.0 ml) was added TBAF (1M THF solution) $(130 \mu \mathrm{l}, 0.130 \mathrm{mmol}, 5.9$ equiv.) at room temperature. After stirring for $1 \mathrm{~h}$, the reaction mixture was quenched with saturated $\mathrm{NH}_{4} \mathrm{Cl}$ aq. The organic compounds were extracted with EtOAc. The organic layers were combined, and the solution was dried over anhydrous $\mathrm{Na}_{2} \mathrm{SO}_{4}$, and concentrated under reduced pressure. The residue was purified by silica gel column chromatography $(n$-hexane/EtOAc $=1 / 2)$ to give $4(8.7 \mathrm{mg}, 0.018 \mathrm{mmol}, 82 \%$ in 2 steps) as a white solid (mp $\left.96-99^{\circ} \mathrm{C}\right)$.

${ }^{1} \mathrm{H}-\mathrm{NMR}\left(\mathrm{CDCl}_{3}, 500 \mathrm{MHz}\right) \delta: 6.39(1 \mathrm{H}, \mathrm{d}, J=16.1 \mathrm{~Hz}), 6.28(1 \mathrm{H}, \mathrm{m}), 6.02(1 \mathrm{H}, \mathrm{d}, J=9.2 \mathrm{~Hz}), 5.89(1 \mathrm{H}, \mathrm{dd}, J=$ $11.5,7.5 \mathrm{~Hz}), 5.75-5.67(2 \mathrm{H}, \mathrm{m}), 5.50(1 \mathrm{H}, \mathrm{t}, J=7.2 \mathrm{~Hz}), 3.97-3.90(2 \mathrm{H}, \mathrm{m}), 3.81(1 \mathrm{H}, \mathrm{m}), 3.71(1 \mathrm{H}, \mathrm{dt}, J=11.5$, $2.9 \mathrm{~Hz}), 3.68-3.62(2 \mathrm{H}, \mathrm{m}), 3.51(1 \mathrm{H}, \mathrm{dt}, J=6.9,2.9 \mathrm{~Hz}), 2.93(1 \mathrm{H}, \mathrm{q}, J=6.3 \mathrm{~Hz}), 2.38(1 \mathrm{H}, \mathrm{m}), 2.21(1 \mathrm{H}, \mathrm{m}), 2.14$ $(1 \mathrm{H}, \mathrm{m}), 2.04(3 \mathrm{H}, \mathrm{s}), 1.98-1.89(3 \mathrm{H}, \mathrm{m}), 1.79-1.77(1 \mathrm{H}, \mathrm{m}), 1.77(3 \mathrm{H}, \mathrm{s}), 1.53(3 \mathrm{H}, \mathrm{d}, J=6.3 \mathrm{~Hz}), 1.44(1 \mathrm{H}, \mathrm{m})$, $1.38(3 \mathrm{H}, \mathrm{d}, J=6.3 \mathrm{~Hz}), 1.14(3 \mathrm{H}, \mathrm{d}, J=6.3 \mathrm{~Hz}), 1.00(3 \mathrm{H}, \mathrm{d}, J=7.5 \mathrm{~Hz}) .{ }^{13} \mathbf{C}-\mathbf{N M R}\left(\mathrm{CDCl}_{3}, 125 \mathrm{MHz}\right) \delta ; 12.6$, 13.7, 15.0, 17.8, 20.0, 21.2, 28.9, 31.9, 34.1, 35.8, 47.1, 60.9, 61.6, 64.2, 68.6, 68.9, 75.9, 80.8, 81.5, 122.5, 123.8, 129.1, 134.6, 138.2, 143.6, 164.9, 170.4. HRMS (MALDI-TOF) $\mathrm{m} / \mathrm{z} 514.2775$ (calcd for $\mathrm{C}_{27} \mathrm{H}_{41} \mathrm{NO}_{7} \mathrm{Na}[\mathrm{M}+\mathrm{Na}]^{+}$, 514.2775). $[\alpha]^{23}=-33.1\left(\mathrm{c} 0.02, \mathrm{CHCl}_{3}\right)$. 


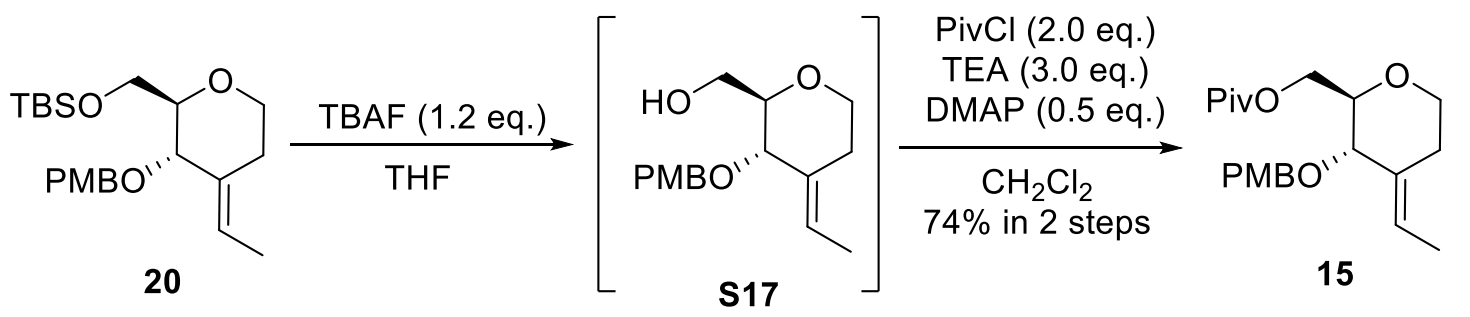

\section{Compound 15}

(Step 1): To a solution of $\mathbf{2 0}$ (2.45 g, $6.24 \mathrm{mmol}, 1.0$ equiv.) in dry THF (35 ml) was added TBAF (1M THF solution) (7.5 ml, $7.50 \mathrm{mmol}, 1.2$ equiv.) at room temperature. After stirring for $12 \mathrm{~h}$, the reaction mixture was quenched with saturated $\mathrm{NH}_{4} \mathrm{Cl}$ aq. The organic compounds were extracted with EtOAc. The organic layers were combined, and the solution was dried over anhydrous $\mathrm{Na}_{2} \mathrm{SO}_{4}$, and concentrated under reduced pressure. The residue was passed through a short silica gel column $(n$-hexane/EtOAc $=1 / 1)$ to give the crude $\mathrm{S} 17(1.40 \mathrm{~g}, 5.03 \mathrm{mmol})$.

(Step 2): To a solution of $\mathrm{S} 17$ (1.40 g, $5.03 \mathrm{mmol}, 1.0$ equiv.) in dry $\mathrm{CH}_{2} \mathrm{Cl}_{2}(20 \mathrm{ml})$ were added $\mathrm{PivCl}(1.24 \mathrm{~g}, 10.3$ mmol, 2.0 equiv.), TEA (1.53 g, $15.1 \mathrm{mmol}, 3.0$ equiv.) and DMAP (309 mg, $2.53 \mathrm{mmol}, 0.5$ equiv.) at room temperature. After stirring for $3 \mathrm{~h}$, the reaction mixture was quenched with saturated $\mathrm{NH}_{4} \mathrm{Cl}$ aq. The organic compounds were extracted with $\mathrm{CH}_{2} \mathrm{Cl}_{2}$. The organic layers were combined, and the solution was dried over anhydrous $\mathrm{Na}_{2} \mathrm{SO}_{4}$, and concentrated under reduced pressure. The residue was purified by silica gel column chromatography $(n$-hexane/EtOAc $=10 / 1)$ to give $\mathbf{1 6}(1.68 \mathrm{~g}, 4.63 \mathrm{mmol}, 74 \%$ in 2 steps $)$ as a colorless oil.

${ }^{1} \mathrm{H}-\mathrm{NMR}\left(\mathrm{CDCl}_{3}, 400 \mathrm{MHz}\right) \delta: 7.26(2 \mathrm{H}, \mathrm{d}, J=8.7 \mathrm{~Hz}), 6.88(2 \mathrm{H}, \mathrm{d}, J=8.7 \mathrm{~Hz}), 5.61(1 \mathrm{H}, \mathrm{q}, J=6.9 \mathrm{~Hz}), 4.57(1 \mathrm{H}$, d, $J=11.0 \mathrm{~Hz}), 4.33(1 \mathrm{H}, \mathrm{d}, J=11.0 \mathrm{~Hz}), 4.30-4.20(2 \mathrm{H}, \mathrm{m}), 3.91(1 \mathrm{H}, \mathrm{m}), 3.80(3 \mathrm{H}, \mathrm{s}), 3.69(1 \mathrm{H}, \mathrm{m}), 3.50(1 \mathrm{H}, \mathrm{m})$, $3.44(1 \mathrm{H}, \mathrm{dt}, J=10.5,3.2 \mathrm{~Hz}), 2.57(1 \mathrm{H}, \mathrm{m}), 2.12(1 \mathrm{H}, \mathrm{m}), 1.67(3 \mathrm{H}, \mathrm{d}, J=6.9 \mathrm{~Hz}), 1.19(9 \mathrm{H}, \mathrm{s}) .{ }^{13} \mathbf{C}-\mathbf{N M R}\left(\mathrm{CDCl}_{3}\right.$, $100 \mathrm{MHz}) \delta$; 12.5, 27.2, 27.8, 38.8, 55.2, 63.3, 66.8, 71.7, 77.6, 79.3, 113.8, 117.1, 129.5, 130.0, 133.4, 159.2, 178.2. HRMS (MALDI-TOF) $\mathrm{m} / z 385.1980\left(\right.$ calcd for $\left.\mathrm{C}_{21} \mathrm{H}_{30} \mathrm{O}_{5} \mathrm{Na}[\mathrm{M}+\mathrm{Na}]^{+}, 385.1986\right)$. $[\alpha]^{23}{ }_{\mathrm{D}}=+86.6\left(\mathrm{c} 0.20, \mathrm{CHCl}_{3}\right.$ ).

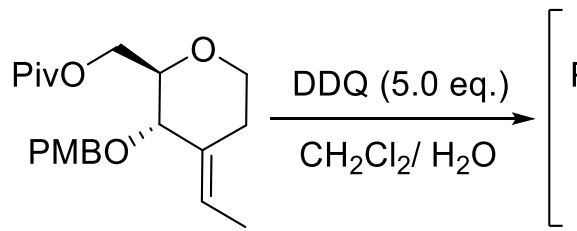

15

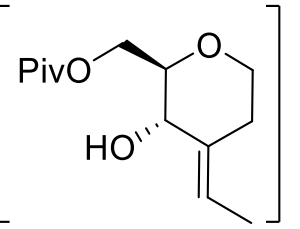

S18

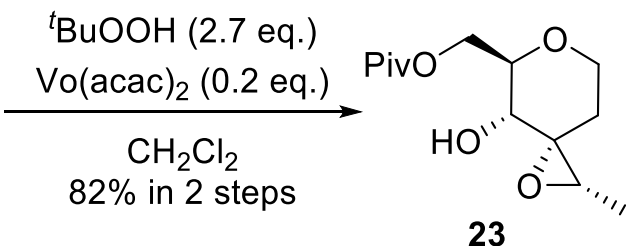

23

\section{Compound 23}

(Step 1): To a solution of $\mathbf{1 5}$ (2.40 g, $6.62 \mathrm{mmol}, 1.0$ equiv.) in $\mathrm{CH}_{2} \mathrm{Cl}_{2} / \mathrm{H}_{2} \mathrm{O}(10: 1,150 \mathrm{ml})$ was added DDQ (7.51 $\mathrm{g}, 33.1 \mathrm{mmol}, 5.0$ equiv.) at room temperature. After stirring for $12 \mathrm{~h}$, the reaction mixture was quenched with saturated $\mathrm{NaHCO}_{3}$ aq and saturated $\mathrm{Na}_{2} \mathrm{~S}_{2} \mathrm{O}_{3}$ aq. The organic compounds were extracted with $\mathrm{CH}_{2} \mathrm{Cl}_{2}$. The organic layers were combined, and the solution was dried over anhydrous $\mathrm{Na}_{2} \mathrm{SO}_{4}$, and concentrated under reduced pressure. The residue was passed through a short silica gel column $(n$-hexane/EtOAc $=3 / 1)$ to give the crude S18. 
(Step 2): To a solution of $\mathrm{S18}$ in dry $\mathrm{CH}_{2} \mathrm{Cl}_{2}(60 \mathrm{ml})$ were added ${ }^{t} \mathrm{BuOOH}$ (5.5M in decane solution) (3.2 ml, 17.6 mmol, 2.7 equiv.) and $\mathrm{Vo}(\mathrm{acac})_{2}(311 \mathrm{mg}, 1.17 \mathrm{mmol}, 0.2$ equiv.) at room temperature. After stirring for $1 \mathrm{~h}$, the reaction mixture was quenched with saturated $\mathrm{NaHCO}_{3}$ aq and saturated $\mathrm{Na}_{2} \mathrm{~S}_{2} \mathrm{O}_{3}$ aq. The organic compounds were extracted with $\mathrm{CH}_{2} \mathrm{Cl}_{2}$. The organic layers were combined, and the solution was dried over anhydrous $\mathrm{Na}_{2} \mathrm{SO}_{4}$, and concentrated under reduced pressure. The residue was purified by silica gel column chromatography $(n$ hexane/EtOAc $=2 / 1)$ to give $\mathbf{2 3}(1.41 \mathrm{~g}, 5.46 \mathrm{mmol}, 82 \%$ in 2 steps $)$ as a colorless oil.

${ }^{1}$ H-NMR $\left(\mathrm{CDCl}_{3}, 300 \mathrm{MHz}\right) \delta: 4.40(1 \mathrm{H}, \mathrm{dd}, J=11.9,2.3 \mathrm{~Hz}), 4.30(1 \mathrm{H}, \mathrm{dd}, J=11.9,5.0 \mathrm{~Hz}), 4.02(1 \mathrm{H}, \mathrm{ddd}, J=$ $10.1,5.5,1.4 \mathrm{~Hz}), 3.69-3.57(2 \mathrm{H}, \mathrm{m}), 3.43(1 \mathrm{H}, \mathrm{q}, J=6.0 \mathrm{~Hz}), 3.42-3.30(2 \mathrm{H}, \mathrm{m}), 2.09(1 \mathrm{H}, \mathrm{m}), 1.98(1 \mathrm{H}, \mathrm{d}, J=10.6$ $\mathrm{Hz}), 1.55(3 \mathrm{H}, \mathrm{m}), 1.23(9 \mathrm{H}, \mathrm{s}) .{ }^{13} \mathrm{C}-\mathrm{NMR}\left(\mathrm{CDCl}_{3}, 100 \mathrm{MHz}\right) \delta$; 12.6, 27.1, 28.6, 38.9, 54.4, 61.7, 64.1, 65.1, 65.3, 78.6, 178.7. HRMS (MALDI-TOF) $\mathrm{m} / z 281.1359$ (calcd for $\mathrm{C}_{13} \mathrm{H}_{22} \mathrm{O}_{5} \mathrm{Na}[\mathrm{M}+\mathrm{Na}]^{+}, 281.1359$ ). $[\alpha]^{23}{ }_{\mathrm{D}}=+10.9$ (c $\left.0.10, \mathrm{CHCl}_{3}\right)$.

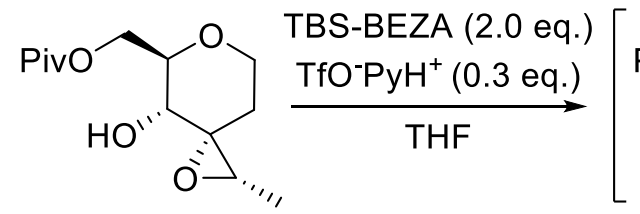

23

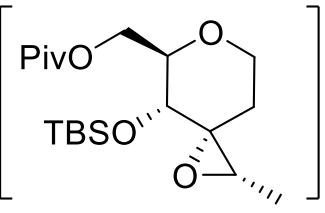

S19

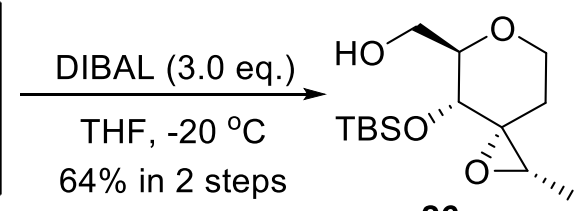

26

\section{Compound 26}

(Step 1): To a solution of $\mathbf{2 6}(810 \mathrm{mg}, 3.14 \mathrm{mmol}, 1.0$ equiv.) in dry THF ( $8.0 \mathrm{ml})$ was added TBS-BEZA (1955 mg, $6.28 \mathrm{mmol}, 2.0$ equiv.) and $\mathrm{TfO}^{-} \mathrm{PyH}^{+}(185 \mathrm{mg}, 0.807 \mathrm{mmol}, 0.3$ equiv.) at room temperature. After stirring for $12 \mathrm{~h}$, the reaction mixture was quenched with saturated $\mathrm{NaHCO}_{3}$ aq. The organic compounds were extracted with EtOAc. The organic layers were combined, and the solution was dried over anhydrous $\mathrm{Na}_{2} \mathrm{SO}_{4}$, and concentrated under reduced pressure. The residue was passed through a short silica gel column $(n$-hexane/EtOAc $=7 / 1)$ to give the crude S19 (910 mg, $2.44 \mathrm{mmol}$ ).

(Step 2): To a solution of $\mathbf{S 1 9}$ (910 mg, $2.44 \mathrm{mmol}, 1.0$ equiv.) in dry THF (24 ml) was added DIBAL (1M toluene solution) (7.3 ml, $7.30 \mathrm{mmol}, 3.0$ equiv.) at $-20^{\circ} \mathrm{C}$. After stirring for $1 \mathrm{~h}$, the reaction mixture was quenched with saturated potassium sodium tartrate aq. The organic compounds were extracted with EtOAc. The organic layers were combined, and the solution was dried over anhydrous $\mathrm{Na}_{2} \mathrm{SO}_{4}$, and concentrated under reduced pressure. The residue was purified by silica gel column chromatography $(n$-hexane/EtOAc $=2 / 1)$ to give $\mathbf{2 6}(577 \mathrm{mg}, 2.00 \mathrm{mmol}, 64 \%$ in 2 steps) as a colorless oil.

${ }^{1} \mathrm{H}-\mathrm{NMR}\left(\mathrm{CDCl}_{3}, 300 \mathrm{MHz}\right) \delta: 4.00(1 \mathrm{H}, \mathrm{ddd}, J=11.0,5.5,1.8 \mathrm{~Hz}), 3.79(1 \mathrm{H}, \mathrm{m}), 3.75(1 \mathrm{H}, \mathrm{d}, J=4.1 \mathrm{~Hz}), 3.72$ $(1 \mathrm{H}, \mathrm{m}), 3.63(1 \mathrm{H}, \mathrm{m}), 3.53(1 \mathrm{H}, \mathrm{ddd}, J=8.7,50 ., 2.7 \mathrm{~Hz}), 3.34(1 \mathrm{H}, \mathrm{q}, J=5.5 \mathrm{~Hz}), 1.97(1 \mathrm{H}, \mathrm{m}), 1.94(1 \mathrm{H}, \mathrm{t}, J=$ $6.4 \mathrm{~Hz}), 1.50(1 \mathrm{H}, \mathrm{m}), 1.27(3 \mathrm{H}, \mathrm{d}, J=5.5 \mathrm{~Hz}), 0.90(9 \mathrm{H}, \mathrm{s}), 0.11(3 \mathrm{H}, \mathrm{s}), 0.05(3 \mathrm{H}, \mathrm{s}) .{ }^{13} \mathbf{C}-\mathbf{N M R}\left(\mathrm{CDCl}_{3}, 100 \mathrm{MHz}\right)$ $\delta$; -4.8, -4.7, 12.8, 18.0, 25.7, 29.6, 54.6, 62.1, 62.8, 65.0, 67.2, 79.5. HRMS (MALDI-TOF) $\mathrm{m} / z$ 311.1645 (calcd for $\left.\mathrm{C}_{14} \mathrm{H}_{28} \mathrm{O}_{4} \mathrm{SiNa}[\mathrm{M}+\mathrm{Na}]^{+}, 311.1649\right) .[\alpha]^{23} \mathrm{D}=+59.0\left(\mathrm{c} \mathrm{0.19}, \mathrm{CHCl}_{3}\right)$. 


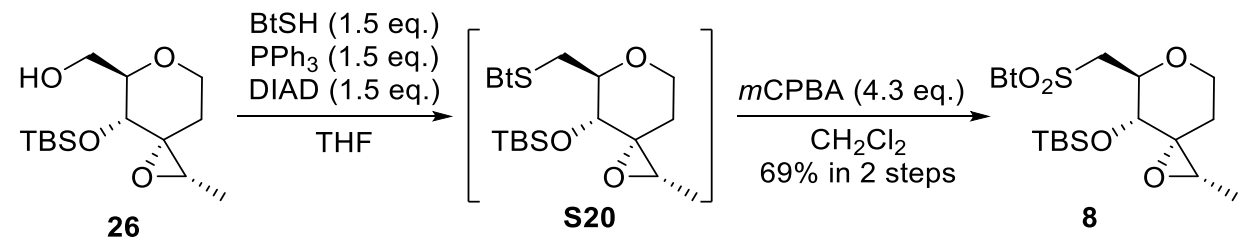

\section{Compound 8}

(Step 1): To a solution of $\mathbf{2 6}$ (150 mg, $0.520 \mathrm{mmol}, 1.0$ equiv.) in dry THF (3.5 ml) was added BtSH (131 mg, 0.783 mmol, 1.5 equiv.), $\mathrm{PPh}_{3}$ (205 mg, $0.782 \mathrm{mmol}, 1.5$ equiv.) and DIAD (0.15 ml, $0.78 \mathrm{mmol}, 1.5$ equiv.) at room temperature. After stirring for $2 \mathrm{~h}$, the reaction mixture was quenched with $\mathrm{H}_{2} \mathrm{O}$. The organic compounds were extracted with EtOAc. The organic layers were combined, and the solution was dried over anhydrous $\mathrm{Na}_{2} \mathrm{SO}_{4}$, and concentrated under reduced pressure. The residue was passed through a short silica gel column $(n$-hexane/EtOAc $=$ 7/1) to give the crude $\mathbf{S 2 0}$.

(Step 2): To a solution of above $\mathbf{S 2 0}$ in dry $\mathrm{CH}_{2} \mathrm{Cl}_{2}(2.0 \mathrm{ml})$ was added $m$-CPBA (382 $\mathrm{mg}, 2.21 \mathrm{mmol}, 4.3$ equiv.) at room temperature. After stirring for $2 \mathrm{~h}$, the reaction mixture was quenched with saturated $\mathrm{NaHCO}_{3}$ aq and saturated $\mathrm{Na}_{2} \mathrm{~S}_{2} \mathrm{O}_{3}$ aq. The organic compounds were extracted with $\mathrm{CH}_{2} \mathrm{Cl}_{2}$. The organic layers were combined, and the solution was dried over anhydrous $\mathrm{Na}_{2} \mathrm{SO}_{4}$, and concentrated under reduced pressure. The residue was purified by silica gel column chromatography ( $n$-hexane/EtOAc $=3 / 1)$ to give $8(170 \mathrm{mg}, 0.361 \mathrm{mmol}, 69 \%$ in 2 steps) as a white solid (mp $145-148^{\circ} \mathrm{C}$ ).

${ }^{1} \mathrm{H}-\mathrm{NMR}\left(\mathrm{CDCl}_{3}, 400 \mathrm{MHz}\right) \delta: 8.20(1 \mathrm{H}, \mathrm{d}, J=8.1 \mathrm{~Hz}), 8.00(1 \mathrm{H}, \mathrm{d}, J=8.1 \mathrm{~Hz}), 7.64-7.55(2 \mathrm{H}, \mathrm{m}), 4.15(1 \mathrm{H}, \mathrm{m})$, $3.82(1 \mathrm{H}, \mathrm{dd}, J=14.7,2.3 \mathrm{~Hz}), 3.72(1 \mathrm{H}, \mathrm{dd}, J=14.7,10.1 \mathrm{~Hz}), 3.61-3.56(2 \mathrm{H}, \mathrm{m}), 3.56(1 \mathrm{H}, \mathrm{d}, J=8.7 \mathrm{~Hz}), 3.26$ $(1 \mathrm{H}, \mathrm{q}, J=5.8 \mathrm{~Hz}), 1.84(1 \mathrm{H}, \mathrm{m}), 1.44(1 \mathrm{H}, \mathrm{m}), 1.23(3 \mathrm{H}, \mathrm{d}, J=5.8 \mathrm{~Hz}), 0.90(9 \mathrm{H}, \mathrm{s}), 0.11(3 \mathrm{H}, \mathrm{s}), 0.04(3 \mathrm{H}, \mathrm{s}) .{ }^{13} \mathrm{C}-$ NMR $\left(\mathrm{CDCl}_{3}, 100 \mathrm{MHz}\right) \delta ;-4.5,-4.2,12.7,18.0,25.6,29.0,54.9,57.0,62.1,64.9,69.9,74.8,122.2,125.4,127.4$, 127.8, 136.9, 152.5, 167.0. HRMS (MALDI-TOF) $m / z 492.1311$ (calcd for $\mathrm{C}_{21} \mathrm{H}_{31} \mathrm{NO}_{5} \mathrm{NaSiS}_{2}[\mathrm{M}+\mathrm{Na}]^{+}, 492.1305$ ). $[\alpha]^{23} \mathrm{D}=+5.95\left(\mathrm{c} 0.20, \mathrm{CHCl}_{3}\right)$.
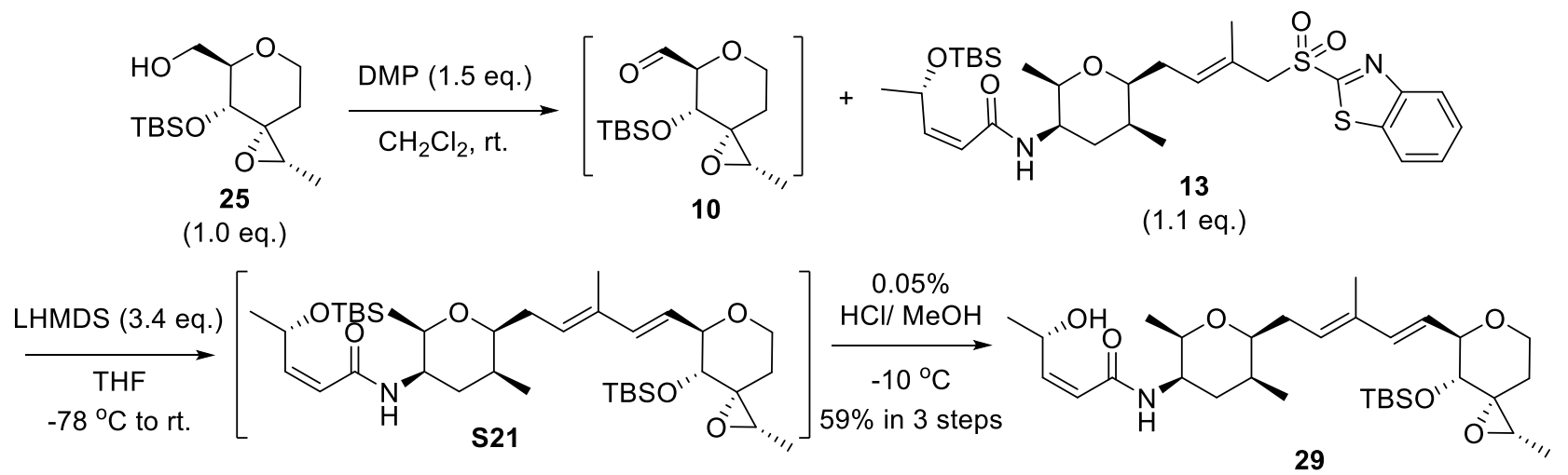

\section{Compound 29}

(Step 1): To a solution of $\mathbf{2 5}\left(33.5 \mathrm{mg}, 0.116 \mathrm{mmol}, 1.0\right.$ equiv.) in dry $\mathrm{CH}_{2} \mathrm{Cl}_{2}(1.1 \mathrm{ml})$ was added DMP (76.0 mg, 
0.179 mmol, 1.5 equiv.) at room temperature. After stirring for $2 \mathrm{~h}$, the reaction mixture was diluted with $\mathrm{Et}_{2} \mathrm{O}$ and quenched with saturated $\mathrm{NaHCO}_{3}$ aq and saturated $\mathrm{Na}_{2} \mathrm{~S}_{2} \mathrm{O}_{3}$ aq. The organic compounds were extracted with $\mathrm{Et}_{2} \mathrm{O}$. The organic layers were combined, and the solution was dried over anhydrous $\mathrm{Na}_{2} \mathrm{SO}_{4}$, and concentrated under reduced pressure to give the crude $\mathbf{1 0 .}$

(Step 2): To a solution of $\mathbf{1 3}$ (75.1 $\mathrm{mg}, 0.124 \mathrm{mmol}, 1.1$ equiv.) and $\mathbf{1 0}$ in dry THF (1.2 ml) was added LHMDS (1M THF solution) ( $0.4 \mathrm{ml}, 0.400 \mathrm{mmol}, 3.4$ equiv.) at $-78^{\circ} \mathrm{C}$. After $30 \mathrm{~min}$, the solution was warm to room temperature and stirred for $23 \mathrm{~h}$. The reaction mixture was quenched with saturated $\mathrm{NH}_{4} \mathrm{Cl}$ aq. The organic compounds were extracted with EtOAc. The organic layers were combined, and the solution was dried over anhydrous $\mathrm{Na}_{2} \mathrm{SO}_{4}$, and concentrated under reduced pressure. The residue was passed through a short silica gel column $(n$-hexane/EtOAc $=$ 3/1) to give the crude S21.

(Step 3): To S21 was added $0.05 \% \mathrm{HCl} / \mathrm{MeOH}(3.0 \mathrm{ml})$ at $-10{ }^{\circ} \mathrm{C}$. After stirring for $12 \mathrm{~h}$, the reaction mixture was quenched with saturated $\mathrm{NaHCO}_{3}$ aq. The organic compounds were extracted with EtOAc. The organic layers were combined, and the solution was dried over anhydrous $\mathrm{Na}_{2} \mathrm{SO}_{4}$, and concentrated under reduced pressure. The residue was purified by silica gel column chromatography $(n$-hexane/EtOAc $=1 / 1)$ to give $\mathbf{2 9}(38.2 \mathrm{mg}, 0.068 \mathrm{mmol}, 59 \%$ in 3 steps) as a colorless amorphous solid.

${ }^{1} \mathrm{H}-\mathrm{NMR}\left(\mathrm{CDCl}_{3}, 500 \mathrm{MHz}\right) \delta: 6.29(1 \mathrm{H}, \mathrm{d}, J=15.8 \mathrm{~Hz}), 6.17(1 \mathrm{H}, \mathrm{dd}, J=12.1,5.2 \mathrm{~Hz}), 5.93(1 \mathrm{H}, \mathrm{d}, J=9.2 \mathrm{~Hz})$, $5.70(1 \mathrm{H}, \mathrm{dd}, J=12.1,1.7 \mathrm{~Hz}), 5.58(1 \mathrm{H}, \mathrm{d}, J=4.6 \mathrm{~Hz}), 5.52(1 \mathrm{H}, \mathrm{dd}, J=15.8,6.9 \mathrm{~Hz}), 5.44(1 \mathrm{H}, \mathrm{t}, J=7.2 \mathrm{~Hz})$, $4.77(1 \mathrm{H}, \mathrm{m}), 4.02-3.90(3 \mathrm{H}, \mathrm{m}), 3.75(1 \mathrm{H}, \mathrm{dt}, J=12.1,2.3 \mathrm{~Hz}), 3.65(1 \mathrm{H}, \mathrm{m}), 3.55(1 \mathrm{H}, \mathrm{d}, J=8.6 \mathrm{~Hz}), 3.52(1 \mathrm{H}$, m), $3.33(1 \mathrm{H}, \mathrm{q}, J=5.6 \mathrm{~Hz}), 2.37(1 \mathrm{H}, \mathrm{m}), 2.24(1 \mathrm{H}, \mathrm{m}), 1.99(1 \mathrm{H}, \mathrm{m}), 1.93(2 \mathrm{H}, \mathrm{m}), 1.76(1 \mathrm{H}, \mathrm{m}), 1.74(3 \mathrm{H}, \mathrm{s}), 1.52$ $(1 \mathrm{H}, \mathrm{m}), 1.34(3 \mathrm{H}, \mathrm{d}, J=6.3 \mathrm{~Hz}), 1.26(3 \mathrm{H}, \mathrm{d}, J=5.6 \mathrm{~Hz}), 1.12(3 \mathrm{H}, \mathrm{d}, J=6.3 \mathrm{~Hz}), 0.98(3 \mathrm{H}, \mathrm{d}, J=7.5 \mathrm{~Hz}), 0.84$ $(9 \mathrm{H}, \mathrm{s}), 0.003(3 \mathrm{H}, \mathrm{s}),-0.041$ (3H, s). ${ }^{13} \mathbf{C}-\mathbf{N M R}\left(\mathrm{CDCl}_{3}, 125 \mathrm{MHz}\right) \delta ;-4.5,-4.2,12.5,12.9,15.1,17.8,18.0,22.7$, 25.7, 28.8, 29.7, 31.9, 35.7, 47.5, 54.9, 62.9, 64.6, 64.9, 71.3, 75.8, 80.9, 81.0, 122.5, 124.5, 128.5, 134.5, 138.0, 150.7, 166.1.HRMS (MALDI-TOF) $\mathrm{m} / z 586.3535$ (calcd for $\mathrm{C}_{31} \mathrm{H}_{53} \mathrm{NO}_{6} \mathrm{SiNa}[\mathrm{M}+\mathrm{Na}]^{+}, 586.3534$ ). $[\alpha]^{23}{ }_{\mathrm{D}}=+5.94$ (c $0.09, \mathrm{CHCl}_{3}$ ).

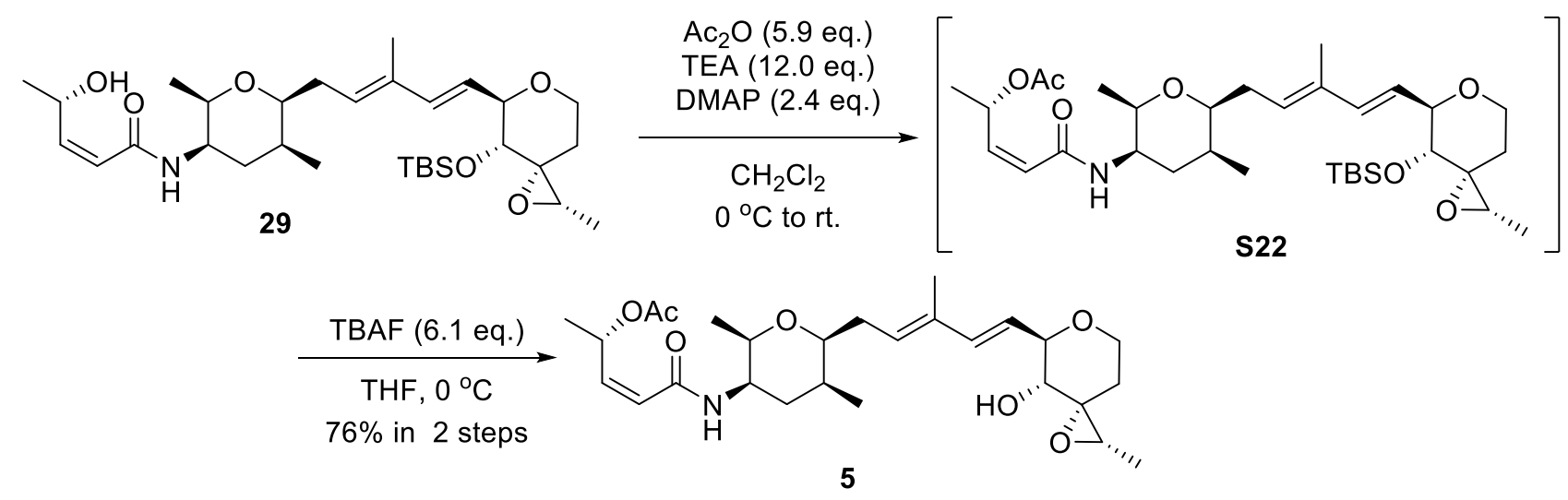

\section{Compound 5}


(Step 1): To a solution of 29 (38.2 mg, $0.068 \mathrm{mmol}, 1.0$ equiv.) in dry $\mathrm{CH}_{2} \mathrm{Cl}_{2}$ (2.0 ml) was added TEA ( $82.3 \mathrm{mg}$, $0.813 \mathrm{mmol}, 12.0$ equiv.), DMAP (20.2 mg, $0.165 \mathrm{mmol}, 2.4$ equiv.) then $\mathrm{Ac}_{2} \mathrm{O}$ (38 $\mu 1,0.402 \mathrm{mmol}, 5.9$ equiv.) at $0{ }^{\circ} \mathrm{C}$ and the gradually warm to room temperature. After stirring for $1 \mathrm{~h}$, the reaction mixture was quenched with saturated $\mathrm{NH}_{4} \mathrm{Cl}$ aq. The organic compounds were extracted with $\mathrm{CH}_{2} \mathrm{Cl}_{2}$. The organic layers were combined, and the solution was dried over anhydrous $\mathrm{Na}_{2} \mathrm{SO}_{4}$, and concentrated under reduced pressure. The residue was passed through a short silica gel column $(n$-hexane/EtOAc $=3 / 1)$ to give the crude $\mathbf{S 2 2}(34.5 \mathrm{mg}, 0.057 \mathrm{mmol})$.

(Step 2): To a solution of crude $\mathbf{S 2 2}$ (34.5 mg, $0.057 \mathrm{mmol}, 1.0$ equiv.) in dry THF (3.0 ml) was added TBAF (1M THF solution) ( $0.35 \mathrm{ml}, 0.350 \mathrm{mmol}, 6.1$ equiv.) at $0{ }^{\circ} \mathrm{C}$. After stirring for $12 \mathrm{~h}$, the reaction mixture was quenched with saturated $\mathrm{NH}_{4} \mathrm{Cl}$ aq. The organic compounds were extracted with EtOAc. The organic layers were combined, and the solution was dried over anhydrous $\mathrm{Na}_{2} \mathrm{SO}_{4}$, and concentrated under reduced pressure. The residue was purified by silica gel column chromatography $(n$-hexane/EtOAc $=1 / 2)$ to give $5(25.8 \mathrm{mg}, 0.052 \mathrm{mmol}, 76 \%$ in 2 steps) as a white solid (mp $\left.92-95^{\circ} \mathrm{C}\right)$.

${ }^{1} \mathrm{H}-\mathrm{NMR}\left(\mathrm{CDCl}_{3}, 500 \mathrm{MHz}\right) \delta: 6.38(1 \mathrm{H}, \mathrm{d}, J=15.5 \mathrm{~Hz}), 6.25(1 \mathrm{H}, \mathrm{m}), 6.01(1 \mathrm{H}, \mathrm{d}, J=9.2 \mathrm{~Hz}), 5.88(1 \mathrm{H}, \mathrm{dd}, J=$ 10.1, $6.7 \mathrm{~Hz}), 5.71(1 \mathrm{H}, \mathrm{m}), 5.68(1 \mathrm{H}, \mathrm{m}), 5.49(1 \mathrm{H}, \mathrm{t}, J=6.9 \mathrm{~Hz}), 4.04(1 \mathrm{H}, \mathrm{d}, J=11.5,4.6 \mathrm{~Hz}), 3.92(1 \mathrm{H}, \mathrm{m}), 373-$ $3.68(2 \mathrm{H}, \mathrm{m}), 3.65(1 \mathrm{H}, \mathrm{m}), 3.54-3.49(2 \mathrm{H}, \mathrm{m}), 3.43(1 \mathrm{H}, \mathrm{q}, J=5.7 \mathrm{~Hz}), 2.38(1 \mathrm{H}, \mathrm{m}), 2.22(1 \mathrm{H}, \mathrm{m}), 2.12(1 \mathrm{H}, \mathrm{m})$, $2.03(3 \mathrm{H}, \mathrm{s}), 1.98-1.89(2 \mathrm{H}, \mathrm{m}), 1.79(1 \mathrm{H}, \mathrm{m}), 1.77(3 \mathrm{H}, \mathrm{s}), 1.71(1 \mathrm{H}, \mathrm{d}, J=10.3 \mathrm{~Hz}), 1.57(1 \mathrm{H}, \mathrm{m}), 1.38(3 \mathrm{H}, \mathrm{d}, J=$ $6.9 \mathrm{~Hz}), 1.30(3 \mathrm{H}, \mathrm{d}, J=5.7 \mathrm{~Hz}), 1.13(3 \mathrm{H}, \mathrm{d}, J=6.3 \mathrm{~Hz}), 1.00(3 \mathrm{H}, \mathrm{d}, J=7.5 \mathrm{~Hz}) .{ }^{13} \mathbf{C}-\mathbf{N M R}\left(\mathrm{CDCl}_{3}, 125 \mathrm{MHz}\right) \delta$; 12.6, 12.7, 15.0, 17.8, 20.0, 21.2, 28.8, 28.9, 31.9, 35.8, 47.1, 54.4, 61.9, 64.9, 68.9, 69.2, 75.9, 80.8, 80.9, 122.5, 124.3, 129.0, 134.6, 137.9, 143.6, 164.8, 170.3. HRMS (MALDI-TOF) $m / z 514.2772$ (calcd for $\mathrm{C}_{27} \mathrm{H}_{41} \mathrm{NO}_{7} \mathrm{Na}$ $\left.[\mathrm{M}+\mathrm{Na}]^{+}, 514.2775\right) \cdot[\alpha]^{23} \mathrm{D}=-37.9\left(\mathrm{c} 0.02, \mathrm{CHCl}_{3}\right)$.

\section{Analytical RP-HPLC}

HPLC purity determination of compound 3, 4 and $\mathbf{5}$ was performed on a reversed CEL (Mightysil RP-18 GP 250$10)$.

\section{Compound 3}

Purity is $>95 \%$. Condition : eluting with acetonitrile and water $(70: 30,0.2 \mathrm{ml} / \mathrm{min})$ over $30 \mathrm{~min}$. UV detection $(\lambda$ $=254 \mathrm{~nm})$ 


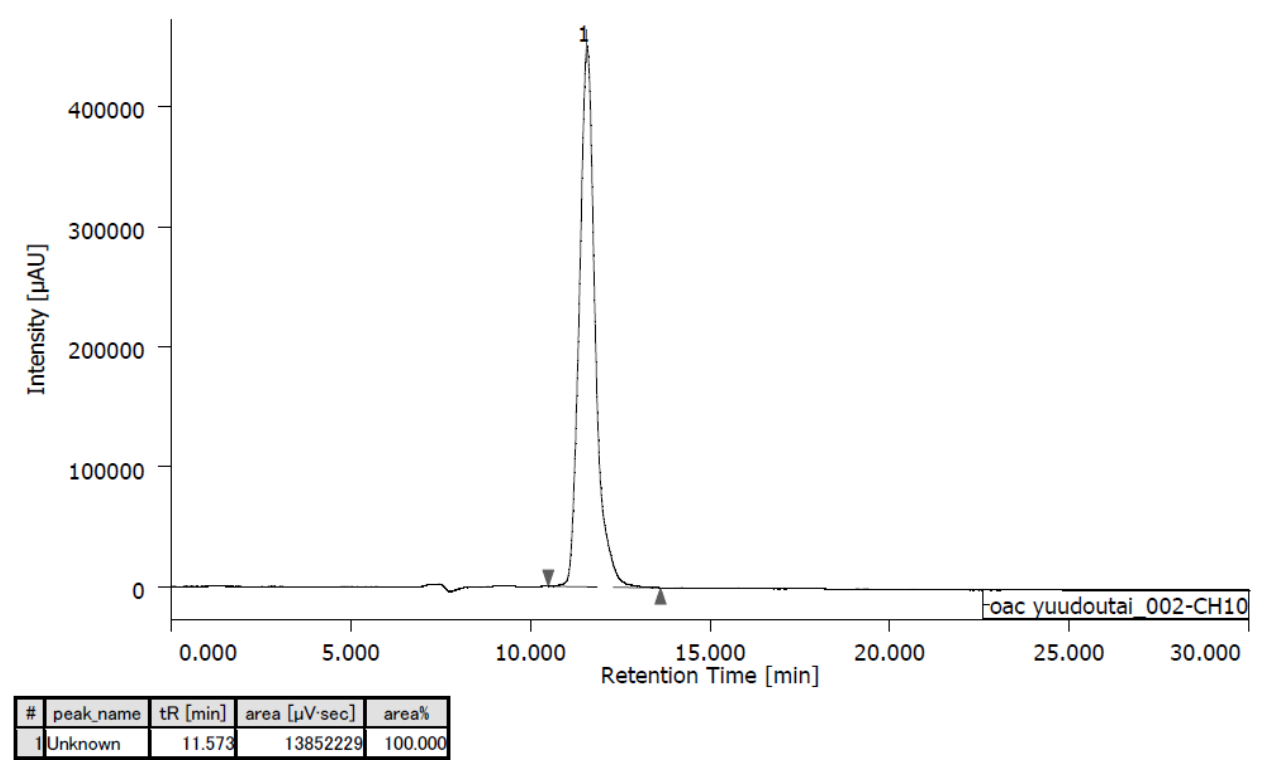

\section{Compound 4}

Purity is $>95 \%$. Condition : eluting with acetonitrile and water $(60: 40,0.4 \mathrm{ml} / \mathrm{min})$ over $30 \mathrm{~min}$. UV detection $(\lambda$ $=210 \mathrm{~nm})$

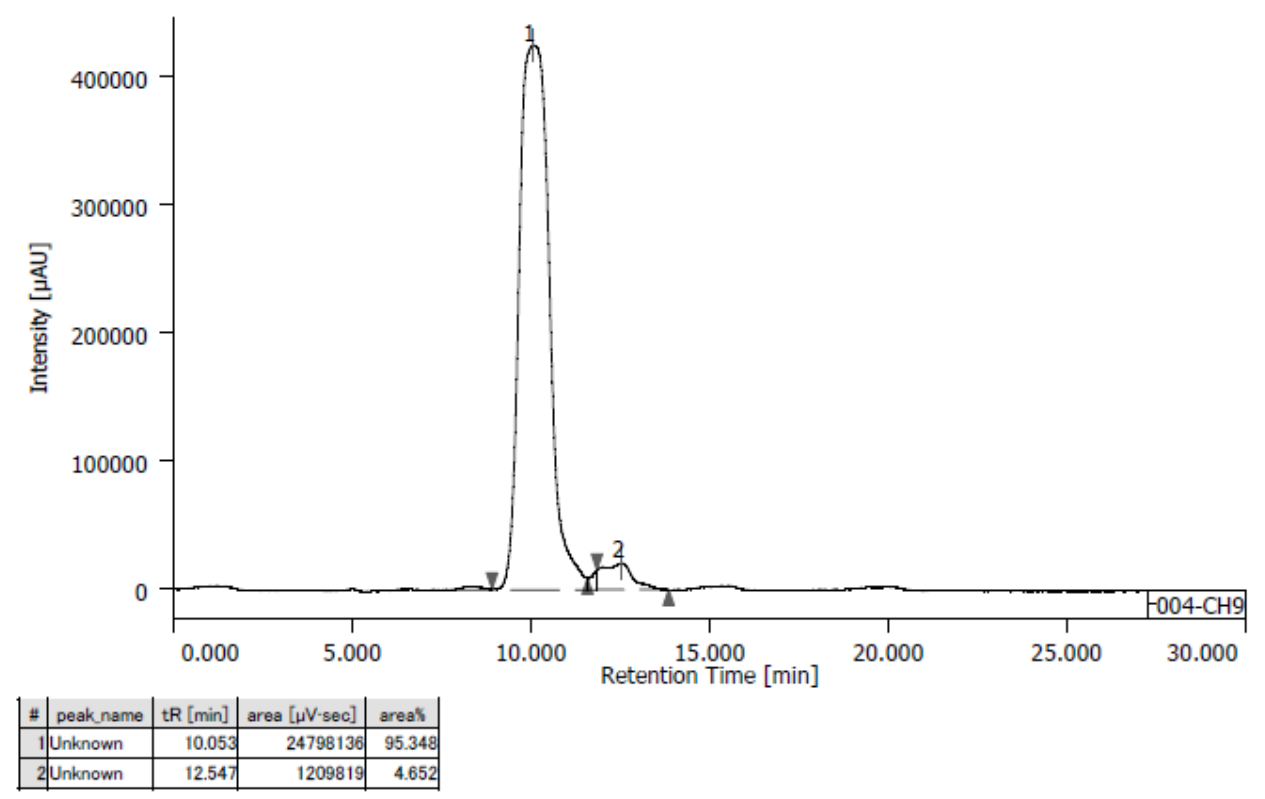

\section{Compound 5}

Purity is $>95 \%$. Condition : eluting with acetonitrile and water $(80: 20,0.3 \mathrm{ml} / \mathrm{min})$ over $20 \mathrm{~min}$. UV detection $(\lambda$ $=210 \mathrm{~nm})$ 


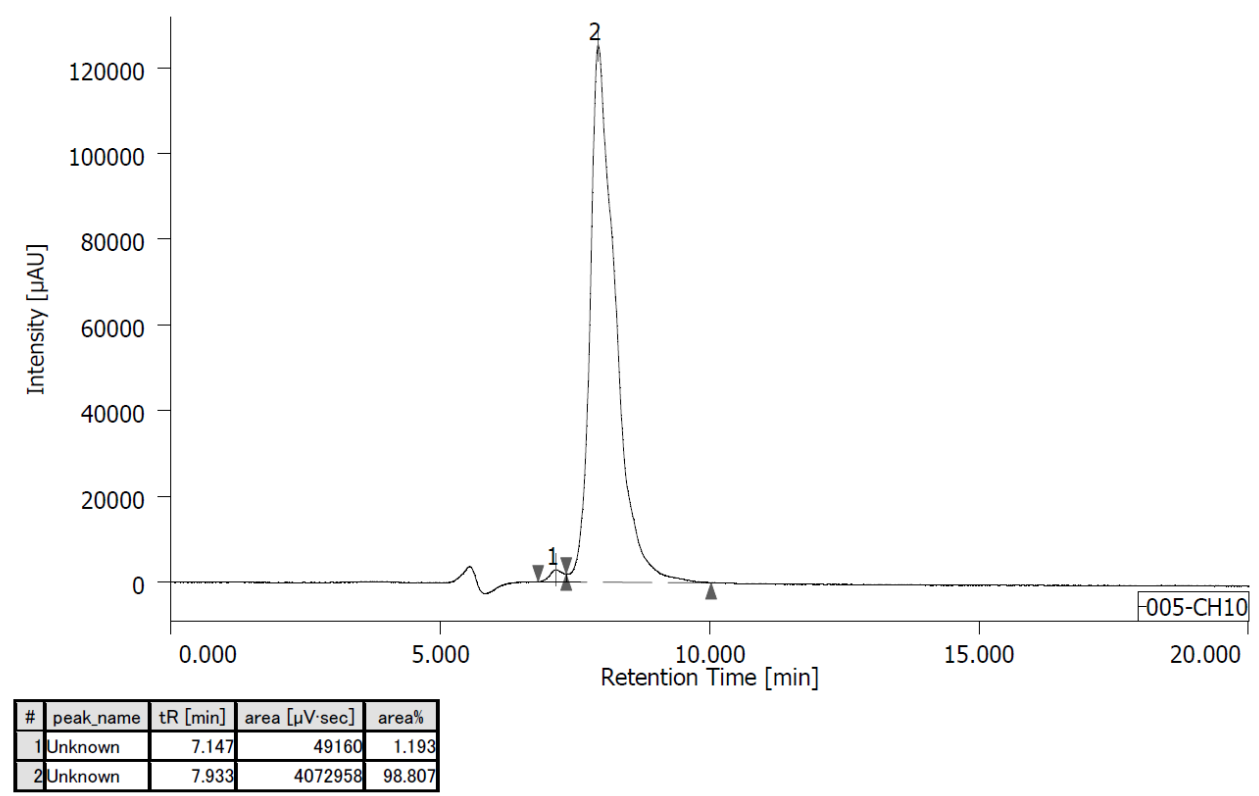

\section{Biological Assay}

Method 
AR-V7-GFP splicing assay. AR-V7-GFP CWR22Rv1 cell was previously established and cultured as previously described $^{5}$. GFP signals can be used for quantitative examination of AR-V7 splicing in this system. After three days of treatment, GFP expression was measured by FACSAria II (BD Biosciences) as previously described. IC $_{50}$ was calculated using approximate curves ${ }^{5}$.

In vivo toxicity test. Animal experiments were approved by the Osaka University Animal Experiments committee and were performed following the guidelines. Spliceostain A or its derivatives (3-5) were intraperitoneally injected into eight to ten-week-old C57BL/6 male mice with $300 \mu \mathrm{l}$ PBS containing 10\% DMSO three times on every other day. Body weight was measured on every other day.

AR-V7-GFP expression assay for $\mathbf{3 , 4 , 5}$
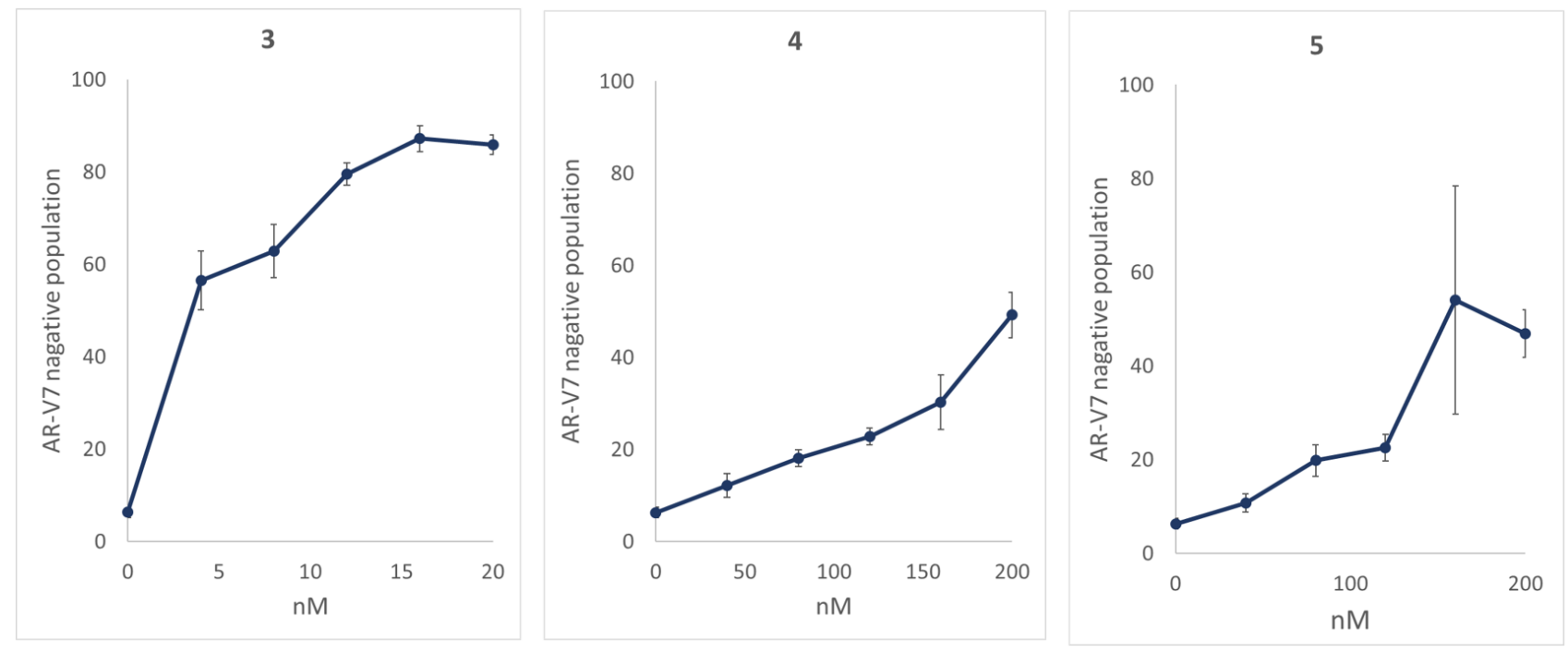

\section{Reference}

1) Catino, A. J.; Sherlock, A.; Shieh, P.; Wzorek, J. S.; Evans, D. A. Org. Lett. 2013, 15, 3330-3333.

2) Yoshikawa, Y.; Ishibashi, A.; Murai, K.; Kaneda, Y.; Nimura, K.; Arisawa, M. Tetrahedron Lett. 10.1016/j.tetlet.2019.151313.

3) Fujiwara, T.; Hayashi, M. J. Org. Chem. 2008, 73, 9161-9163.

4) Motoyoshi, H.; Horigome, M.; Watanabe, H.; Kitahara, T. Tetrahedron 2006, 62, 1378-1389

5) N. Kawamura, K. Nimura, K. Saga, A. Ishibashi, K. Kitamura, H. Nagano, Y. Yoshikawa, K. Ishida, N. Nonomura, M. Arisawa, J. Luo and Y. Kaneda, Can. Res. 2019, 79, 5204-5217.

\section{NMR Spectra}


single pulse

F:ISAA論文 $\backslash N M R \backslash$ muchikan OPMP ole fin 2 proton-1-1.als

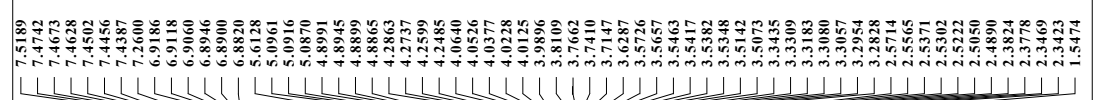

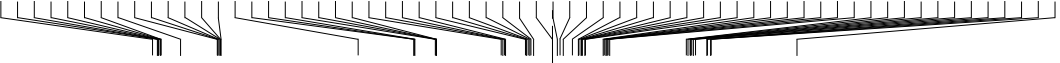

DFILE muchikan OPMP olefin2 proton-1-1.al

$\begin{array}{lll}\text { COMTIM } & \text { single pulse } \\ \text { 2019-07-24 16:54:59 }\end{array}$

OBNUC

EXMOD

OBFRQ

OBSET

$399.78 \mathrm{MHz}$
4.19
$7.29 \mathrm{KHz}$

$4.19 \mathrm{KHz}$
$7.29 \mathrm{~Hz}$

1.2107
6002.40

$\begin{array}{lr}\text { SCANS } & 5 \\ \text { ACQTM } & 2.1837 \mathrm{sec} \\ \text { PD } & 10.0000 \mathrm{sec} \\ \text { PW1 } & 7.25 \text { use }\end{array}$

IRNUC
CTEMP
SLVNT

EXREF

$1 \mathrm{H} \quad 7.25$ usec

BF

$22.6 \mathrm{c}$
$7.26 \mathrm{pp}$

$7.26 \mathrm{ppm}$
$0.12 \mathrm{~Hz}$
48<smiles>C=C1CCO[C@@H]2COC(c3ccc(OC)cc3)O[C@H]12</smiles>

17

$55 \%$ in 2 steps

single pulse decoupled gated NOE

F:ISAA論文 $\backslash N M R \backslash$ muchikan OPMP ole fin carbon-1-1.als

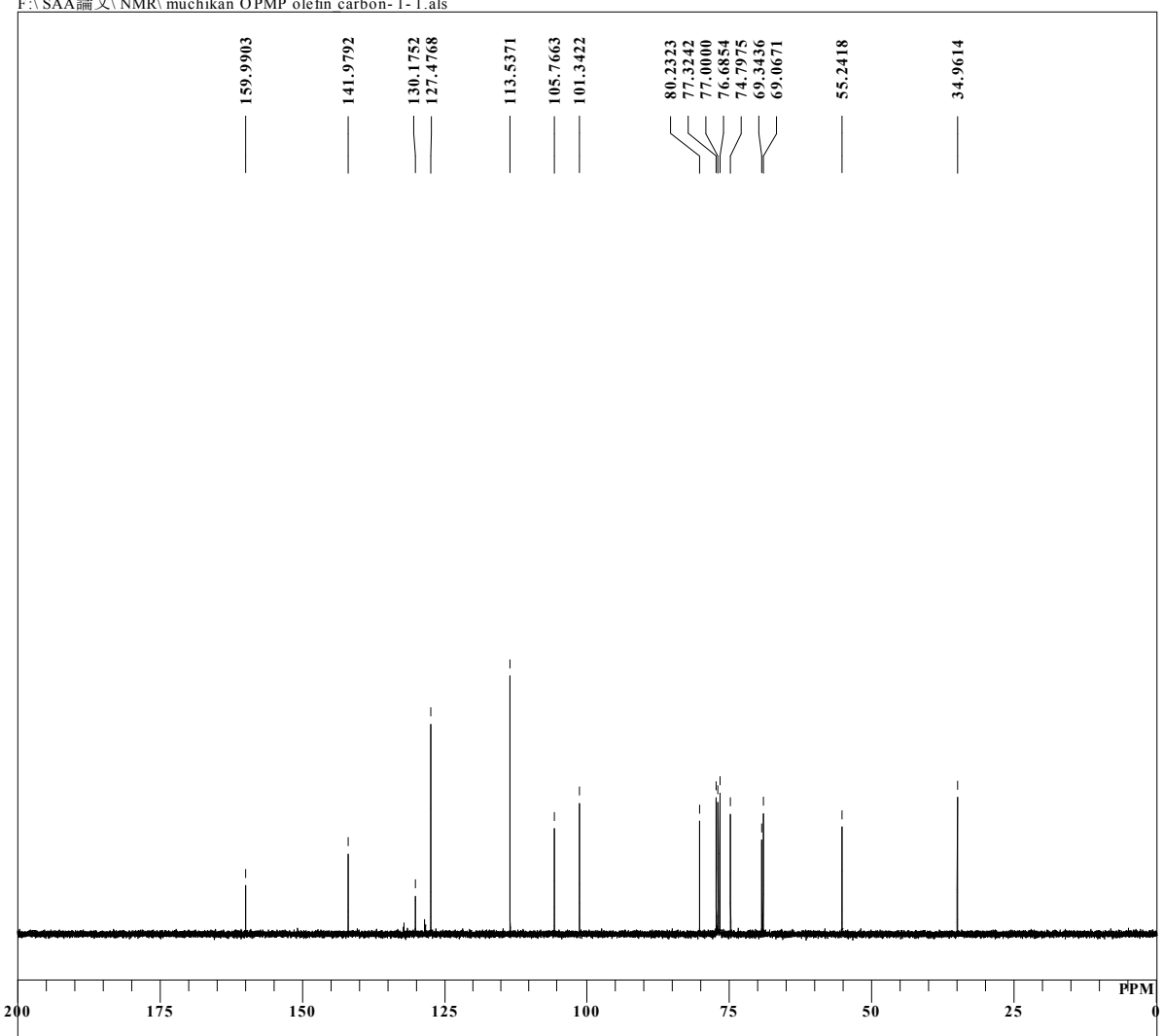

DFILE muchikan OPMP ole fin_carbon-1-1.als

EXMOD ca

\begin{tabular}{ll} 
OBFRQ & $100.53 \mathrm{MHz}$ \\
\hline
\end{tabular}

$5.35 \mathrm{KHz}$

POINT 26214

FREQU $\quad 25125.63 \mathrm{~Hz}$

$\begin{array}{lc}\text { SCANS } & 176 \\ \text { ACQTM } & 1.0433 \mathrm{sec}\end{array}$

$\begin{array}{lr}\text { PD } & 1.0000 \mathrm{sec} \\ \text { PW1 } & 3.17 \text { usec }\end{array}$

PW1

CTEMP

EXREF

$1 \mathrm{H} \quad 22.8 \mathrm{c}$

$77.00 \mathrm{ppm}$
$0.12 \mathrm{~Hz}$

RGAIN $\quad 0.12 \mathrm{~Hz}$ 
single pulse

F:\SAA論文 $\backslash$ NMR $\backslash$ muchikan OPiv OPMB olefin proton-1-1.als

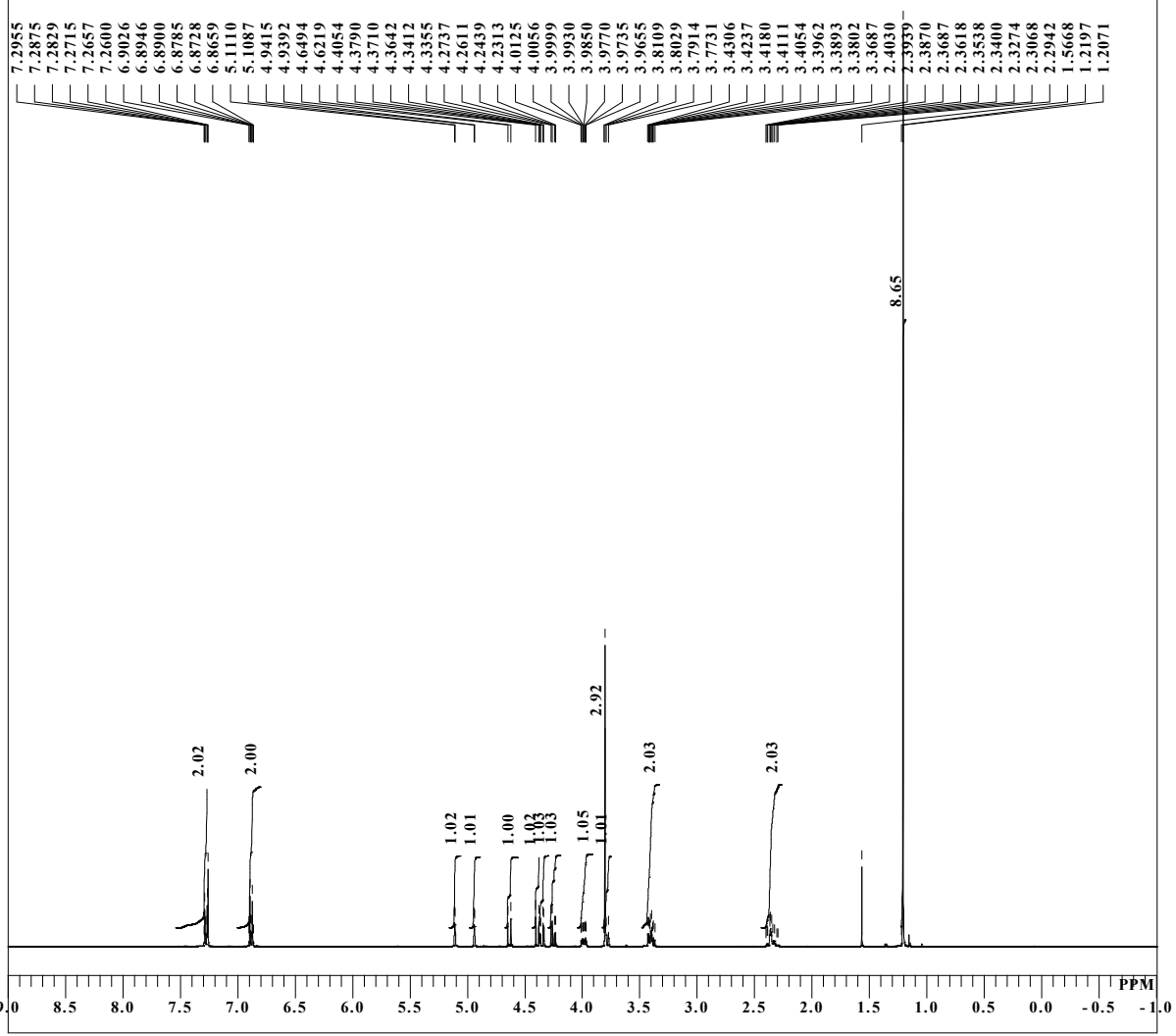

DFILE

COMNT
DATIM

OBNUC

EXMOD
OBFRQ
OBSET

OBSET

OBFIN

FREQU

ACQTM
PD

PD1

IRNUC
CTEMP

SLVNT

EXREF

RGAIN

archikan OPiv OPMB olefin proton-1single pulse $15: 13: 09$

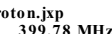

$399.78 \mathrm{MH}$
$4.19 \mathrm{KHz}$

$4.79 \mathrm{KHz}$
$7.29 \mathrm{~Hz}$

13107
6002.40

$6002.40 \mathrm{H}$
11

$2.1837 \mathrm{sec}$
$1.0000 \mathrm{sec}$

$1 \mathrm{H} \quad 7.25$ use

20.9
CDCL3

$7.26 \mathrm{ppm}$
$0.12 \mathrm{~Hz}$

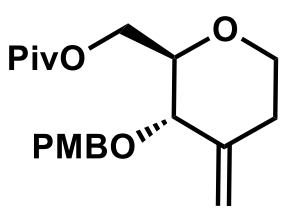

13

$87 \%$ in 2 steps

single pulse decoupled gated NOE

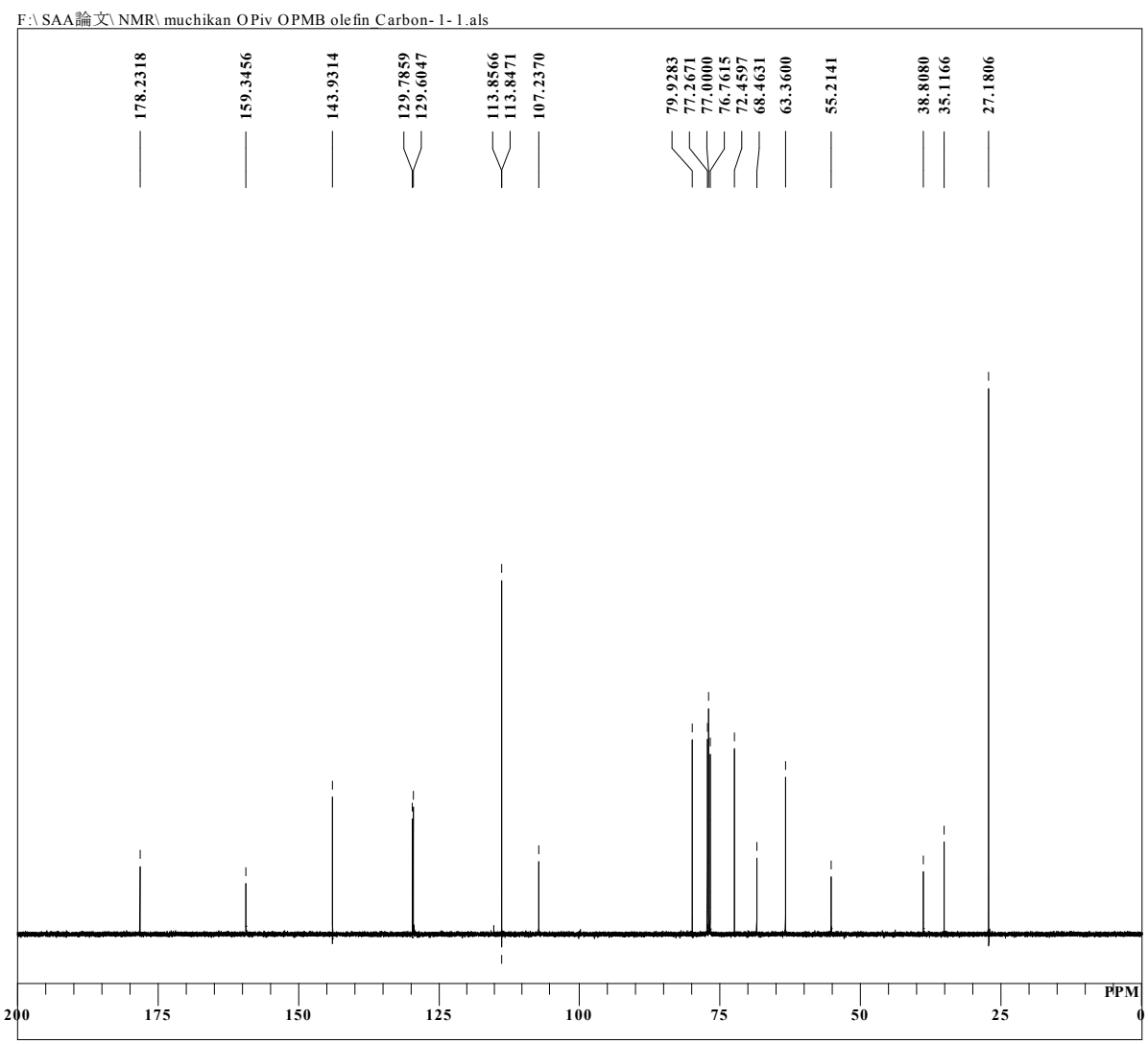

single pulse decoupled gated $\mathrm{NOE}$

DATIM

OBSET
OBFIN

POINT

FREQ

ACQTM

PD

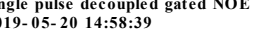

125.77 MHz

$7.87 \mathrm{KHz}$

$7.87 \mathrm{KH} 2$
$4.21 \mathrm{~Hz}$

26214

$31446.54 \mathrm{~Hz}$

$0.8336 \mathrm{sec}$
$\mathbf{3 . 0 0 0 0} \mathrm{sec}$

1H 3.27 usec

CTEMP 20.5

$\begin{array}{ll}\text { SLVNT } & \text { CDCL3 } \\ \text { EXREF } & 77.00 \mathrm{ppm}\end{array}$

$\begin{array}{lc}\text { BXREF } & \mathbf{1 2} \mathrm{Hz} \\ \text { RGAIN } & 60\end{array}$ 
single_pulse

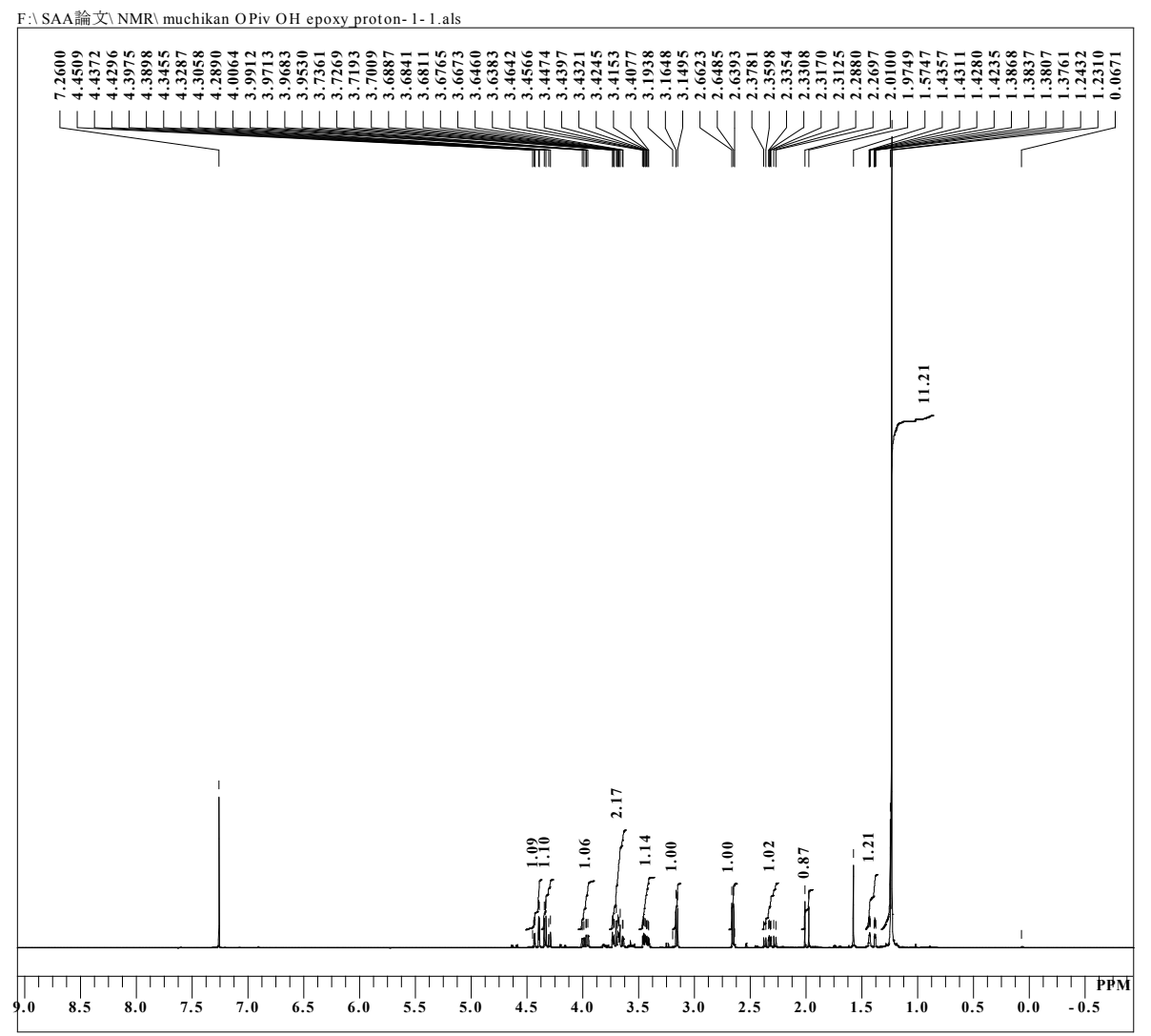

DFILE

COMNT
DATIM

OBNUC

EXMOD
OBFRQ
OBSET

OBSET

POINT

FCANS

SCANS
ACQTM
PD

PW1

IRNUC

SLENT
EXREF

EXREF

RGAIN

kan $\mathrm{OPiv}$ OH epoxy proton-1-1.

single pulse 12:10:26

$300.53 \mathrm{MHz}$
3.j.

$1.15 \mathrm{KHz}$

$1.15 \mathrm{KHz}$
$8.57 \mathrm{~Hz}$

13107
6016.85
173

6016.85
13

$2.1784 \mathrm{sec}$
$1.0000 \mathrm{sec}$

$1 \mathrm{H} \quad 5.50 \mathrm{usec}$

$19.7 \mathrm{c}$
CDCL3

L3
$7.26 \mathrm{ppm}$
$0.12 \mathrm{~Hz}$
40

Piv<smiles>O[C@H]1[C@H](CO[AlH2])OCC[C@]12CO2</smiles>

21

$82 \%$ in 2 steps

single pulse decoupled gated NOE

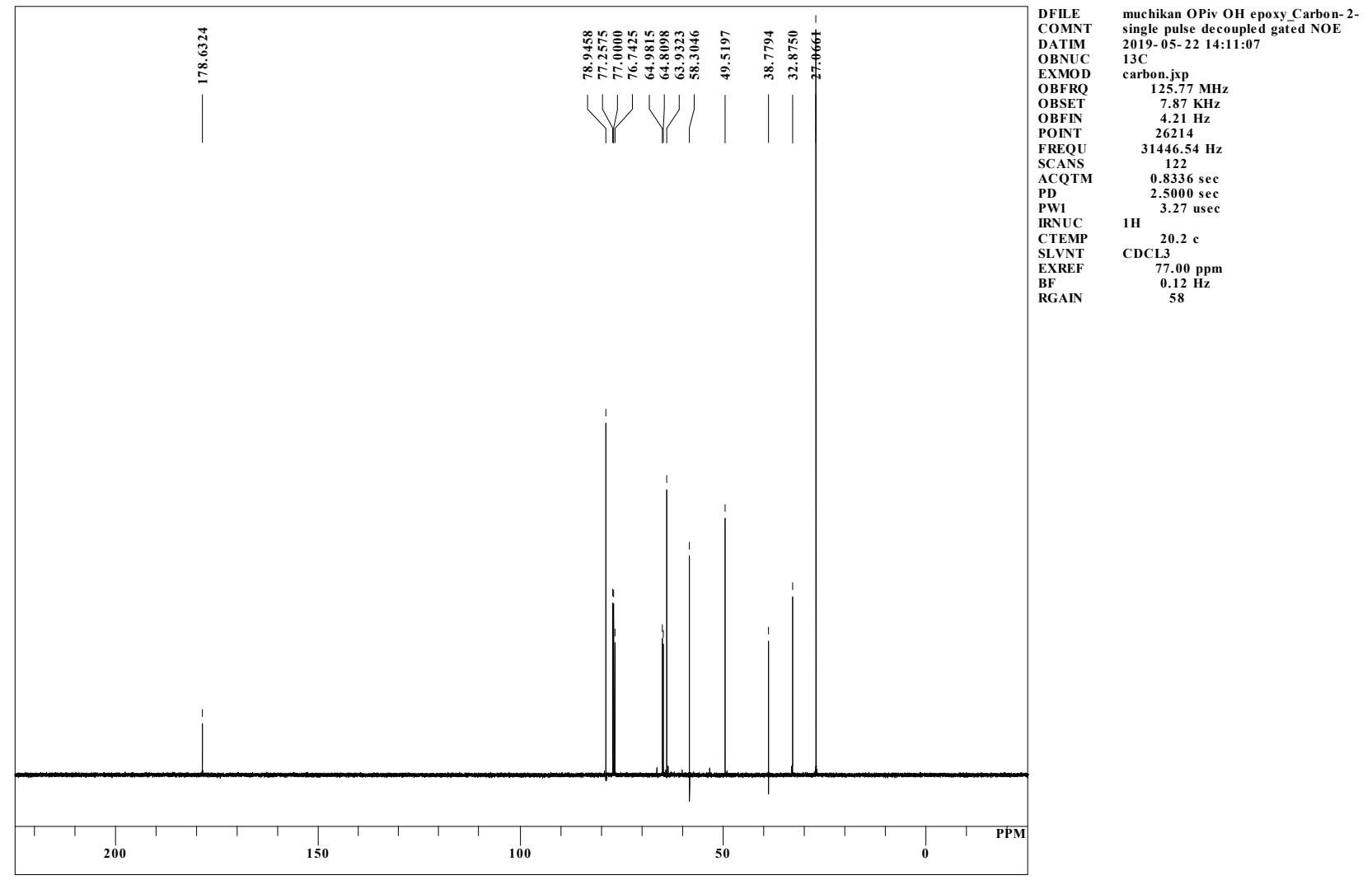


single pulse

F: $\backslash$ SAA論文 $\backslash$ NMR $\backslash$ muchikan OH OTBS epoxy proton-1-1.als

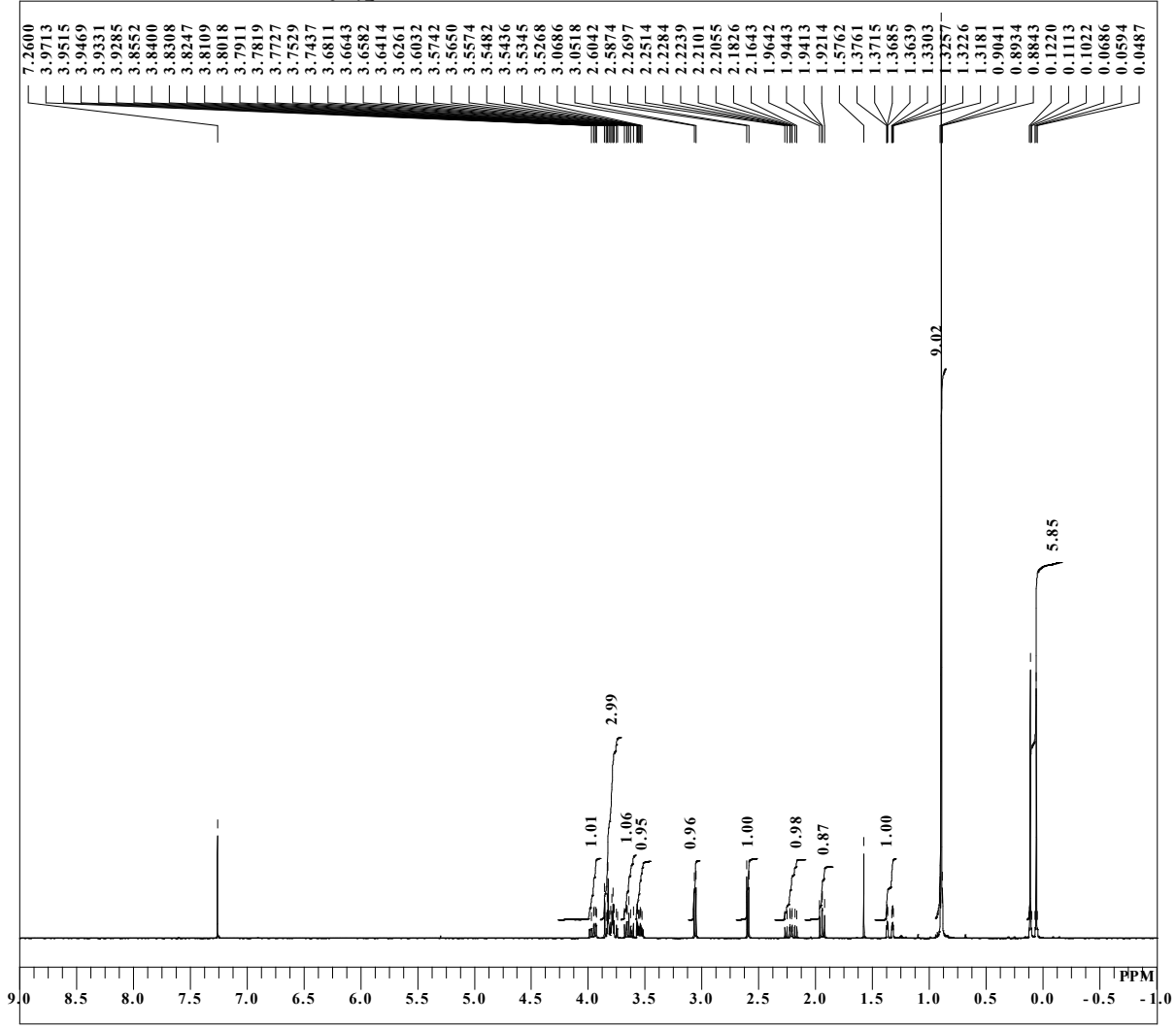

DFILE

COMNT
DATIM

OBNUC
EXMOD

EXMOD
OBFRQ
OBSET

OBSET

OBFIN

POINT

SCANS

PD

PW1

IRNUC
CTEMP

SLVNT

EXREF
BF

muchikan OH OTBS epoxy proton- 1- 1

single pulse
2019-05-23 15:42:23

$1 \mathrm{H}$

roton.jxp

$1.15 \mathrm{KHz}$

$1.15 \mathrm{KHz}$
$8.57 \mathrm{~Hz}$

13107
6016.85
172

6016.85
16

$2.1784 \mathrm{sec}$
$1.0000 \mathrm{sec}$

$1 \mathrm{H} \quad 5.50$ use

20.1
CDCL3

$7.26 \mathrm{ppm}$
$0.12 \mathrm{~Hz}$
38

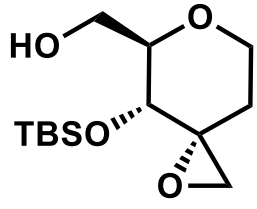

24

$59 \%$ in 2 steps

single pulse decoupled gated NOE

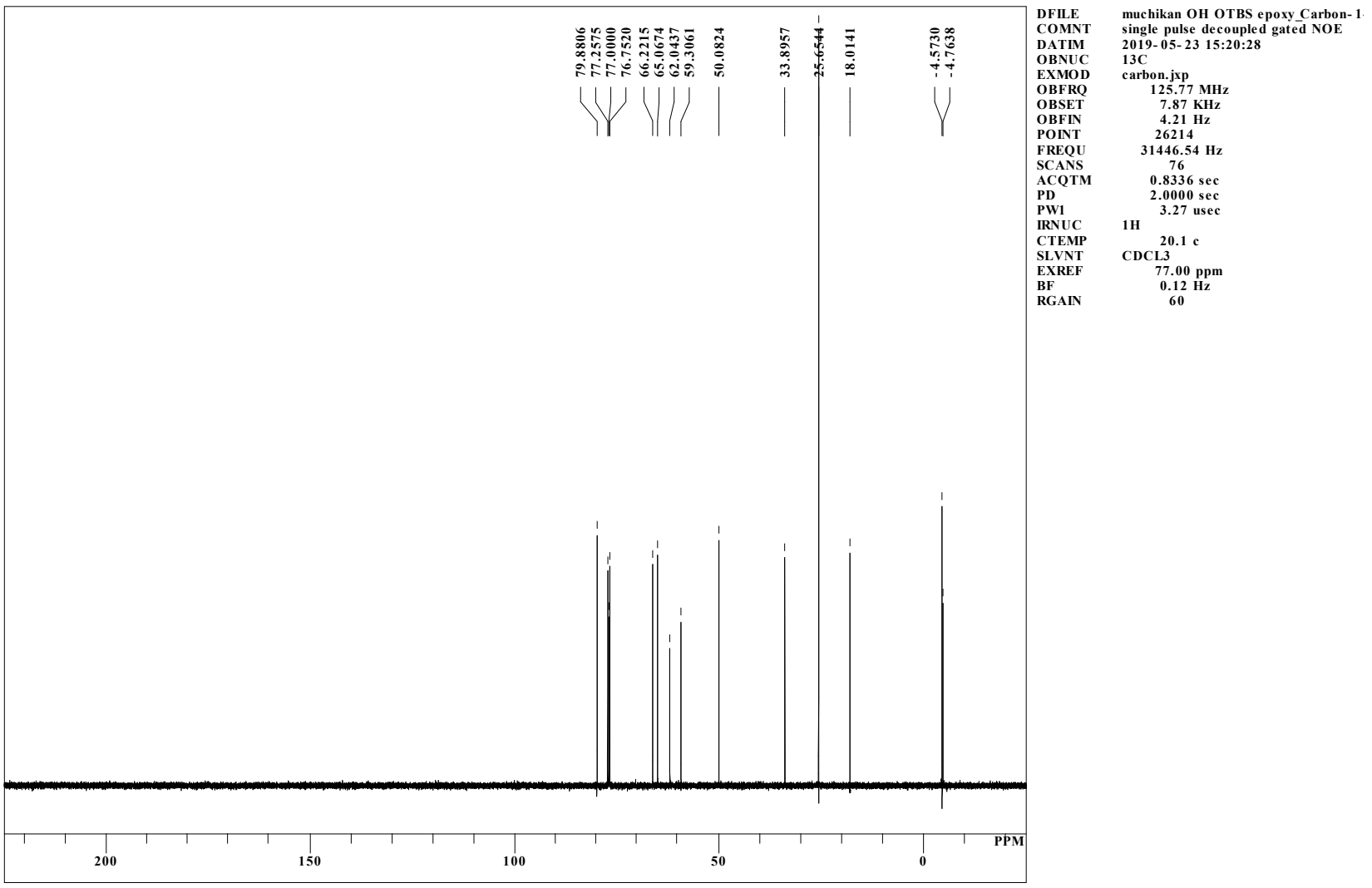


single _pulse

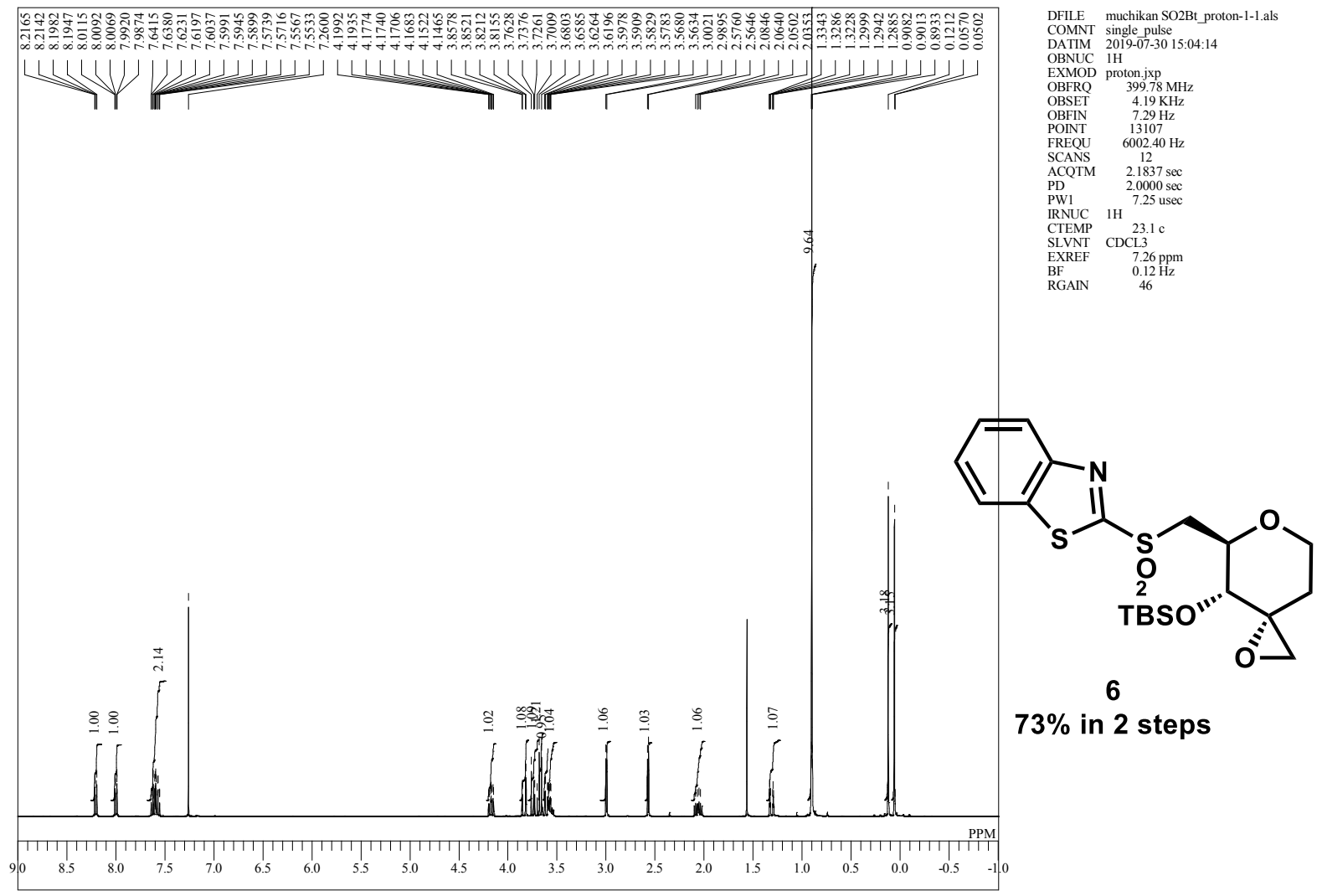

single pulse decoupled gated NOE

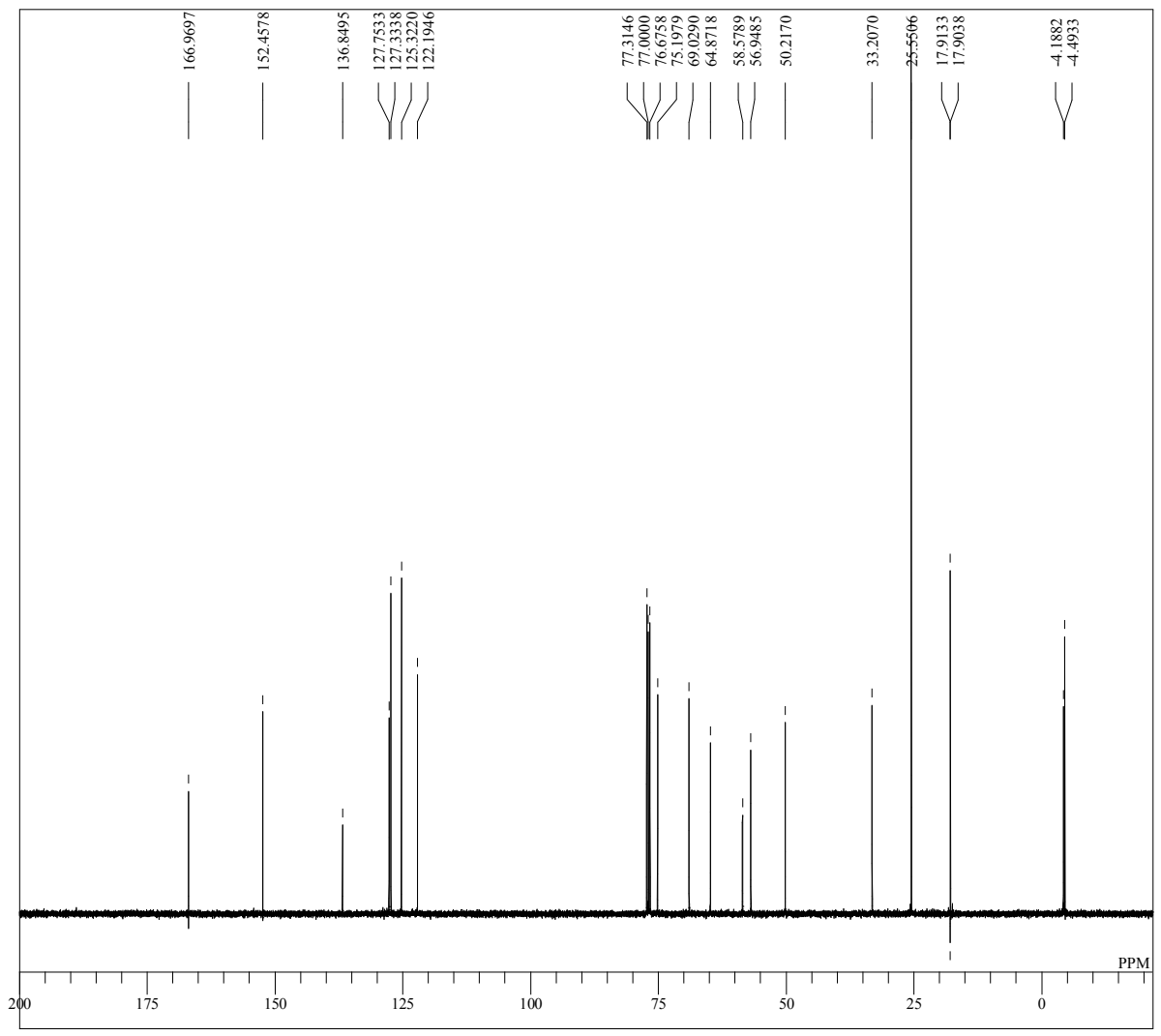

$\begin{array}{ll}\text { DFILE } & \text { muchikan SO2Bt carbon-1-1.als } \\ \text { COMNT } & \text { single pulse decoupled gated NOE }\end{array}$

OBNUC $13 \mathrm{C}$
EXMOD carbon

OBFRQ $\quad 100.53 \mathrm{MHz}$

OBSET $\quad 5.35 \mathrm{KHz}$

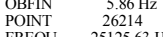

$\begin{array}{lc}\text { FREQU } & 25125.63 \mathrm{~Hz} \\ \text { SCANS } & 372\end{array}$

$\begin{array}{lc}\text { SCANS } & 372 \\ \text { ACQTM } & 1.0433 \mathrm{sec}\end{array}$

PW1 $\quad 3.17$ usec

$\begin{array}{lll}\text { IRNUC } & 1 \mathrm{H} & \\ \text { CTEMP } & & \\ 23.4 \mathrm{c}\end{array}$

$\begin{array}{ll}\text { CTEMP } & 23.4 \mathrm{c} \\ \text { SLVNT } & \text { CDCL3 }\end{array}$

$\begin{array}{lc}\text { EXREF } & 77.00 \mathrm{ppm} \\ \mathrm{BF} & 0.12 \mathrm{~Hz}\end{array}$

$7.26 \mathrm{ppm}$
$\mathrm{H}$ 
single pulse

F:\SAA論文 $\backslash$ NMR $\backslash$ muchikan normal HCl MeOH proton-1-1.als

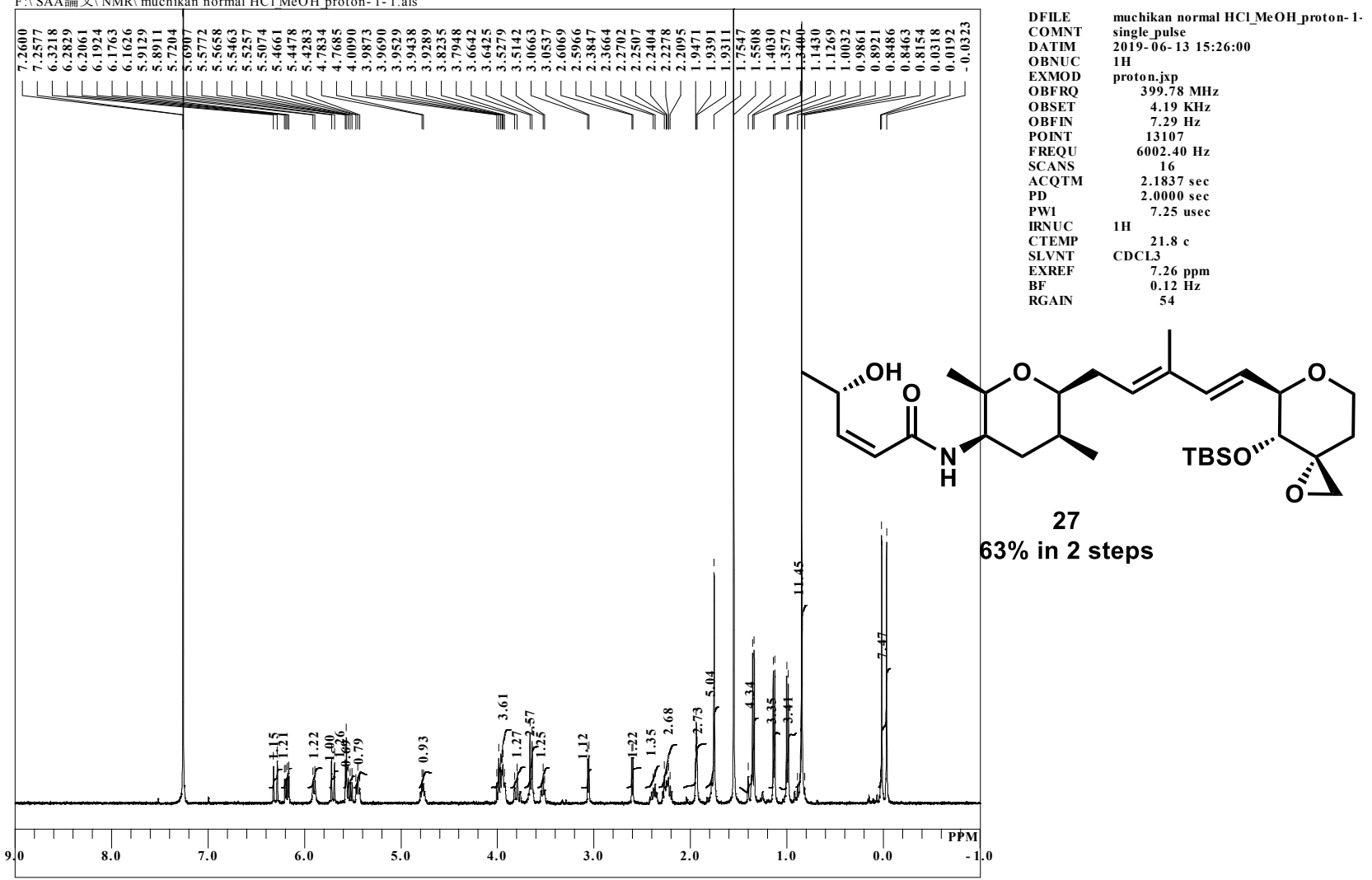

single pulse decoupled gated NOE

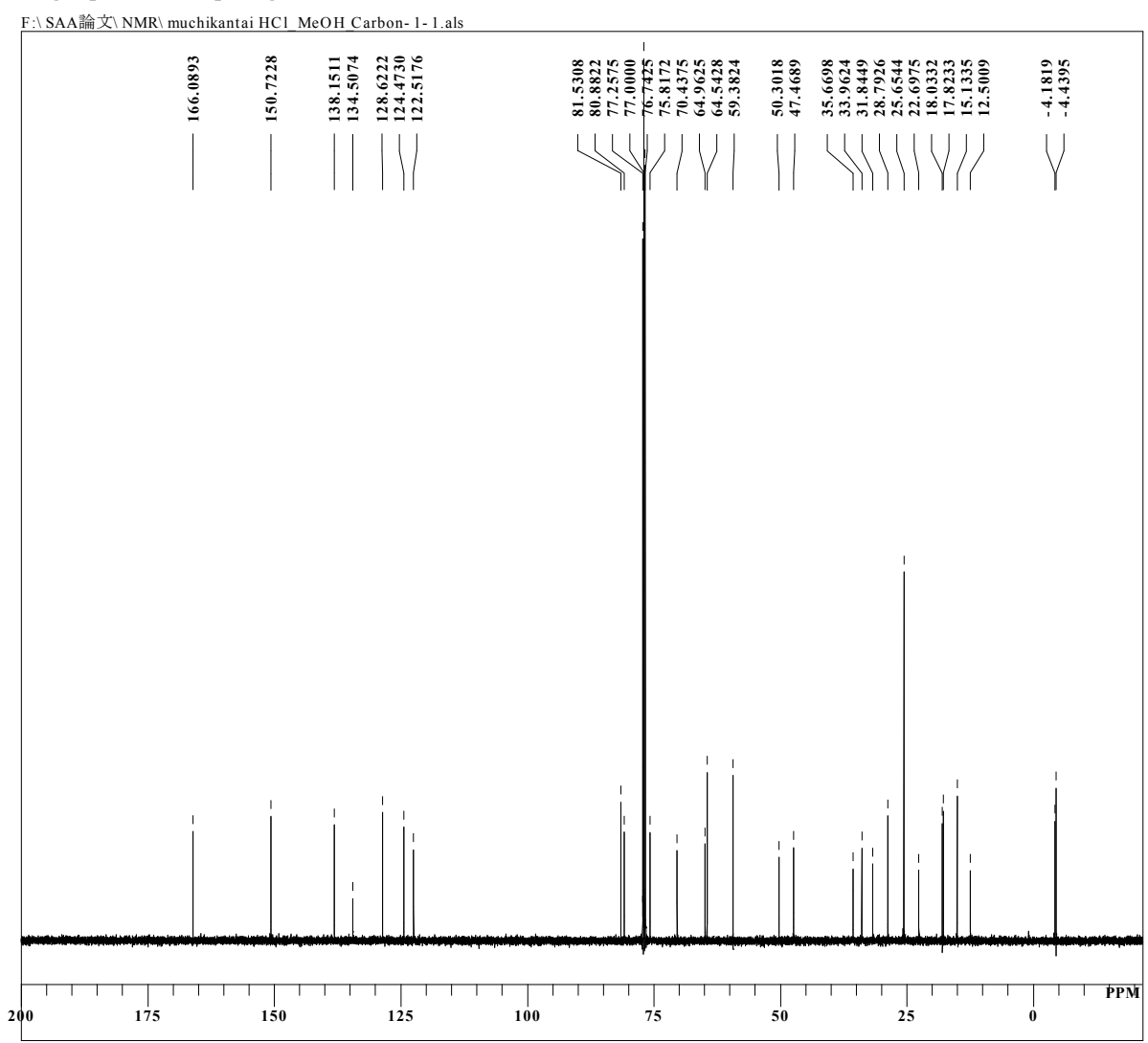

DFILE

COMNT single pulse decoupled gated NOE

DATIM

OXMOD
OBFRQ

OBFRQ $\quad 125.77 \mathrm{MH} z$

$\begin{array}{ll} & 7.87 \mathrm{KHz} \\ \text { OBSET } & 4.21 \mathrm{~Hz}\end{array}$

26214

31446.54
$\mathrm{HZ}$

$\begin{array}{ll}\text { ACQTM } & 0.8336 \mathrm{sec} \\ \mathrm{PD} & 2.0000 \mathrm{sec}\end{array}$

$\begin{array}{ll}\text { PW1 } & 3.27 \text { usec }\end{array}$

$\begin{array}{lll}\text { IRNUC } & 1 \mathrm{H} & \mathbf{2 0 . 9} \\ \text { CTEMP } & & 20.9\end{array}$

$\begin{array}{lc}\text { CTEMP } & 20.9 \mathrm{c} \\ \text { SLVNT } & \text { CDCL3. } \\ \text { EXREF } & 77.00 \mathrm{pp}\end{array}$

$\begin{array}{lc}\text { EXREF } & 77.00 \mathrm{ppm} \\ \text { BF } & 0.12 \mathrm{~Hz}\end{array}$

60 
single pulse

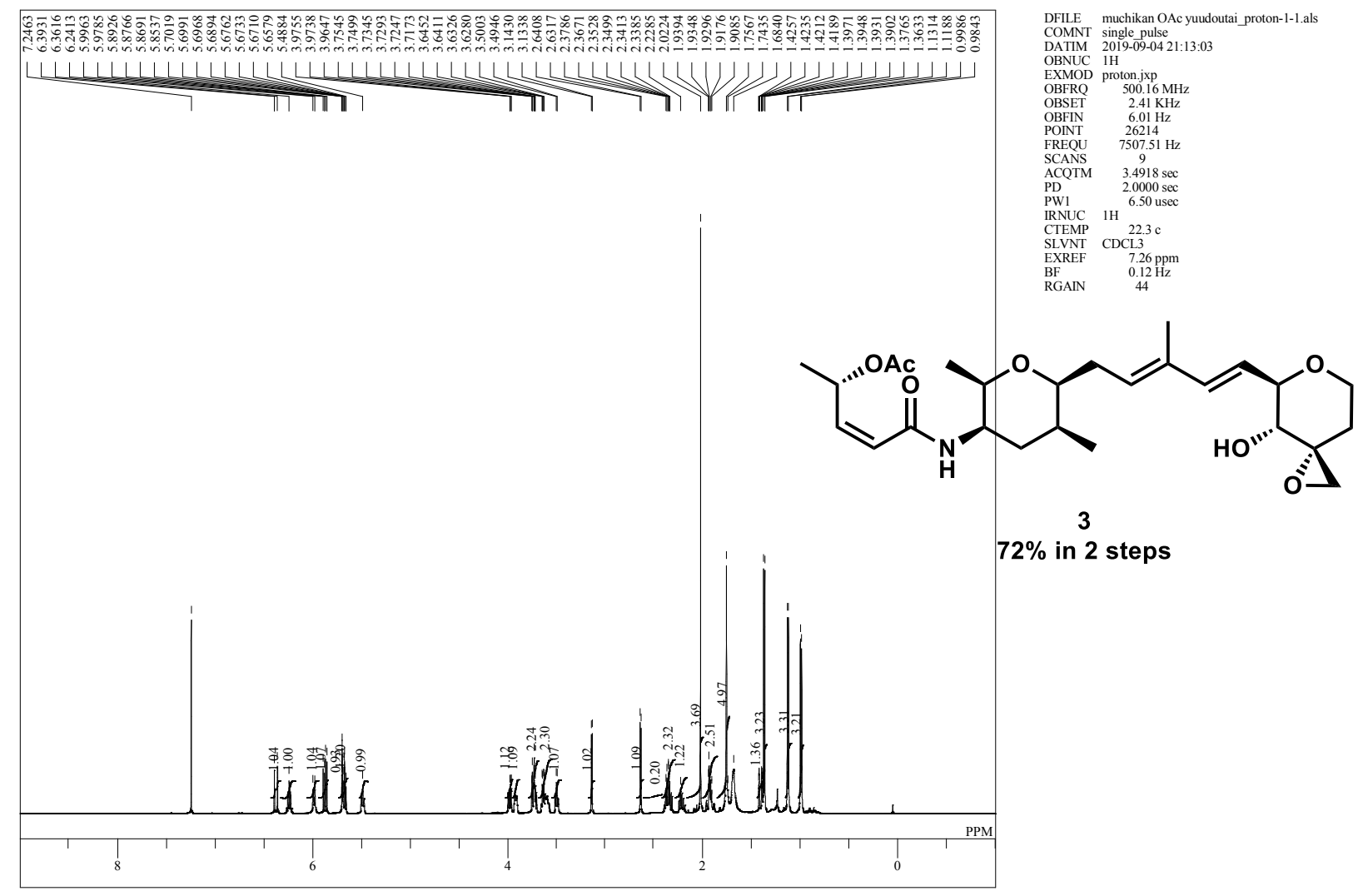

single pulse decoupled gated NOE

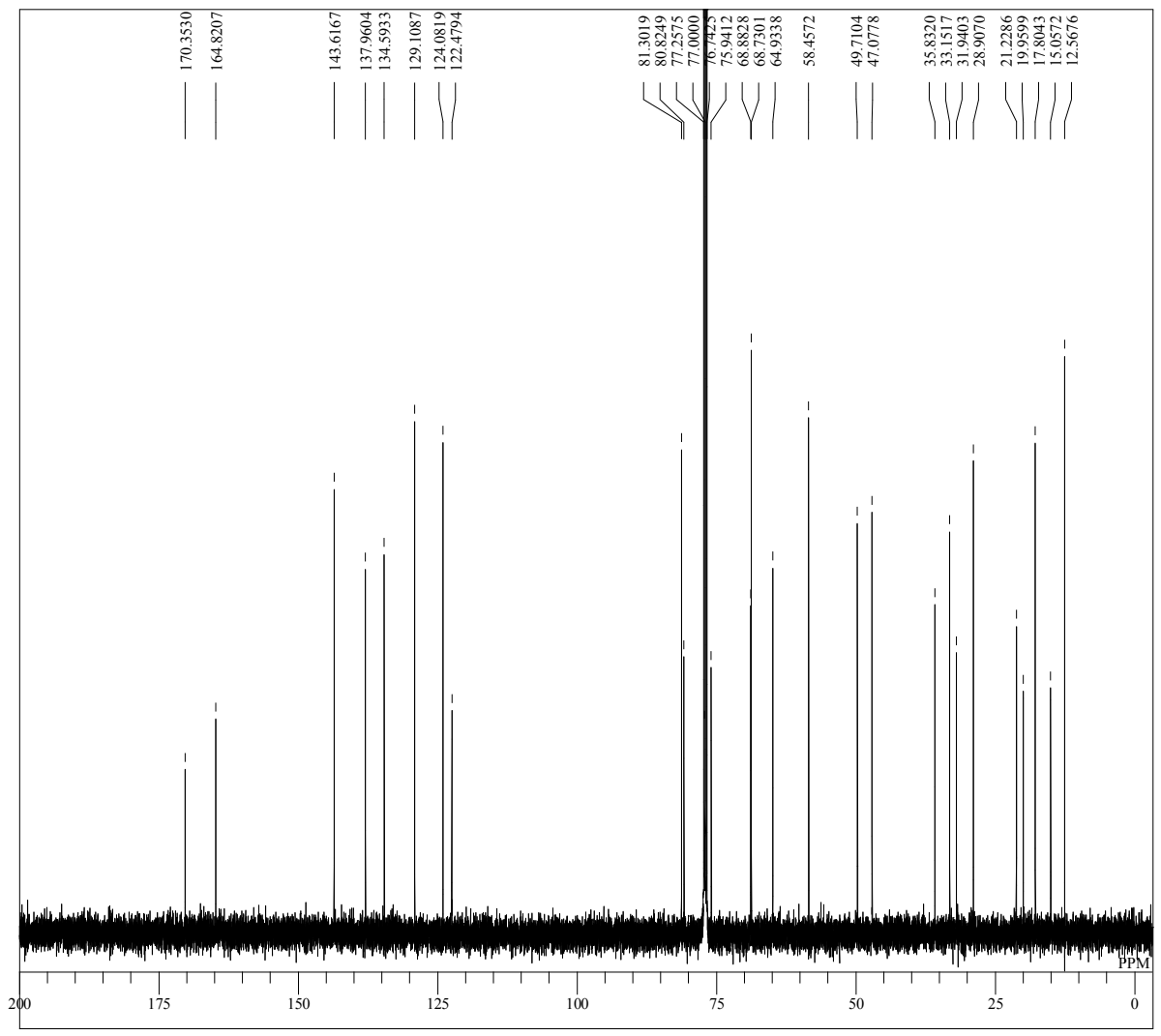

DFILE muchikan OAc yuudoutai Carbon-1-1.als

COMNT single pulse decoupled gated NOE

OBNUC 13C

EXMOD carbon.jxp

OBSET $\quad 7.87 \mathrm{KHz}$

OBFIN

FREQU $\quad 31446.54 \mathrm{H} z$

$\begin{array}{lll}\text { SCANS } & 2898 \\ \text { ACQTM } & 08336\end{array}$

$\begin{array}{ll}\text { PD } & 0.8336 \mathrm{sec} \\ \mathrm{PW1} & 1.000 \mathrm{sec} \\ \mathrm{PW} & 3.27 \mathrm{usec}\end{array}$

IRNUC $1 \mathrm{H}$

STEMPT 22.6

$\begin{array}{lc}\text { EXREF } & 77.00 \mathrm{ppm} \\ \mathrm{BF} & 0.12 \mathrm{~Hz}\end{array}$ 
single_pulse

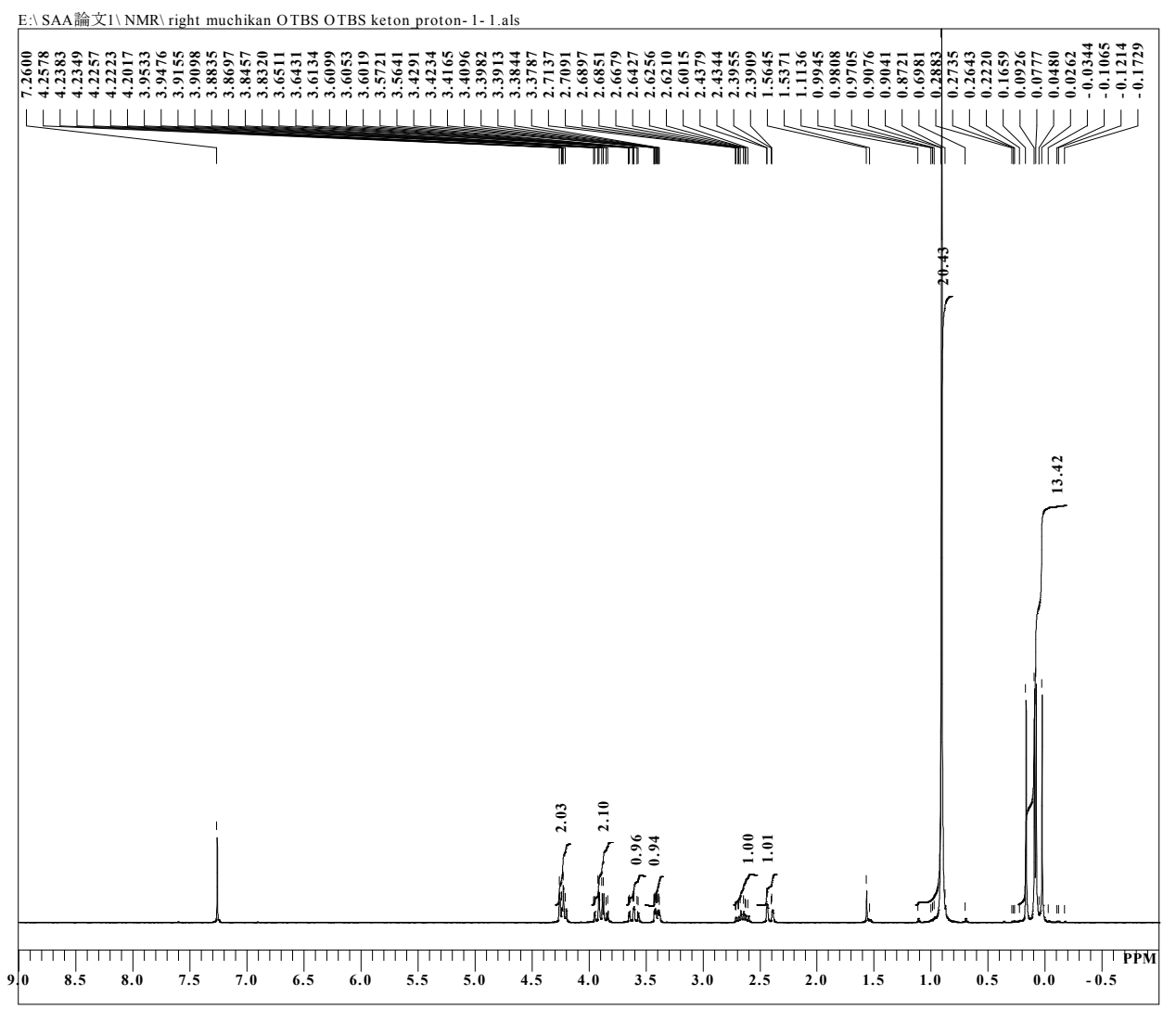

DFILE right muchikan OTBS OTBS keton pr

COMN

DATIM

OBNUC

EXMOD
OBFRQ

OBFRQ
OBSET
OBFIN

POINT

FREQU
SCANS

ACQTM
PD

PW1

IRNUC

SLVNT

EXREF 2020-02-04 22:00:52

proton.jxp

$300.53 \mathrm{MHz}$
$1.15 \mathrm{KHz}$

$1.15 \mathrm{KHz}$
$8.57 \mathrm{~Hz}$

13107
4508.57

$12.57 \mathrm{H}$

12
$2.9072 \mathrm{sec}$
$2.0000 \mathrm{sec}$

(H.

${ }_{\text {CDCL3 }}^{17.8 ~ c}$

$7.26 \mathrm{ppm}$
$0.12 \mathrm{~Hz}$

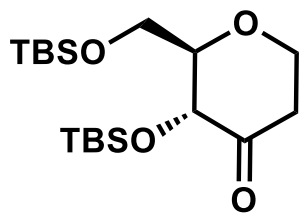

1

$95 \%$ in 2 steps

single pulse decoupled gated NOE

E: SAA論文 $1 \backslash$ NMR $\backslash$ right muchikan OTBS oTBS Carbon-1-1.als

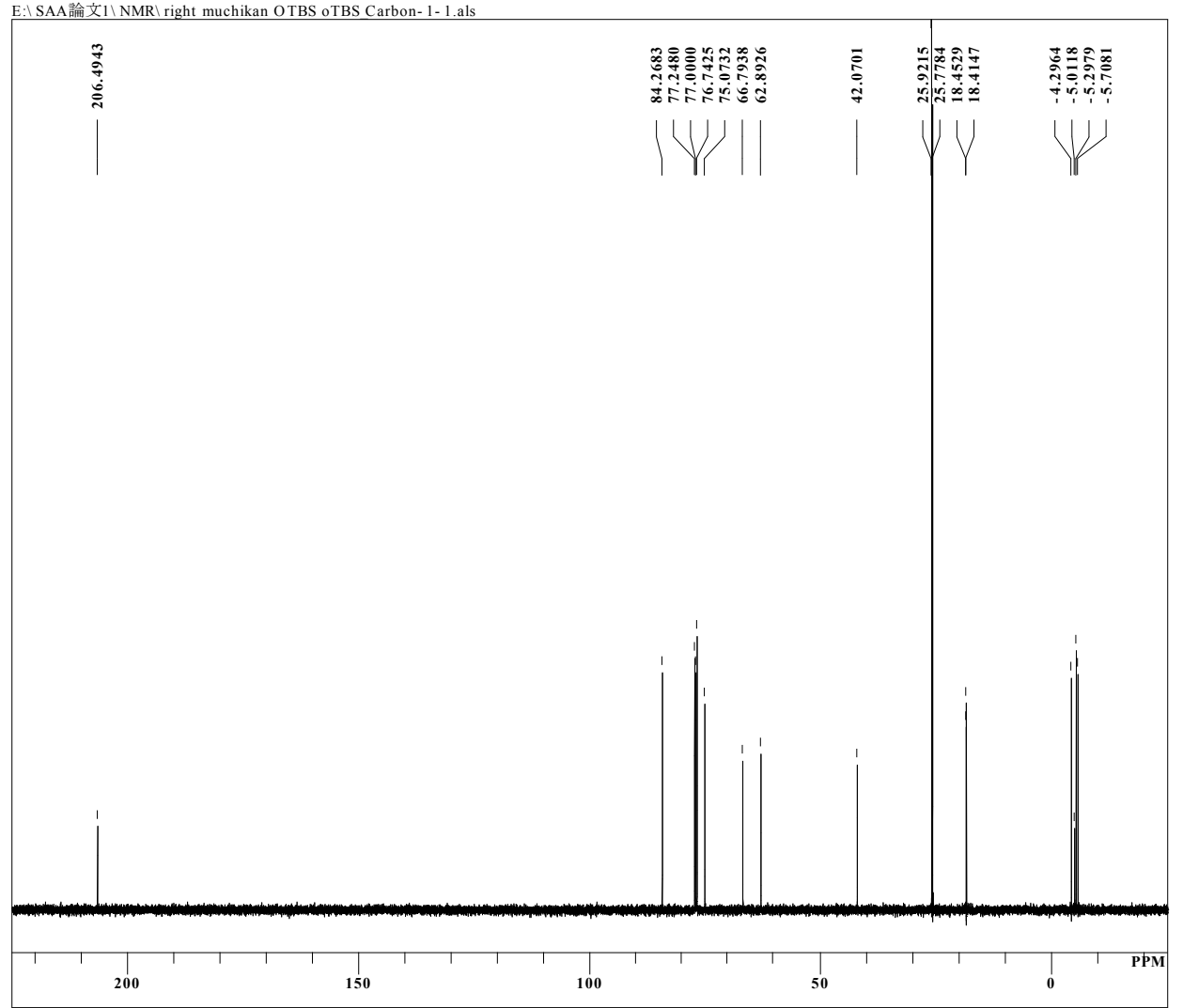

DFILE right muchikan OTBS OTBS Caron-1 COMNT single pulse decoupled gated NOE

$\begin{array}{ll}\text { EXMOD } & \text { carbon.jxp } \\ \text { OBFRQ } & 125.77 \mathrm{MHz}\end{array}$

$\begin{array}{ll}125.77 \mathrm{MH} / \\ \text { OBSET } & 7.87 \mathrm{KH} /\end{array}$

$\begin{array}{ll}\text { OBSET } & 7.87 \mathrm{KH} \\ \text { OBFIN } & 4.21 \mathrm{~Hz}\end{array}$

POINT $\quad 26214$

FREQU $\quad 31446.54$

ACQTM $\quad 0.8336 \mathrm{se}$

$\begin{array}{lr}\text { PD } & 2.0000 \mathrm{sec} \\ \text { PW1 } & 3.27 \text { usec }\end{array}$

$\begin{array}{lll}\text { IRNUC } & 1 \mathrm{H} & 3.5 \\ \text { CTEMP } & & \end{array}$

20.5
CLEMP

$\begin{array}{ll}\text { EXREF } & 77.00 \mathrm{ppm} \\ \text { BF } & 0.12 \mathrm{~Hz}\end{array}$

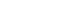

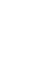


single pulse

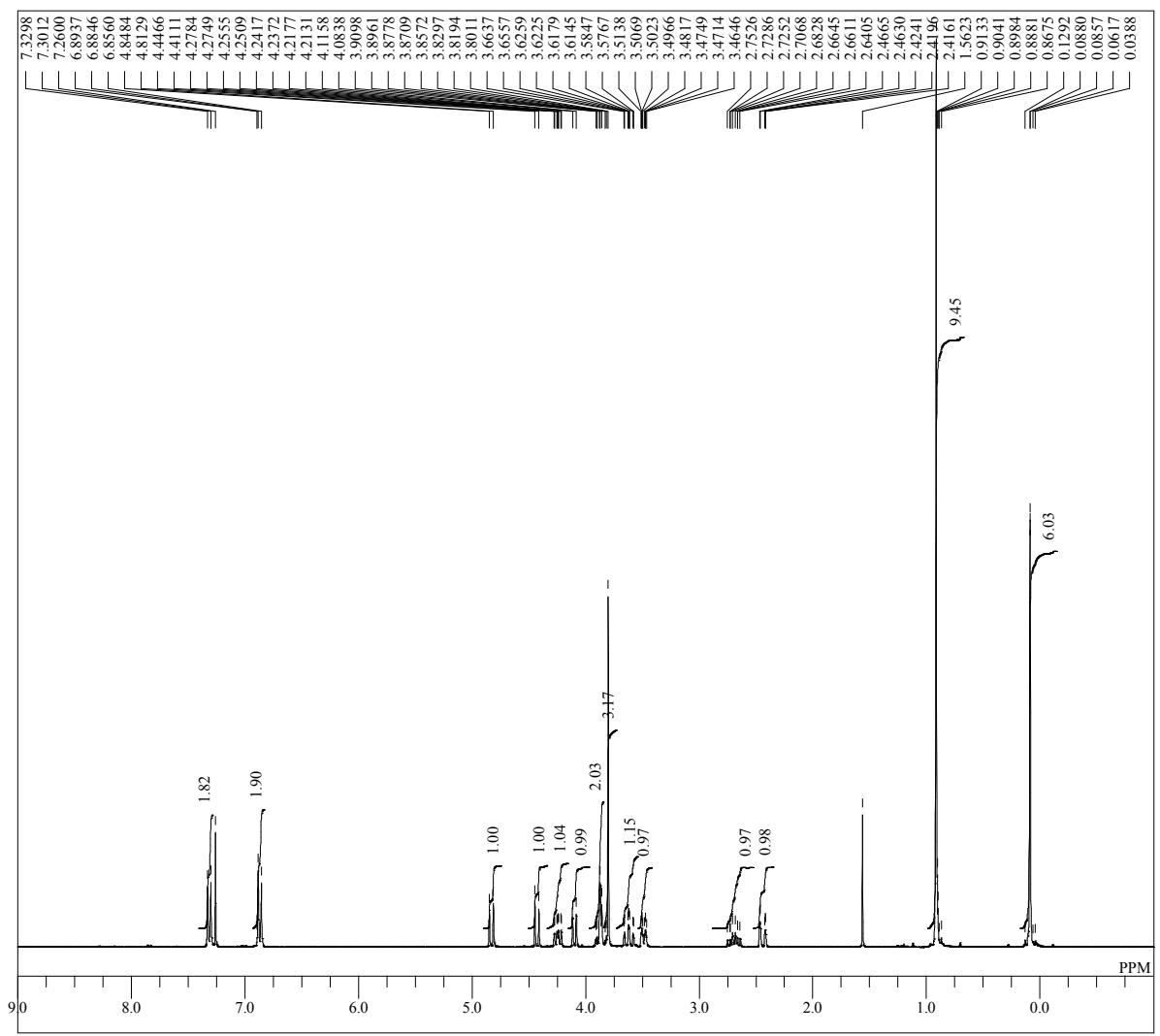

DFILE right muchikan OTBS OPMB keton proton-1-1.al COMNT
Dingle pulse
DATIM 2019-07-26 14:24:51 BNUC $1 \mathrm{H}$

EXMOD proton.jxp

$\begin{array}{ll}\text { OBRRQ } & 300.53 \mathrm{MH} \\ \mathrm{OBSET} & 1.15 \mathrm{KH} z\end{array}$

OBFIN

$\begin{array}{ll} & 13107 \\ & \text { FREQU } \\ 4508.57 \mathrm{~Hz}\end{array}$

SCANS 12

$\begin{array}{ll}\text { ACQTM } & 2.9072 \mathrm{sec} \\ \text { PD } & 1.0000 \mathrm{sec}\end{array}$

PW1 $1 \mathrm{RNUC} 5.50 \mathrm{usec}$

CTEMP 23.5

$\begin{array}{ll}\text { EXXEF } & 7.26 \mathrm{ppm} \\ \mathrm{BF} & 0.12 \mathrm{~Hz}\end{array}$

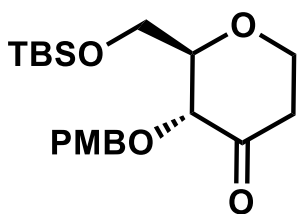

18

$64 \%$ in 3 steps

single pulse decoupled gated NOE

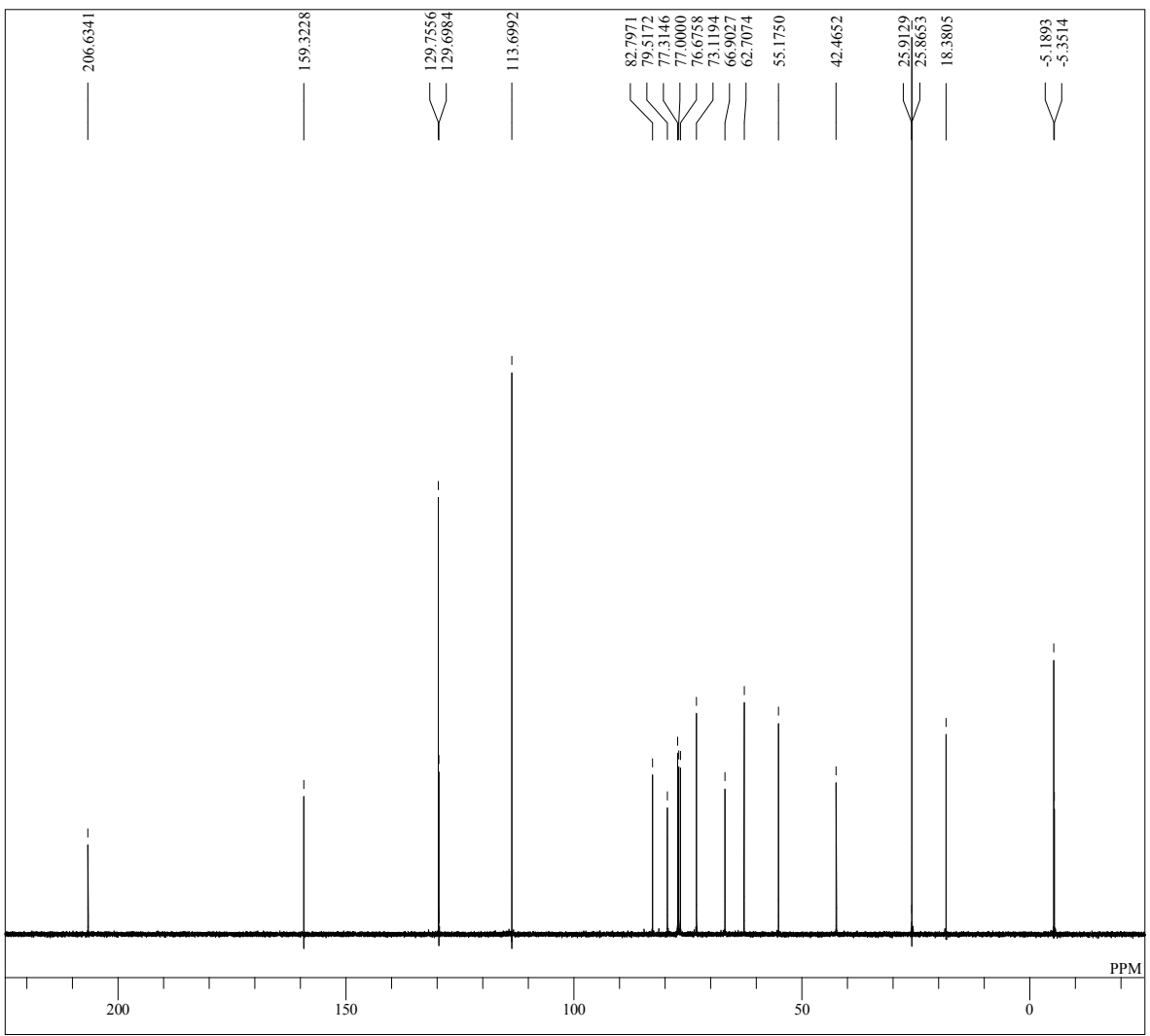

DFILE right muchikan OTBS OPMB keton carbon-1-1.al COMNT single pulse decoupled gated NOE

$\begin{array}{ll}\text { DATIM } & 2019-07.26 \\ \text { OBNUC } 13 \mathrm{C}\end{array}$

OBFRQ $\quad 100.53 \mathrm{MH}$

OBSET $\quad 5.35 \mathrm{KH} Z$

OBINT

FREQU $\quad 25125.63 \mathrm{H}$

SCANS 448

$\begin{array}{ll}\text { PD } & 1.0433 \mathrm{sec} \\ \mathrm{PW} & 1.0000 \mathrm{sec} \\ 3.17 \mathrm{usec}\end{array}$

IRNUC $1 \mathrm{H}$

CTEMP 23.1

$\begin{array}{ll}\text { EXREF } & 77.00 \mathrm{ppm} \\ \mathrm{BF} & 0.12 \mathrm{~Hz}\end{array}$ 
single pulse

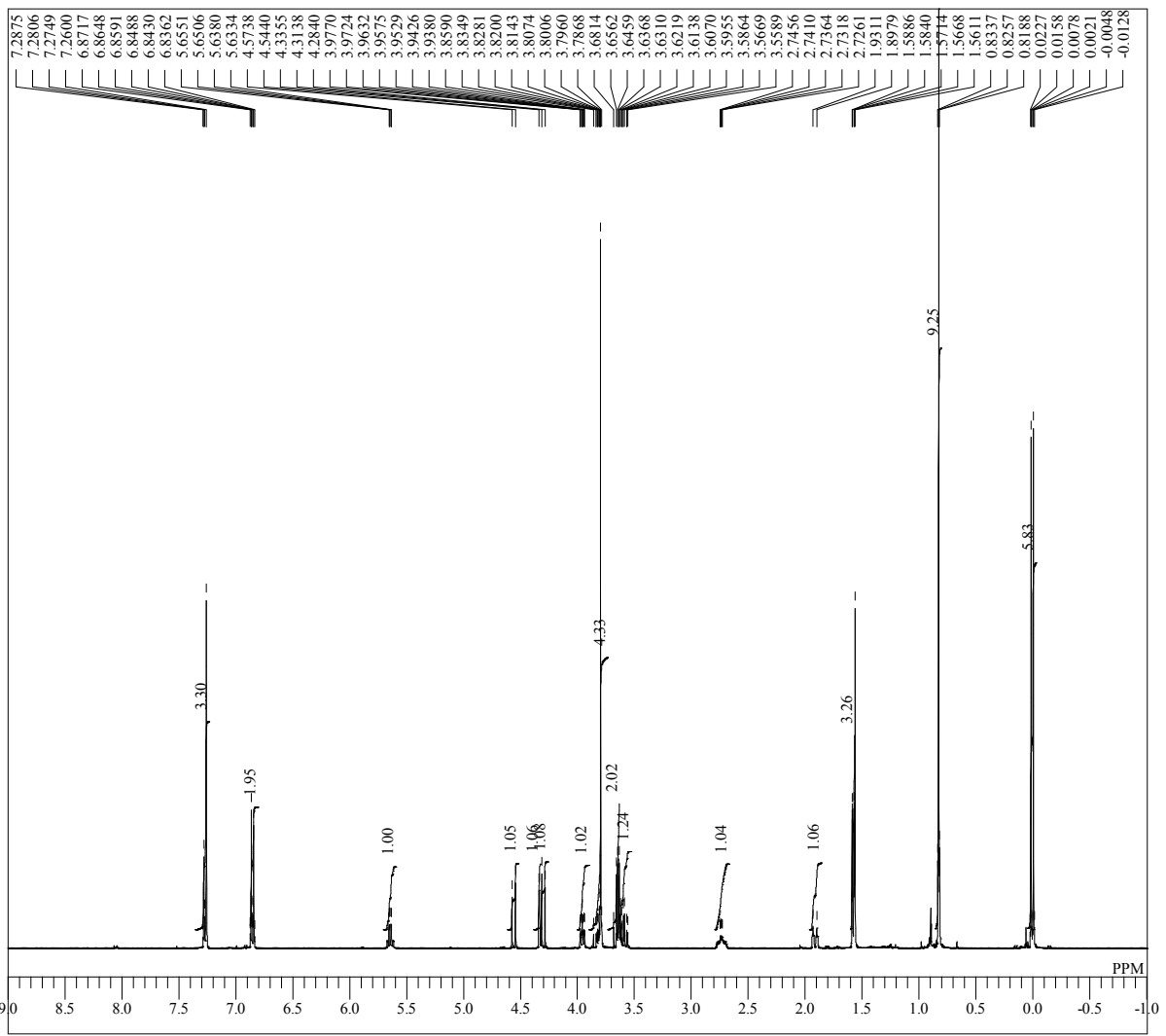

DFILE right muchikan OTBS OPMB etylolrfin shita proton $\begin{array}{ll}\text { DATIM } & \text { single pulse } \\ 2019-07-27 ~ 17: 43: 37\end{array}$ OBNUC $1 \mathrm{H}$

XMOD proton.jxp
OBFR
$399.78 \mathrm{MHz}$

$\begin{array}{ll}\mathrm{OBFRQ} & 399.78 \mathrm{MH} \\ \mathrm{OBSET} & 4.19 \mathrm{KHz}\end{array}$

OBFIN

FREQU $\quad 6002.40 \mathrm{~Hz}$

$\begin{array}{ll}\text { ACQTM } & 2.1837 \mathrm{sec} \\ \text { PD } & 1.0000 \mathrm{sec}\end{array}$

$\begin{array}{ll}\text { PW1 } & 7.25 \text { usec } \\ \text { IRNUC } & 1 \mathrm{H}\end{array}$

22.4c

$\begin{array}{ll}\text { EXREF } & 7.26 \mathrm{ppm} \\ \mathrm{BF} & 0.12 \mathrm{~Hz}\end{array}$

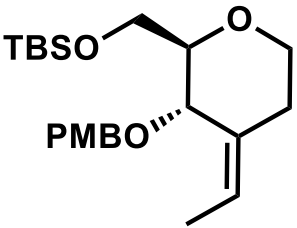

19

$47 \%$

single pulse decoupled gated NOE

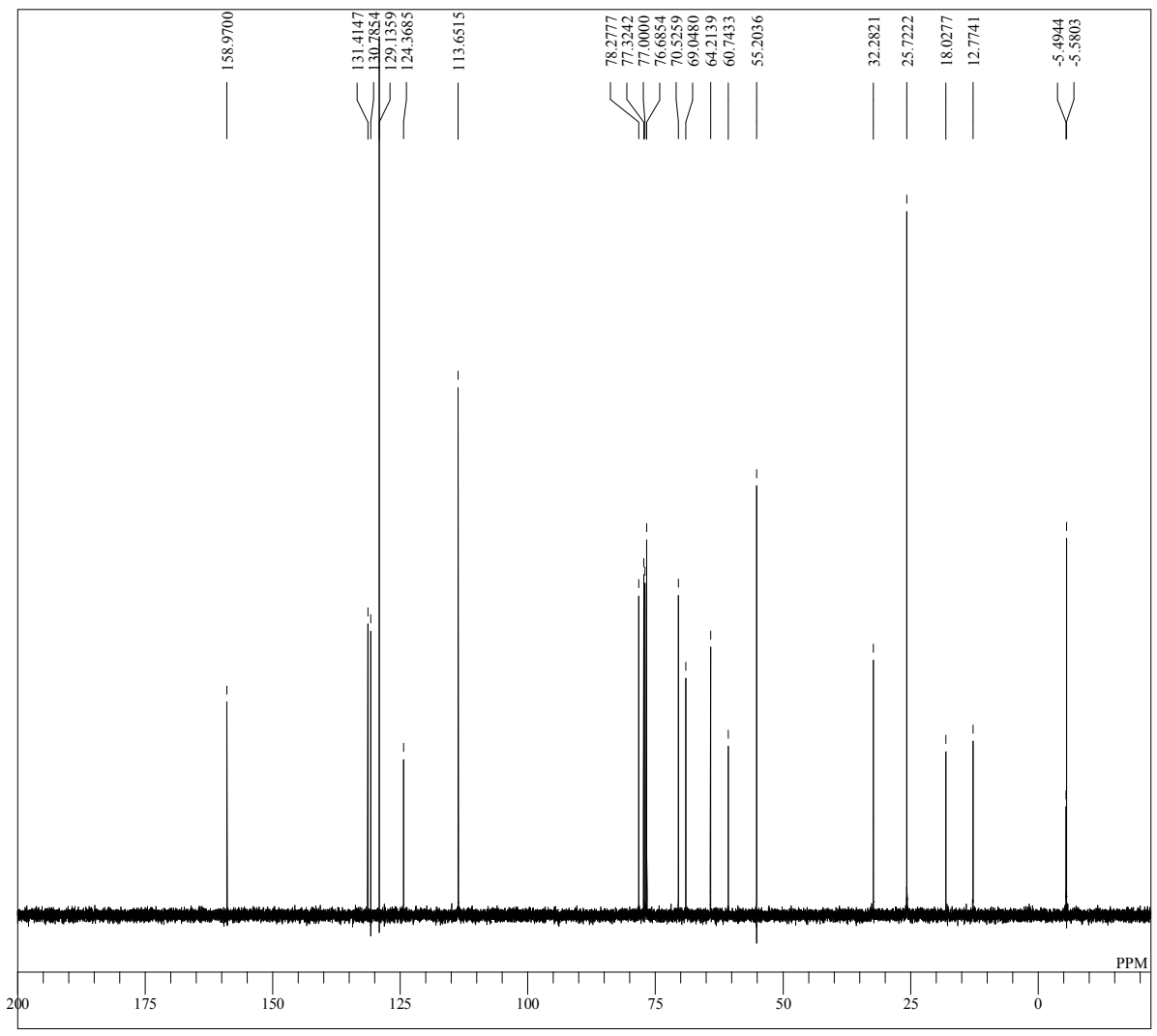

DFILE right muchikan OPMB OTBS etylolrfin shita carbon COMNT single pulse decoupled gated NOE

OBNUC 13C

OBFRQ carbon.jxp

$\quad 5.35 \mathrm{KH} z$

$\begin{array}{ll}\text { OBFIN } & 5.86 \mathrm{~Hz} \\ \text { POINT } & 26214\end{array}$

$\begin{array}{ll}\text { FREQU } & 25125.63 \mathrm{~Hz} \\ \text { SCANS } & 196\end{array}$

$\begin{array}{lc}\text { SCANS } & 196 \\ \text { ACQTM } & 1.0433 \mathrm{sec}\end{array}$

$\begin{array}{ll}\text { PD } & 1.0000 \mathrm{sec} \\ \text { PW1 } & 3.17 \mathrm{usec}\end{array}$

RNUC $1 \mathrm{H}$

$\begin{array}{ll}\text { CTEMP } & 22.8 \\ \text { SLVNT } & \text { CDCL3 }\end{array}$

$\begin{array}{ll}\text { SLVNT } & \text { CDCL3 } \\ \text { EXREF } & 77.00 \mathrm{ppm} \\ \mathrm{BF} & 0.12 \mathrm{~Hz}\end{array}$ 
single_pulse

F:\SAA論文 $\backslash$ NMR $\backslash$ muchikann OPiv OPMB etlyl olefin shita proton-1-1.als

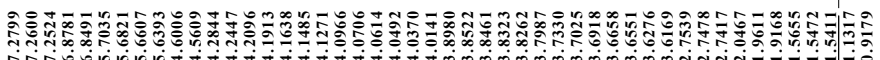

LLLLLLLLLLLLLLLLLLLLLLLU|JJ」J」JJ」J|J|J)|

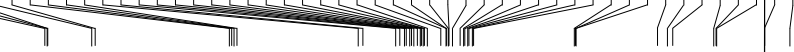

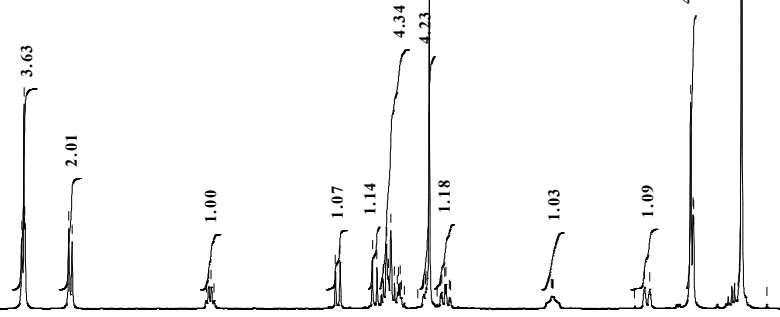

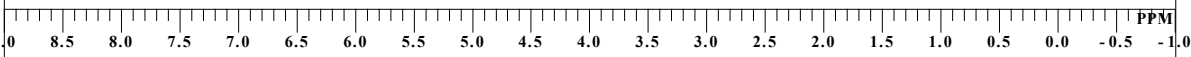

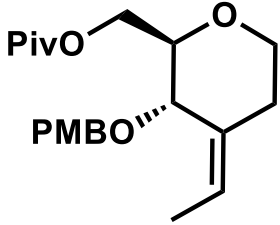

14

$59 \%$ in 2 steps

single pulse decoupled gated NOE

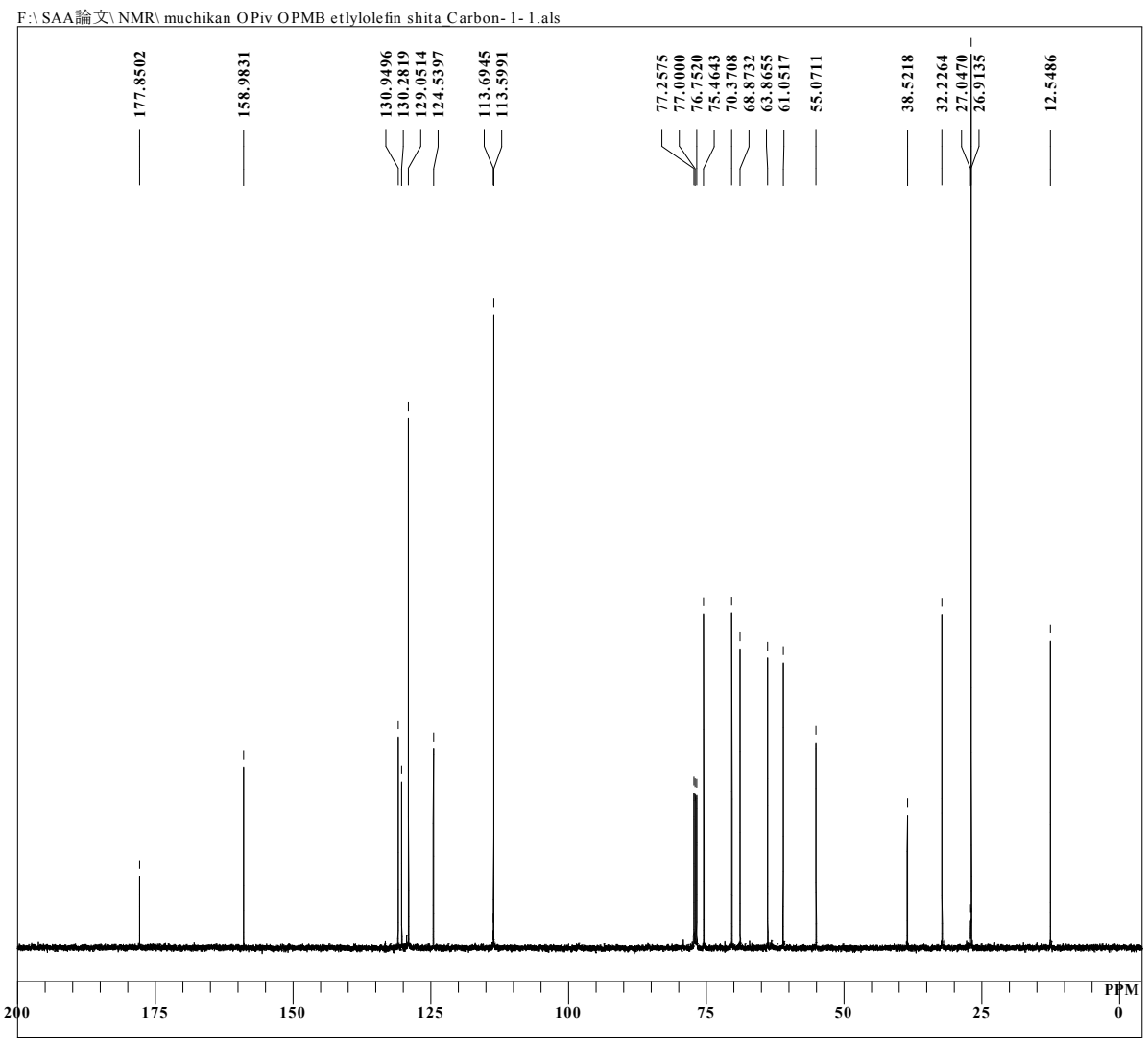

single pulse decoupled gated NOE

OBFRQ $\quad 125.77 \mathrm{MH} z$

$\begin{array}{ll}\text { BSET } & 7.87 \mathrm{KHz} \\ \text { BFIN } & 4.21 \mathrm{~Hz}\end{array}$

26214

CANS

$\begin{array}{ll}\text { ACQTM } & 0.836 \\ & 2.36 \mathrm{sec}\end{array}$

$\begin{array}{ll}\text { PD } & 2.0000 \mathrm{sec} \\ \text { PW1 } & 3.27 \text { usec }\end{array}$

PWN1 $1 \mathrm{H} \quad 3.27$ usec

\begin{tabular}{llc} 
IRNUC & $1 \mathrm{H}$ & $20.5 \mathrm{c}$ \\
CTEMP & \multicolumn{1}{c}{ CDCLO. } \\
SLVNT & CDCL3 \\
EXREF & $77.00 \mathrm{ppm}$
\end{tabular}

BF $\quad 1.20 \mathrm{~Hz}$

58 
single pulse

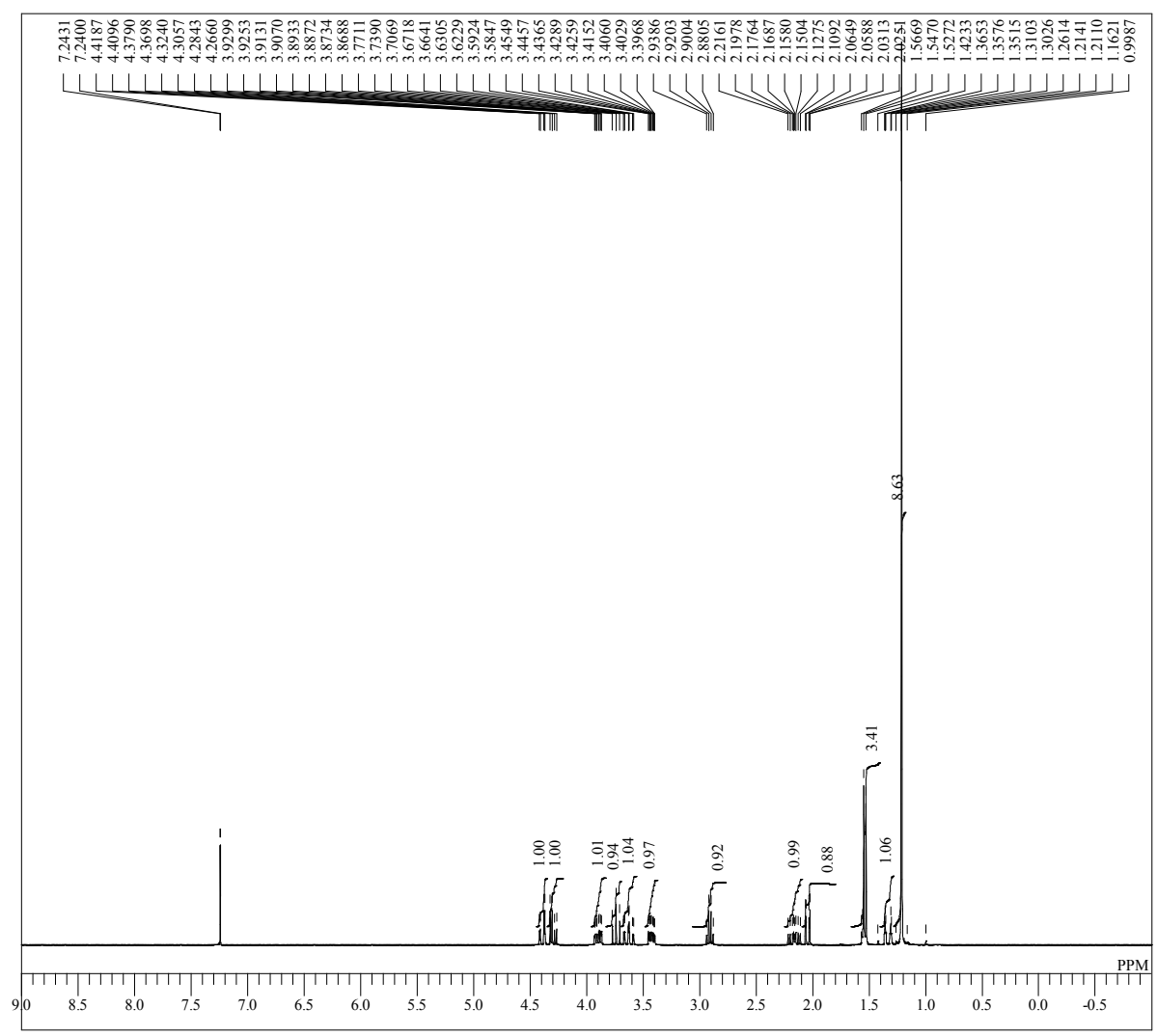

DFILE muchikan $\mathrm{OPiv} \mathrm{OH}$ ethylolefin shita proton-1-1.al $\begin{array}{ll}\text { COMNT } & \text { single pulse } \\ \text { DATIM } & \text { 2019-05-30 18:21:44 }\end{array}$ EXMOD $1 \mathrm{H}$

OBMOD proton.jxp

OBSET

OBFIN

$\begin{array}{ll} & 13107 \\ \text { FREQU } & 6016.85 \mathrm{H} Z\end{array}$

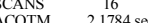

$\begin{array}{ll}2.1784 \mathrm{sec} \\ \mathrm{PD} & 1.0000 \mathrm{sec} \\ \mathrm{PW1} & 5.50 \mathrm{usec}\end{array}$

RNUC $1 \mathrm{H}$

20.50
CLEMNT CDCL3

$\begin{array}{ll}\text { EXREF } & 7.24 \mathrm{ppm} \\ \mathrm{BF} & 0.12 \mathrm{~Hz}\end{array}$

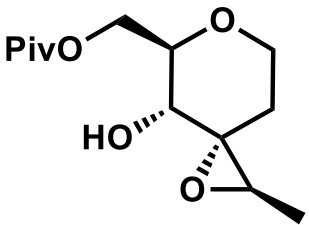

22

$95 \%$ in 2 steps

single pulse decoupled gated NOE

F:ISAA論文 $\backslash$ NMR $\backslash$ muchikan OPiv OH ethyl epoxy shita_Carbon-1-1.als

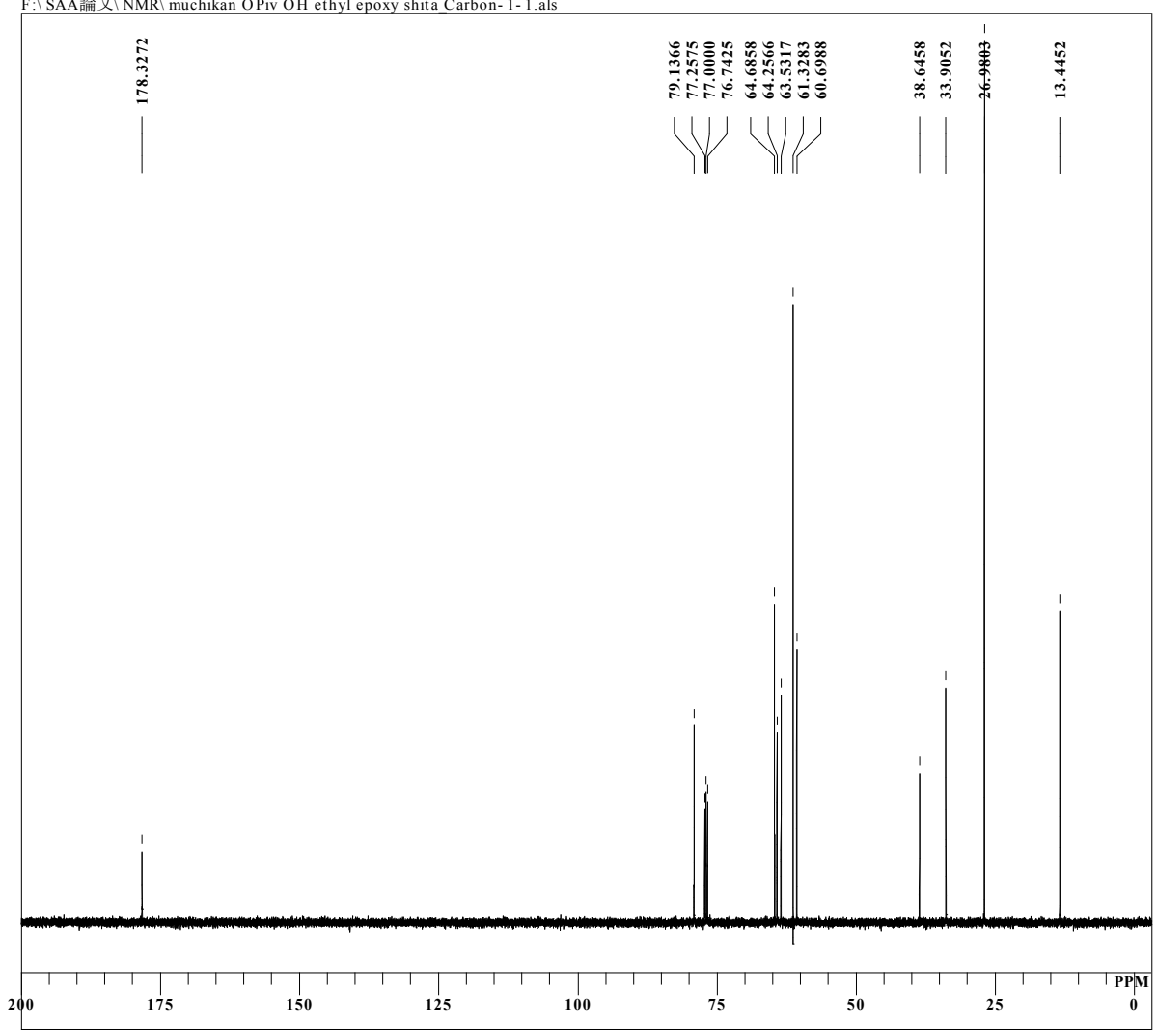

DFILE
COMNT

DATIM

OBNOC

OBSET

OBFIN

POIN

SCANS

PD

PW1

IRNUC
CTEMP

SLVNT
EXREF
BF

13C

$125.77 \mathrm{MHz}$
(2.87

$7.87 \mathrm{KHz}$

$7.21 \mathrm{~Hz}$
$\mathrm{~Hz}$

26214

$31446.54 \mathrm{~Hz}$

$0.8336 \mathrm{sec}$
$\mathbf{2 . 0 0 0 0} \mathrm{sec}$

$1 \mathrm{H}$

20.3
CDCL3 
single_pulse

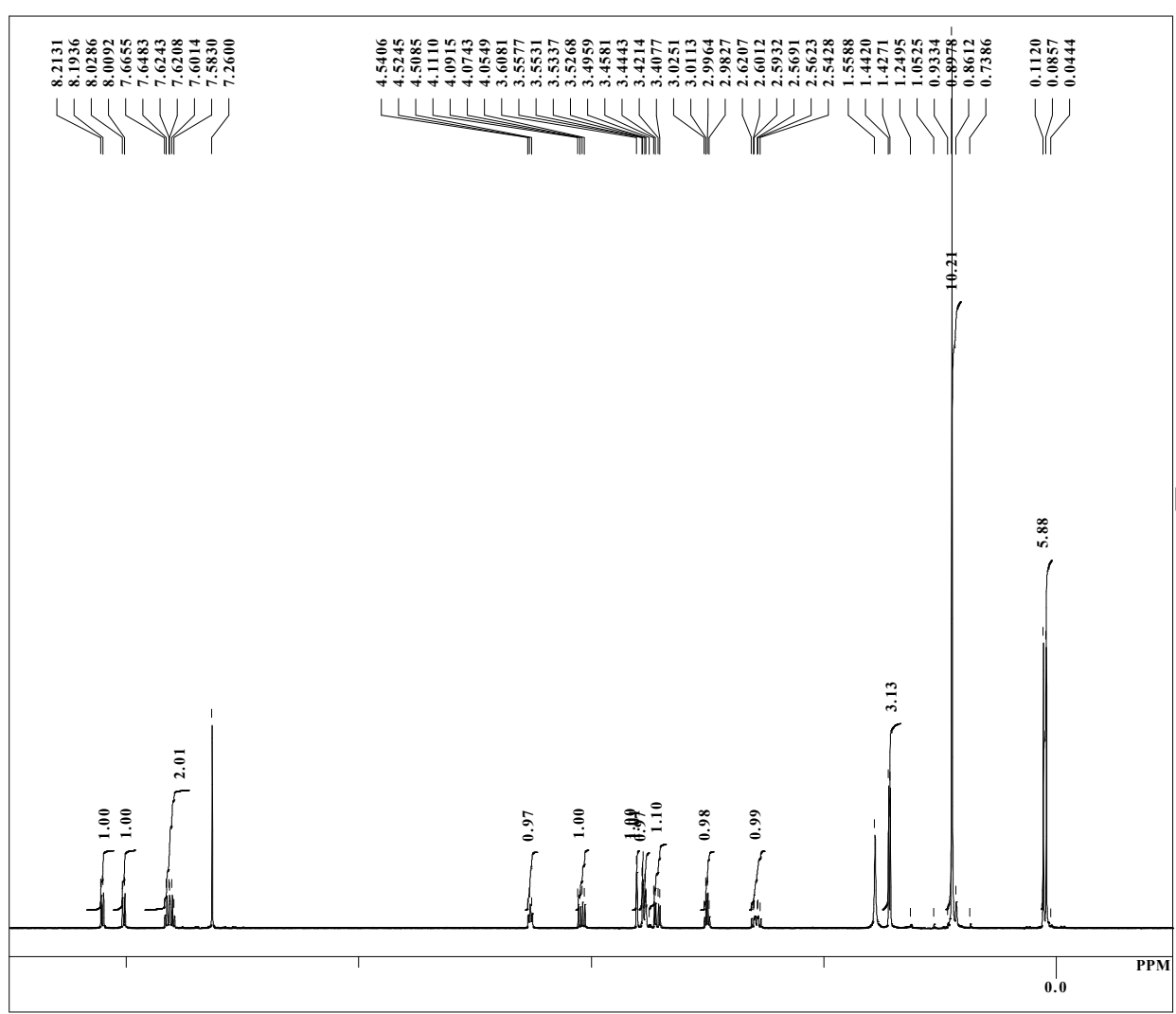

DFILE right muchikan shita SO2Bt OTBS ep

DOMNT

OBNUC

EXMOD
OBFRQ
OBSET

OBFIN

POINT

FREQU

ACQTM
PD

PW1
IRNUC
CTEMP

SLVNT CDCL3

$\begin{array}{lr}\text { EXREF } & 7.26 \mathrm{ppm} \\ \text { BF } & 0.12 \mathrm{~Hz}\end{array}$

15:14:53

ton.jxp
$399.78 \mathrm{MHz}$
$4.19 \mathrm{KHz}$

$4.19 \mathrm{KH} /$
$7.29 \mathrm{~Hz}$

13107

$602.40 \mathrm{H}$
10

10
$2.1837 \mathrm{sec}$
$2.0000 \mathrm{sec}$

$\mathrm{BtO}_{2} \mathrm{~S}$

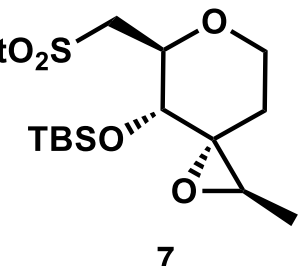

$78 \%$ in 2 steps

single pulse decoupled gated NOE

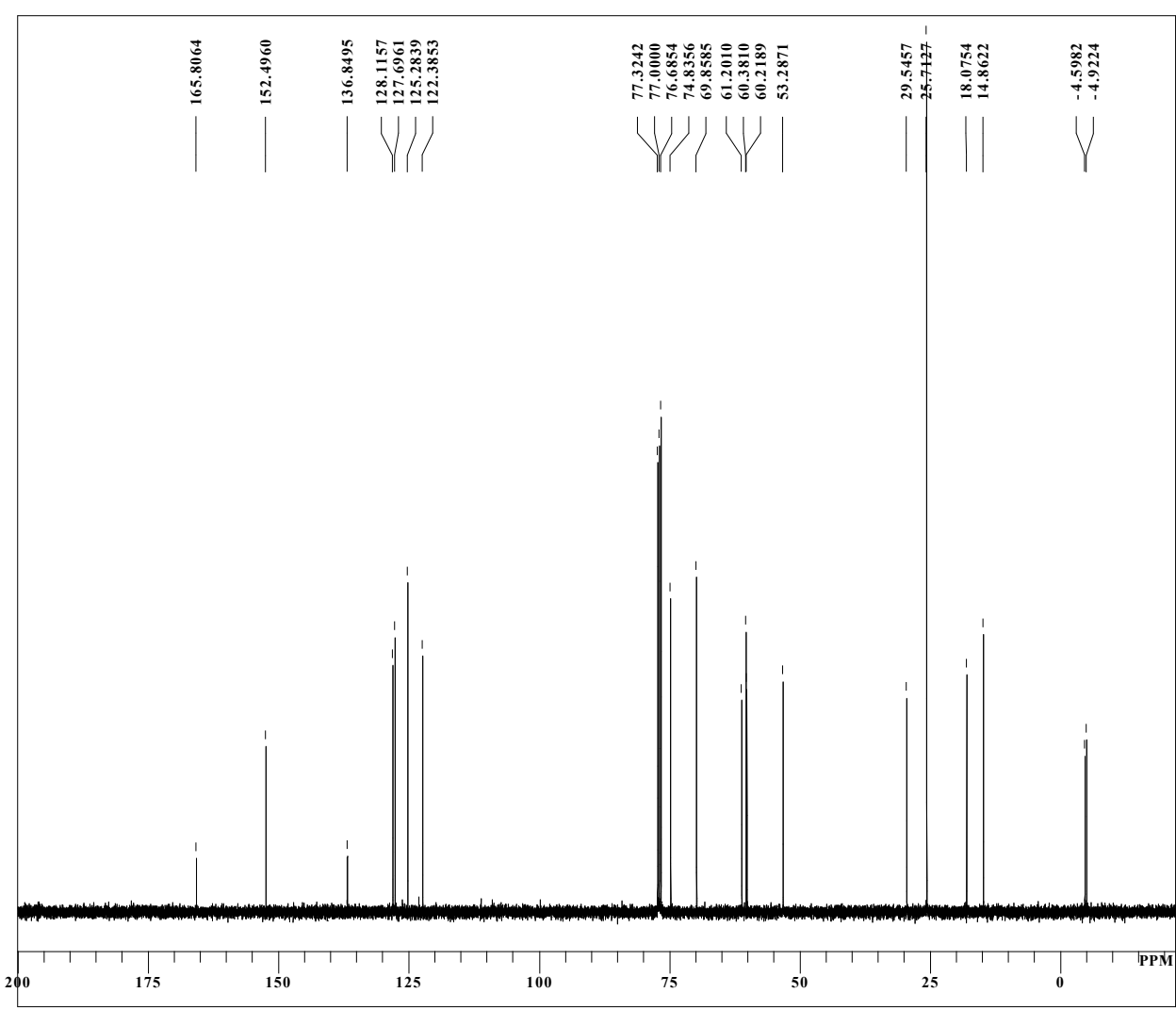

DFILE right muchikan shita SO2Bt OTBS ep

COMNT single pulse decoupled gated NOE

DATIM 2019

OBNUC 13C

EXMOD carbon.jxp
OBFRQ

OBSET $\quad 5.35 \mathrm{KH}$

$\begin{array}{ll}\text { OBSET } & 5.35 \mathrm{KH} \\ \text { OBFIN } & 5.86 \mathrm{~Hz}\end{array}$

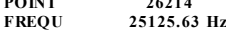

$\begin{array}{lc}\text { FREQU } & 25125.63 \mathrm{H} \\ \text { SCANS } & 274\end{array}$

$\begin{array}{ll}\text { ACQTM } & \mathbf{1 . 0 4 3 3} \mathrm{sec} \\ \mathrm{PD} & \mathbf{2 . 0 0 0 0 \mathrm { sec }}\end{array}$

PW1 3.40 use

$\begin{array}{lc}\text { CTEMP } & 20.5 \mathrm{c} \\ \text { SLVNT } & \text { CDCL3 } 3.00 \mathrm{ppm} \\ \text { EXREF } & 77.12 \mathrm{pm}\end{array}$

$\begin{array}{ll}\text { BF } & 0.12 \mathrm{~Hz} \\ \text { RGAIN } & 60\end{array}$ 
single pulse

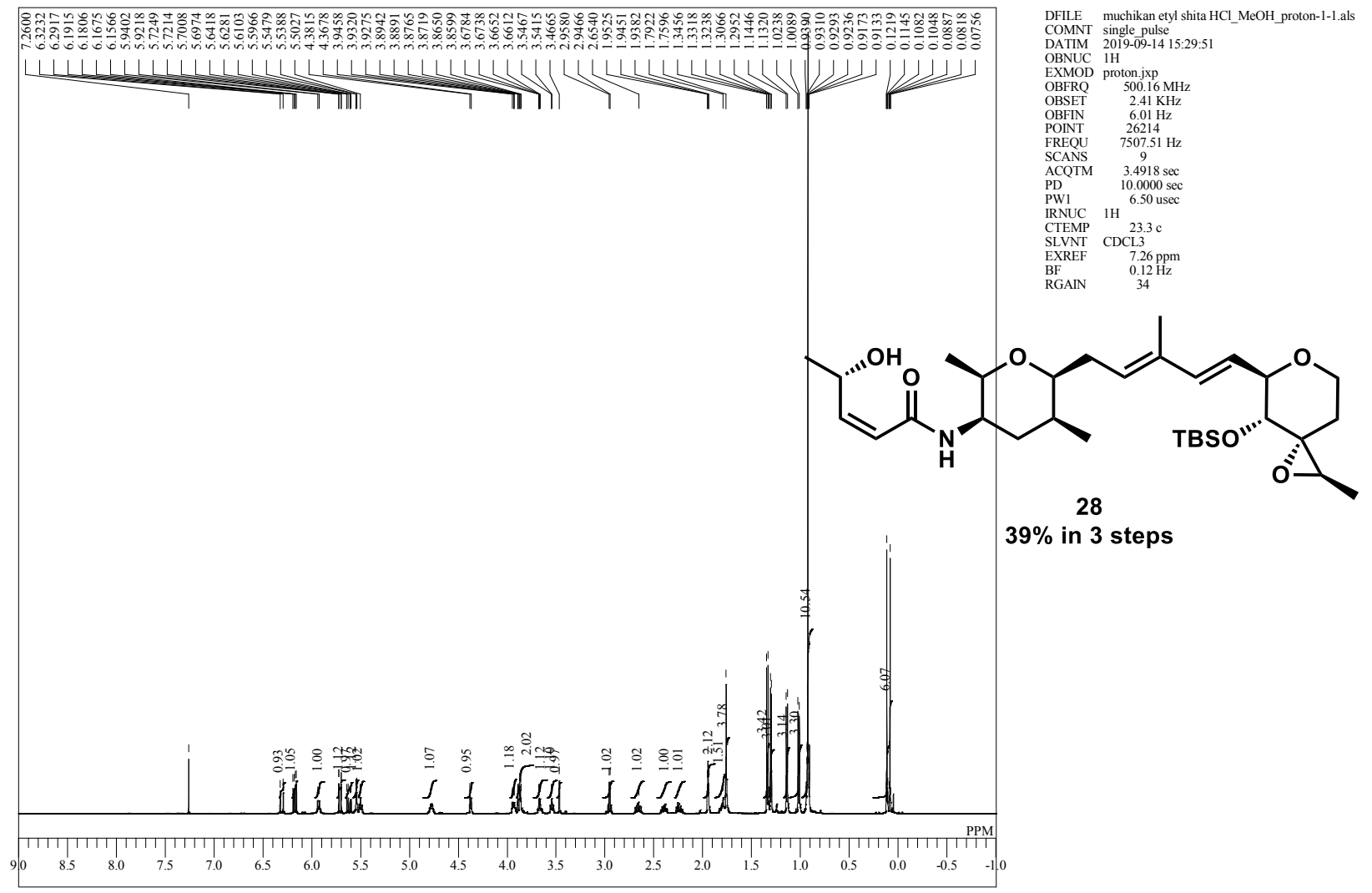

single pulse decoupled gated NOE

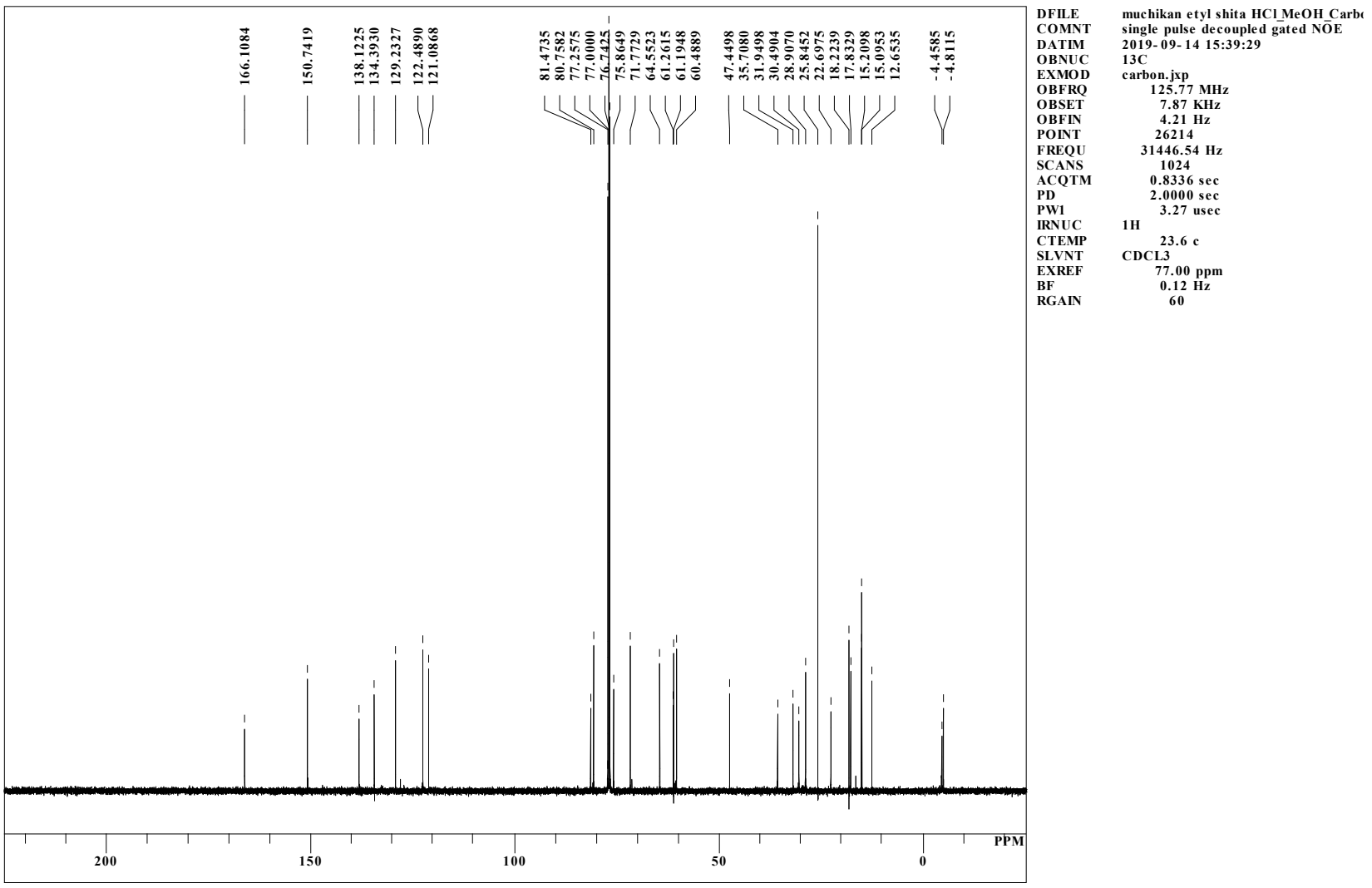




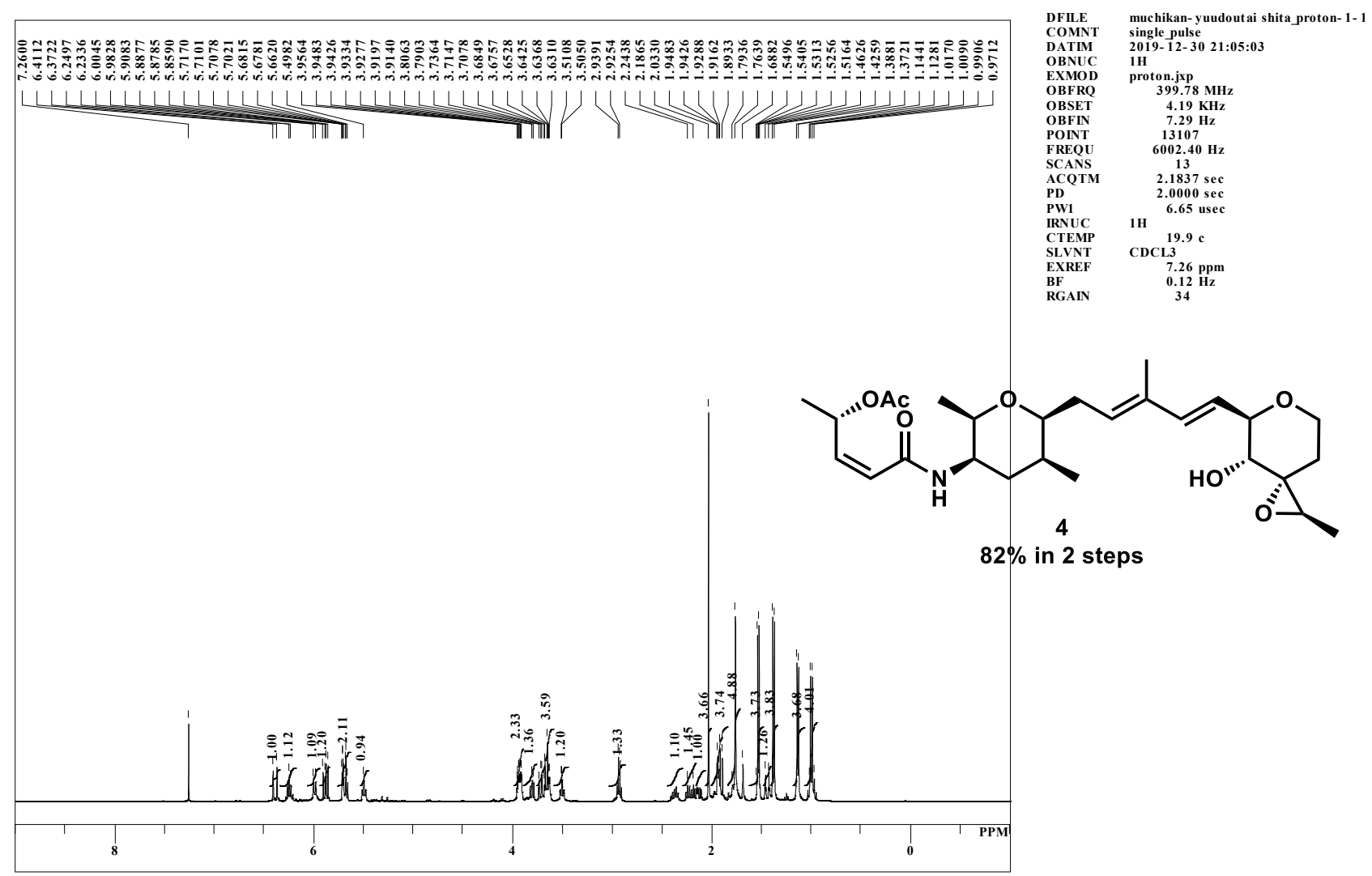

single pulse decoupled gated NOE

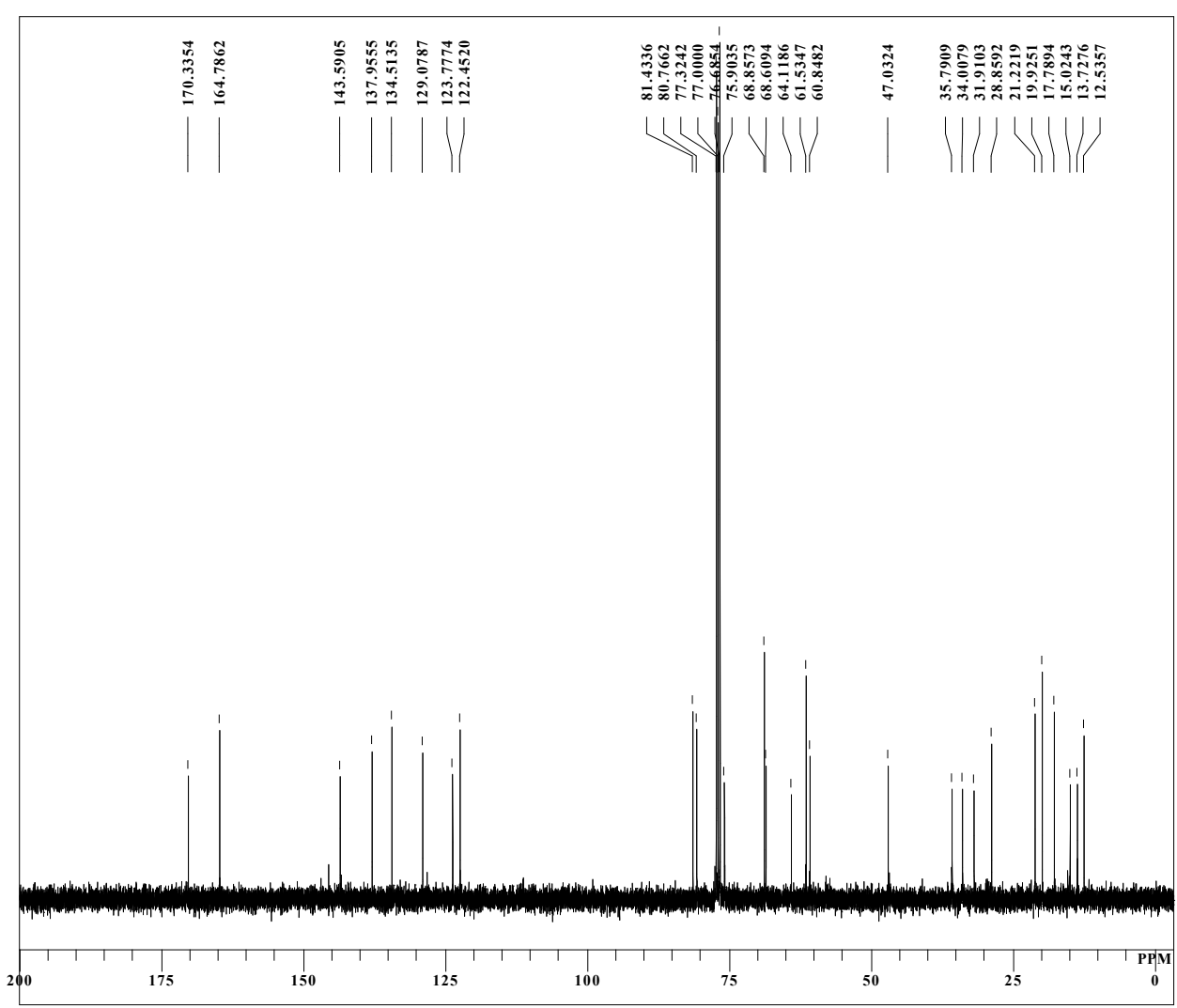

DFILE muchikan-yuudoutai shita_carbon-1-1

COMNT single pulse decoupled gated NOE

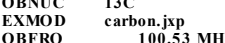

OBSET $\quad 5.53 \mathrm{KH} /$

$\begin{array}{ll}\text { OBSET } & 5.35 \mathrm{KH} \\ \text { OBFN } & 5.86 \mathrm{~Hz}\end{array}$

$\begin{array}{lc}\text { POINT } & 26214 \\ \text { FREQU } & 25125.63 \mathrm{~Hz}\end{array}$

FREQU $25125.63 \mathrm{H}$

$\begin{array}{ll}\text { ACQTM } & 1.0433 \mathrm{sec} \\ \text { PD } & 2.0000 \mathrm{sec}\end{array}$

PWI 3.40 use

CTEMP $20.4 \mathrm{c}$

SLVNT CDCL3 $20.4 \mathrm{c}$

$\begin{array}{lc}\text { CXREF } & 77.00 \mathrm{ppm} \\ \text { BF } & 0.12 \mathrm{~Hz} \\ \text { RGAIN } & 60\end{array}$ 
single pulse

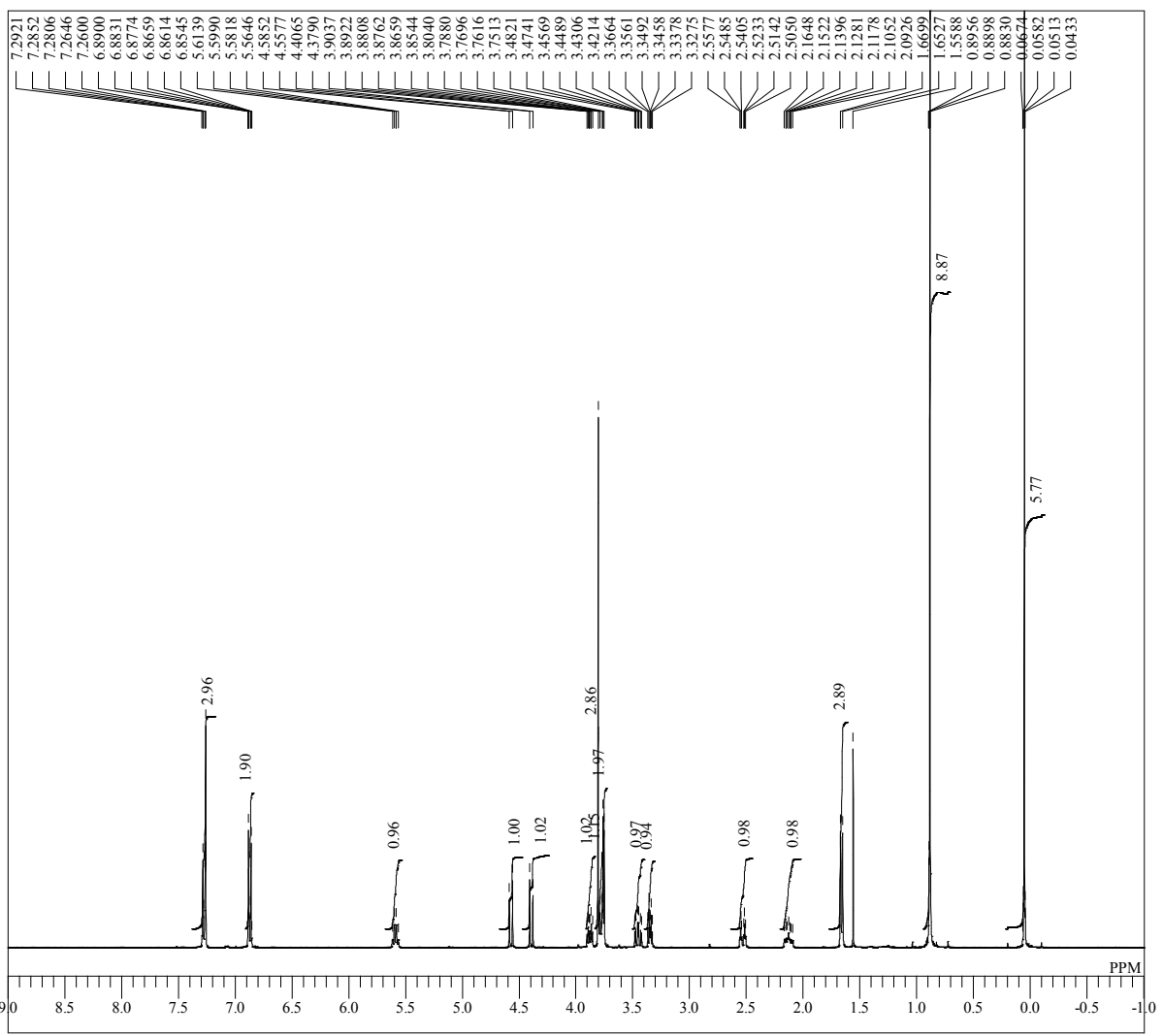

DFILE right muchikan OTBS OPMB etylolefin ue proton-1 COMNT single pulse
DATIM 2019-07-26 21:01:06 OBNUC $1 \mathrm{H}$

XMOD proton.jxp

$\begin{array}{lll}\text { OBRET } & 399.78 \mathrm{MH} \\ \mathrm{OBSET} & 4.12 \mathrm{KHz}\end{array}$

OBFIN

$\begin{array}{ll}\text { POINT } & 13107 \\ \text { FREQU } & 6002.40 \mathrm{~Hz}\end{array}$

$\begin{array}{ll}\text { ACQTM } & 2.1837 \mathrm{sec} \\ \text { PD } & 2.0000 \mathrm{sec}\end{array}$

$\begin{array}{ll}\text { PWl } & 7.25 \text { usec } \\ \text { RNUC } & 1 \mathrm{H}\end{array}$

$22.6 \mathrm{c}$

$\begin{array}{ll}\text { EXREF } & 7.26 \mathrm{ppm} \\ \mathrm{BF} & 0.12 \mathrm{~Hz}\end{array}$

RGAIN $\quad{ }_{44}$

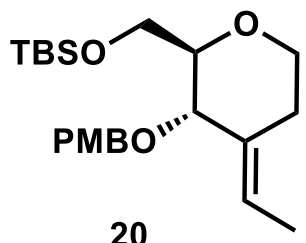

20

$47 \%$

single pulse decoupled gated NOE

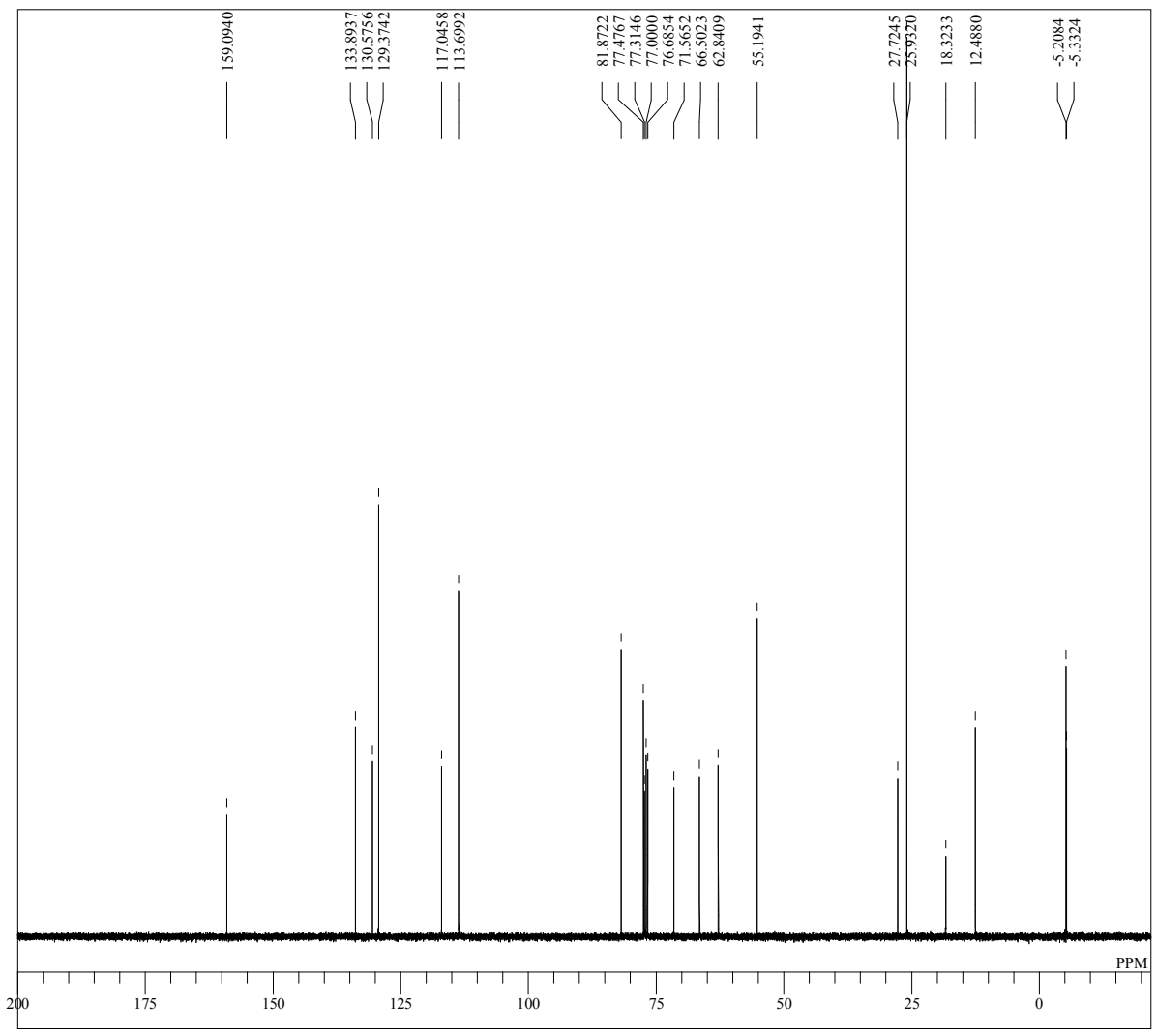

DFILE right muchikan OPMB OTBS etylolefin ue_carbon-1 COMNT single pulse decoupled gated NOE OBNUC 13C

OBFRQ $100.53 \mathrm{MH}$

OBSET $\quad 5.35 \mathrm{KH} Z$

$\begin{array}{ll}\text { OBFIN } & 5.86 \mathrm{~Hz} \\ \text { POINT } & 26214\end{array}$

$\begin{array}{ll}\text { FREQU } & 25125.63 \mathrm{~Hz} \\ \text { SCANS } & 160\end{array}$

$\begin{array}{lc}\text { SCANS } & 160 \\ \text { ACQTM } & 1.0433 \mathrm{sec}\end{array}$

$\begin{array}{ll}\text { PD } & 1.0433 \mathrm{sec} \\ \mathrm{PW} & 3.17 \mathrm{sec}\end{array}$

PW1
IRNUC $1 \mathrm{H}$
3.17 usec

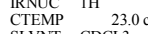

$\begin{array}{lc}\text { CTEMP } & 23.0 \mathrm{c} \\ \text { SLVNT } & \text { CDCL3 } \\ \text { EXREF } & 77.00 \mathrm{ppm}\end{array}$

$\begin{array}{ll}\mathrm{BF} & 0.12 \mathrm{~Hz}\end{array}$$$
60
$$ 
single pulse

F: $\backslash$ SAA論文 $\backslash$ NMR $\backslash$ muchikan OPiv OPMB ethlyolefin ue proton- $1-1$.als

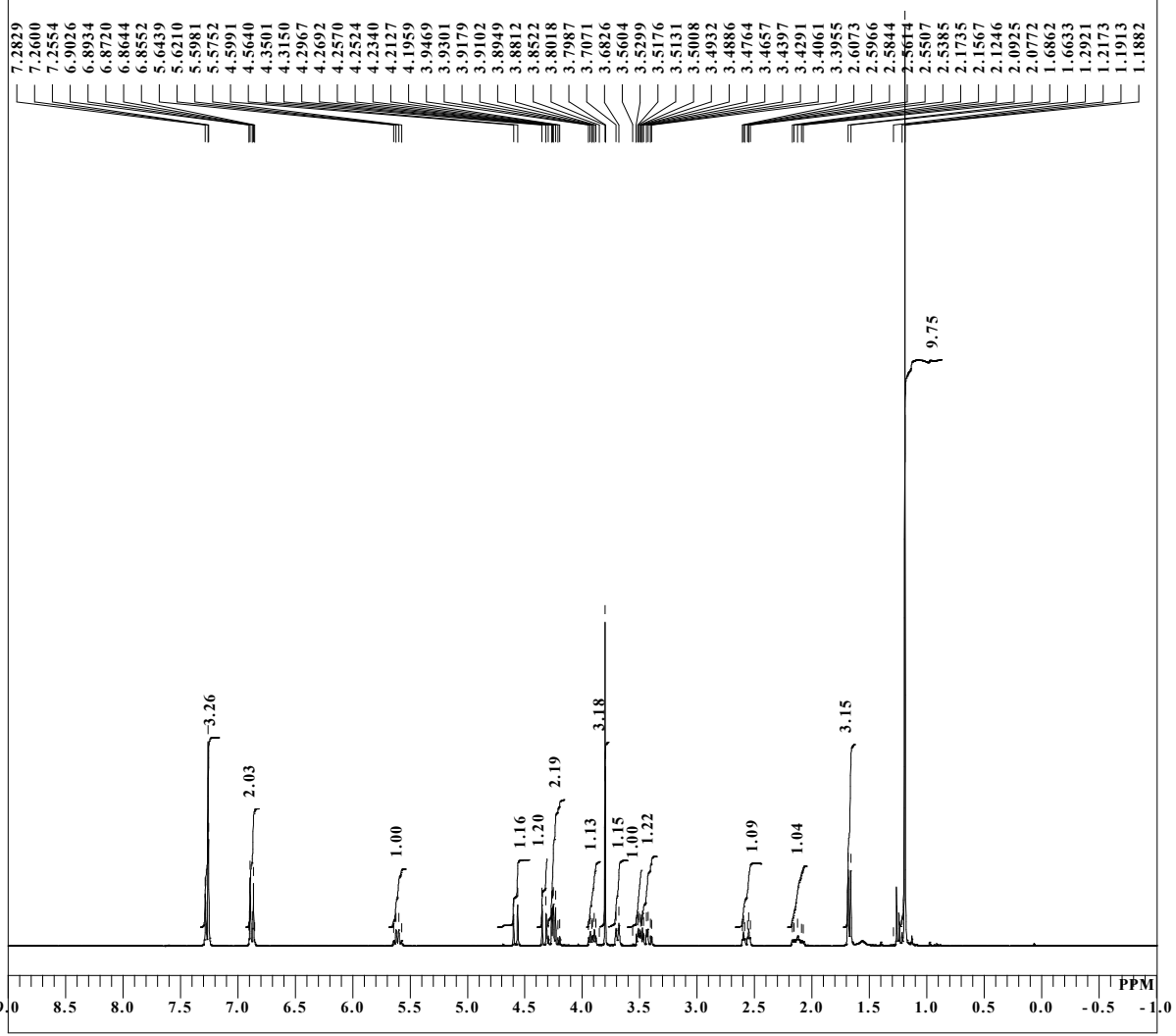

DFILE

COMNT
DATIM

OBNUC

EXMOD
OBFRQ
OBSET

OBFRQ
OBSET
OBFIN
POINT
FREQU

FREQU

SCANS
ACQTM
PD

PD

IRNUC

SLVNT

EXREF

RG

muchikan OPiv OPMB ethlyolefin ue pt single pulse 21:53:58

oton.jxp

$1.15 \mathrm{KHz}$

$1.15 \mathrm{KHz}$
$8.57 \mathrm{~Hz}$

13107
6016.85

$6016.85 \mathrm{H}$

1.16
$1.0000 \mathrm{sec}$

$1 \mathrm{H} 5.50$ use

$\mathrm{CDCL}^{20.0 \mathrm{c}}$

$7.26 \mathrm{ppm}$
$0.12 \mathrm{~Hz}$

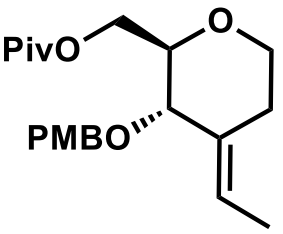

15

$74 \%$ in 2 steps

single pulse decoupled gated NOE

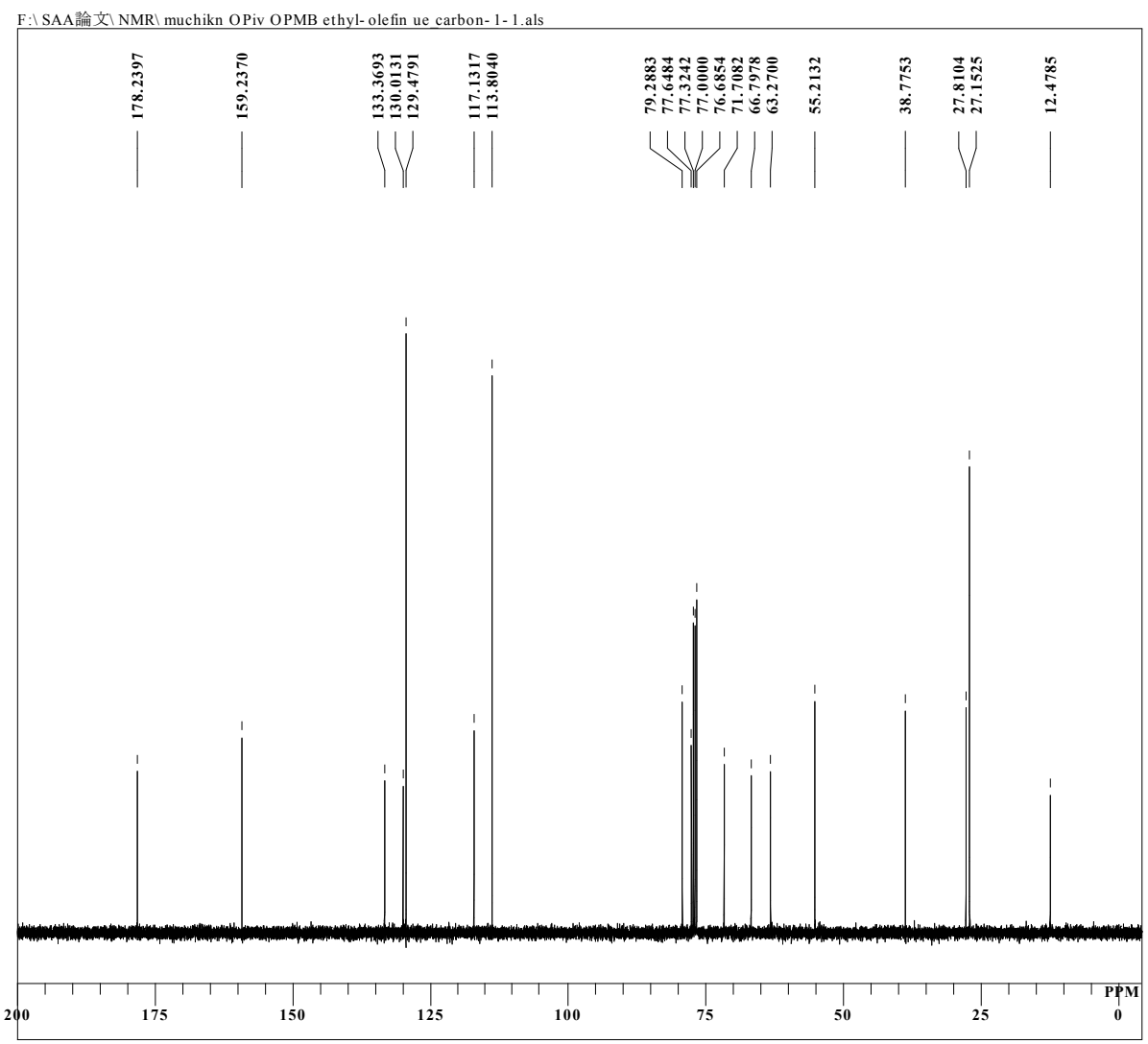

DFILE muchikn OPiv OPMB ethyl- ole fin ue_cs

COMNT single pulse decoupled gated NOE

EXMOD

OBFRQ
OBSET
OBFIN

OBFIN

POINT

FREQU
SCANS
ACQTM

ACQTM
PD

PW1

2019- 06-10 22:52:42

carbon.jxp
$100.53 \mathrm{MH}$

$5.35 \mathrm{KHz}$
$5.86 \mathrm{~Hz}$

$5.35 \mathrm{KHz}$
$5.86 \mathrm{~Hz}$

$25125.63 \mathrm{~Hz}$

$25125.63 \mathrm{~Hz}$
85

$1.0433 \mathrm{sec}$
$2.0000 \mathrm{sec}$

3.17 use
IH

CTEMP
SLVNT

$\begin{array}{ll}\text { SLVNT } & \text { CDCL3 } \\ \text { EXREF } & 77.00 \mathrm{ppm}\end{array}$

BF $\quad 0.12 \mathrm{~Hz}$

$77.00 \mathrm{ppm}$
$0.12 \mathrm{~Hz}$
60 
single_pulse

F: $\backslash$ SAA論文 $\backslash N M R \backslash$ muchikan $O P i v O H$ ethylepoxy ue proton-1-1.als

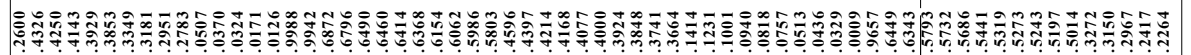
Ff

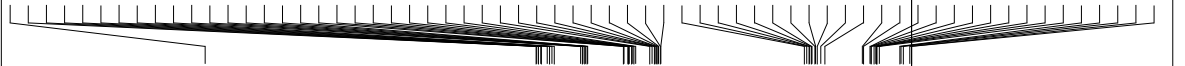

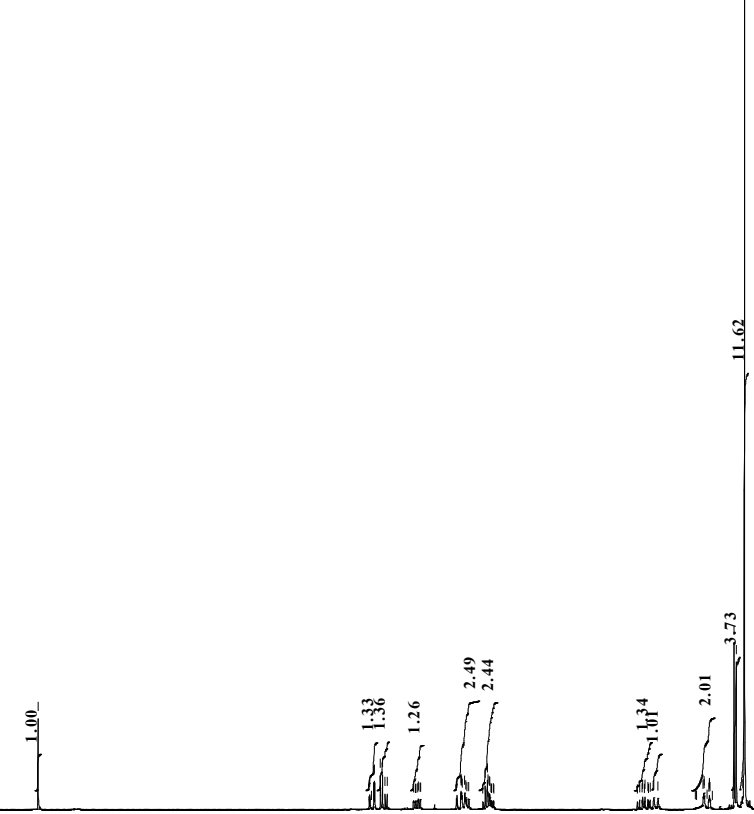

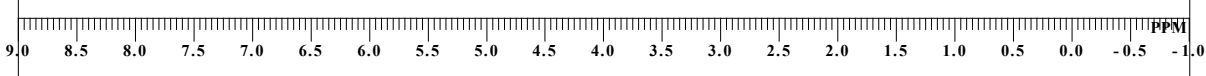

single pulse decoupled gated NOE

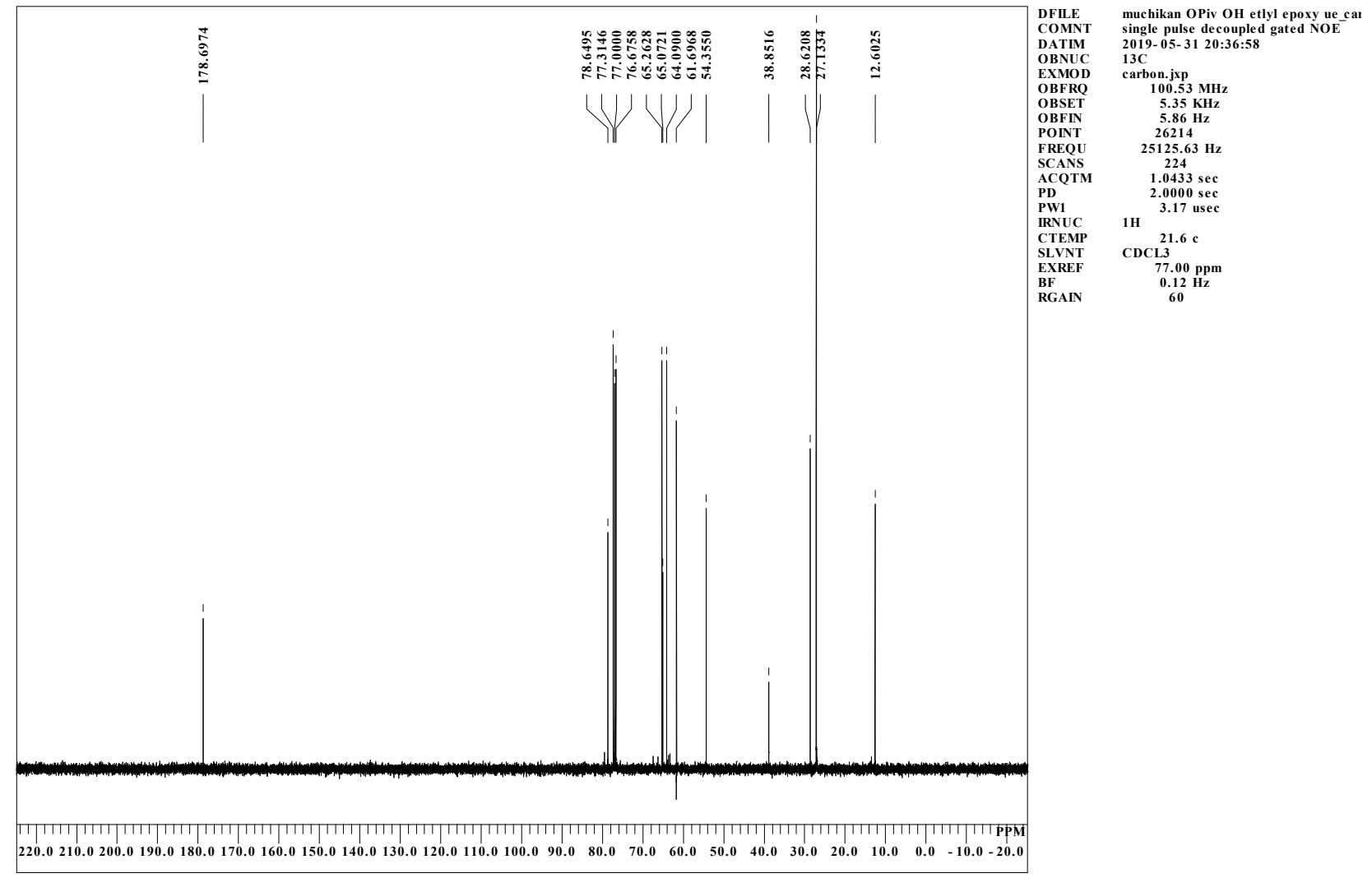

DFILE

COMNT
DATIM

OBNUC

EXMOD

OBSET

POINT

FREQU
SCANS

ACQTM
PD

PD

IRNUC

SLVNT
EXREF

EXREF

RGAIN

uchikan $\mathrm{OPiv} \mathrm{OH}$ ethylepoxy ue prot single_pulse
2019-05-31 20:04:53

$1 \mathrm{H}$

$300.53 \mathrm{MHz}$
$1.15 \mathrm{KHz}$

$1.15 \mathrm{KHz}$
$8.57 \mathrm{~Hz}$

13107
6016.85

$6016.85 \mathrm{H}$
16

16
$2.1784 \mathrm{sec}$
$1.0000 \mathrm{sec}$

H 5.50 usec

CDCL3

$7.26 \mathrm{ppm}$
$0.12 \mathrm{~Hz}$

Pivo<smiles>C[C@@H]1O[C@]12CCO[C@H](CO)[C@H]2O</smiles>

23

$82 \%$ in 2 steps 
single_pulse

F: $\backslash$ SAA論文 $\backslash$ NMR $\backslash$ muchikan OH OTBS ethyl epoxy ue proton-1-1.als

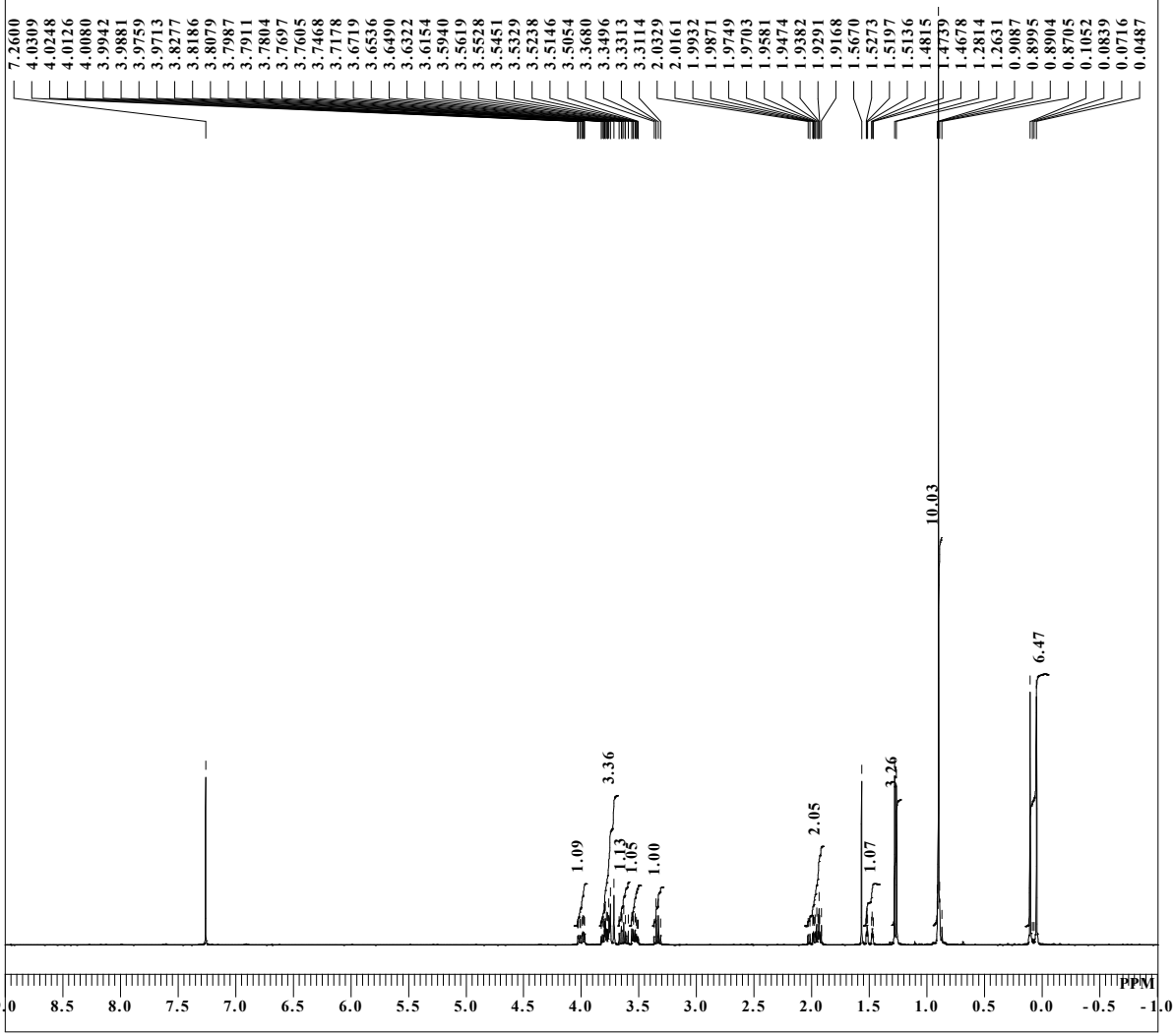

DFILE

DOMNT

OBNUC

EXMOD
OBFRQ
OBSET

OBSET

OBFIN

SCANS

D

PW1

IRNUC
CTEMP

SLVNT

EXREF

chikan OH OTBS ethyl epoxy ue pr

single pulse 22:34:35

roton.jxp

$1.15 \mathrm{KHz}$

$1.15 \mathrm{KHz}$
$8.57 \mathrm{~Hz}$

13107
6016.85
17

6016.85
11

$2.1784 \mathrm{sec}$
$1.0000 \mathrm{sec}$

$1 \mathrm{H} \quad 5.50$ usec

$\operatorname{CDCL3}^{21.1}$

$\begin{array}{ll}\text { XREF } & 7.26 \mathrm{ppm} \\ \text { GFAIN } & 0.12 \mathrm{~Hz}\end{array}$

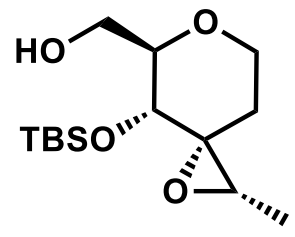

26

$64 \%$ in 2 steps

single pulse decoupled gated NOE

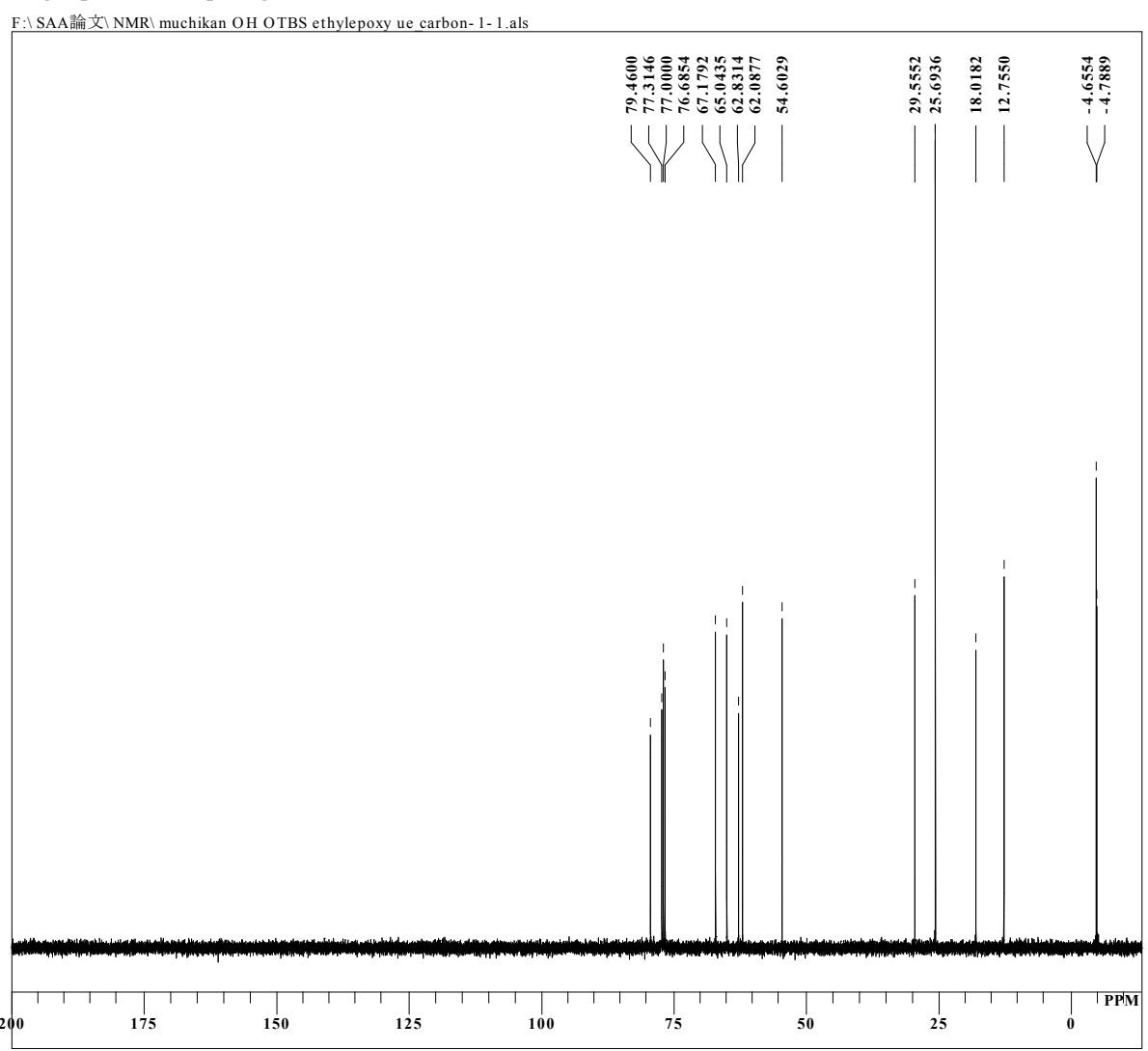

single pulse decoupled gated NOE

DATIM

OBFRQ

OBSET

OBFIN

POINT

FREQU
SCANS
ACQTM

ACQTM
PD

PW1

$13 \mathrm{C}$

$100.53 \mathrm{MHz}$

$5.35 \mathrm{KHz}$
$5.86 \mathrm{~Hz}$

$5.35 \mathrm{KH} /$
$5.86 \mathrm{~Hz}$

26214

$25125.63 \mathrm{~Hz}$

$1.0433 \mathrm{sec}$
$2.0000 \mathrm{sec}$

1H 3.17 usec

CTEMP
SLVNT

EXREF CDCL3 $77.00 \mathrm{ppm}$

$\begin{array}{lc}\text { EXREF } & 77.00 \mathrm{ppm} \\ \text { BF } & 0.12 \mathrm{~Hz} \\ \text { RGAIN } & 60\end{array}$ 
single_pulse

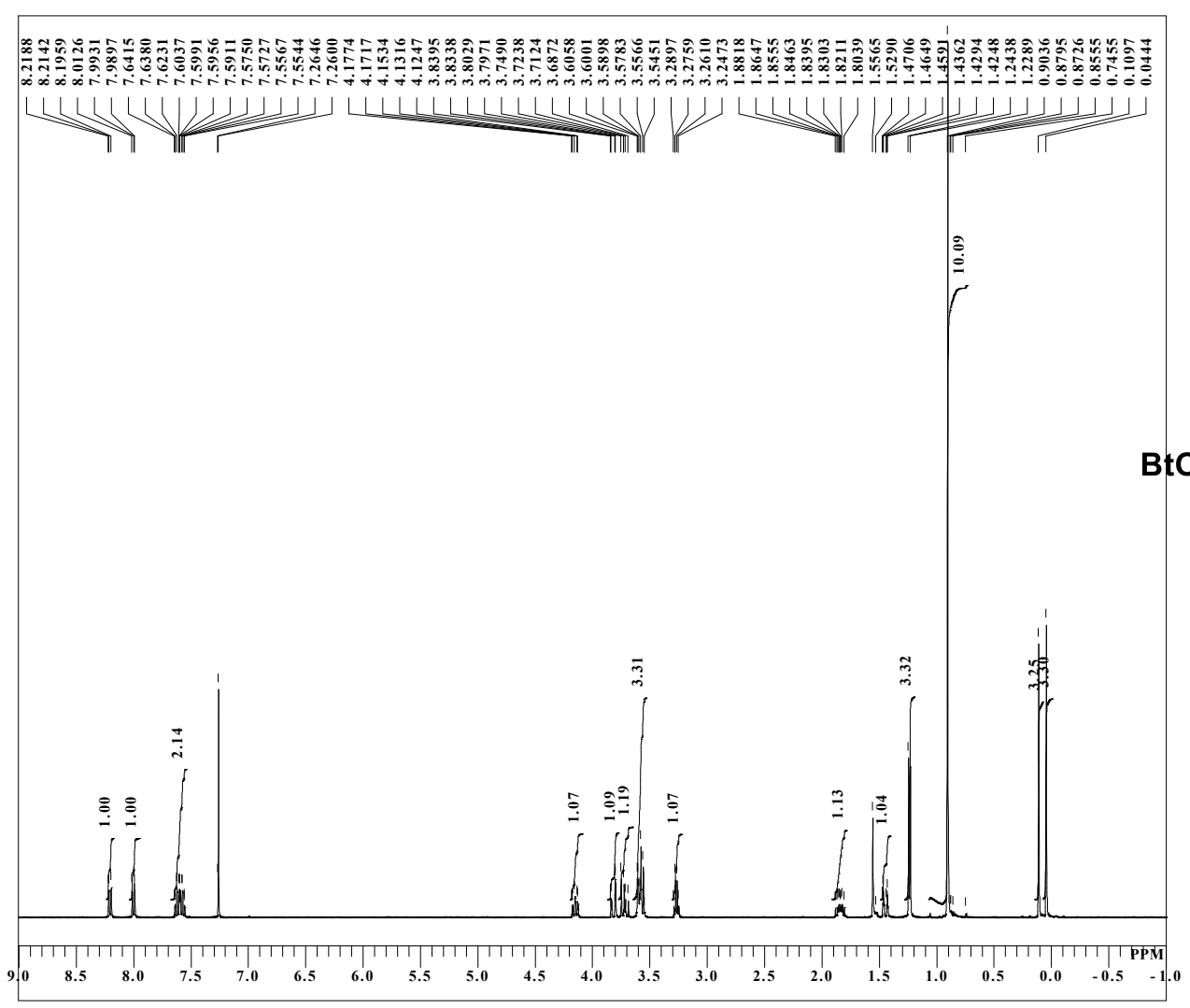

DFILE right muchikan ue So2Bt-OTBS epox

EXMOD

OBFRQ

OBFET

POINT

FREQU

ACQTM

PD

PW1
IRNUC $1 \mathrm{H}$
CTEMP

SLVNT CDCL3

$\begin{array}{ll}\text { SLVNT } & \text { CDCL3 } \\ \text { EXREF } & 7.26 \mathrm{ppm}\end{array}$

RGAN

ingle pulse $23: 13: 40$

$399.78 \mathrm{MHz}$
roton.jxp

$399.78 \mathrm{MHz}$
$4.19 \mathrm{KHz}$

$4.19 \mathrm{KH}$
$7.29 \mathrm{~Hz}$

13107

$1837 \mathrm{sec}$
$.0000 \mathrm{sec}$

$7.26 \mathrm{ppm}$
$0.12 \mathrm{~Hz}$

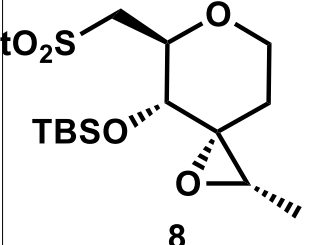

$69 \%$ in 2 steps

single pulse decoupled gated NOE

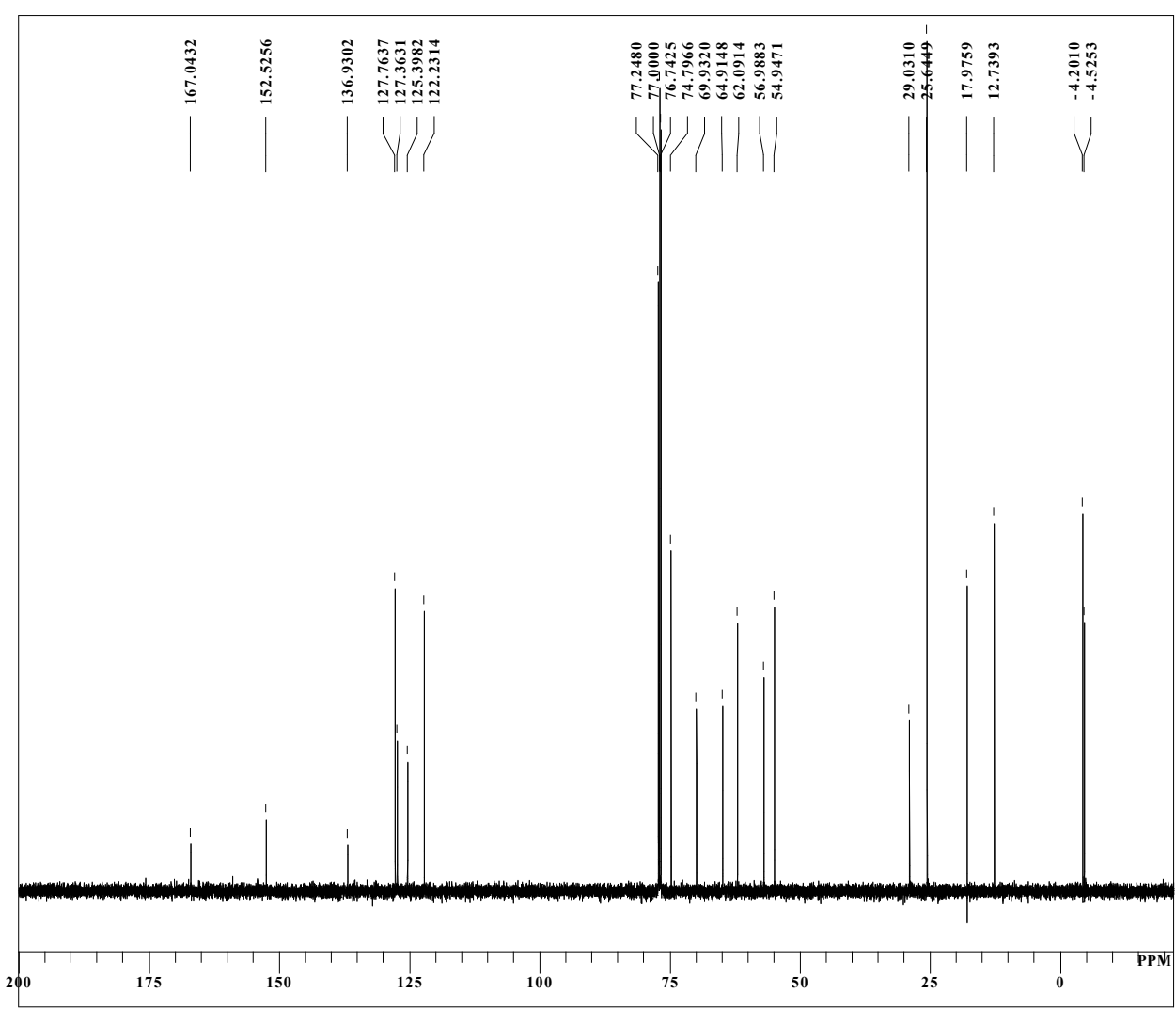

DFILE right muchikan ue SO2Bt OTBS epox

single pulse decoupled gated $\mathrm{NOE}$

DATIM

OBNUC

EXMOD
OBFRQ

OBSET $\quad 7.87 \mathrm{KH}$

OBFIN $\quad 4.21 \mathrm{~Hz}$

$\begin{array}{ll}\text { POINT } & \mathbf{2 6 2 1 4} \\ \text { FREQU } & \mathbf{3 1 4 4 6 . 5 4} \mathrm{Hz}\end{array}$

$\begin{array}{ll}\text { FREQU } & 31446.54 \\ \text { SCANS } & 336\end{array}$

$\begin{array}{ll}\text { ACQTM } & 0.8336 \mathrm{sec} \\ \text { PD } & 1.0000 \mathrm{sec}\end{array}$

$\begin{array}{lr}\text { PD } & \mathbf{1 . 0 0 0 0 ~ s e c} \\ \text { PW1 } & 3.27 \text { usec }\end{array}$

CTEMP $21.3 \mathrm{c}$

SLVNT CDCL3

$\begin{array}{lc}\text { EXREF } & 77.00 \mathrm{ppm} \\ \text { BF } & 0.12 \mathrm{~Hz} \\ \text { RGAIN } & 60\end{array}$ 
single pulse

F:\SAA論文 $\backslash$ NMR $\backslash$ muchikan HCIMeOH ue proton-1-1.als

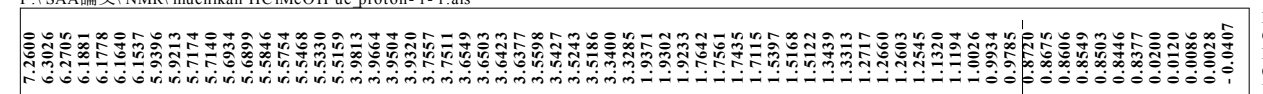
DOME DATIM
OBNUC $|L|+\mid$

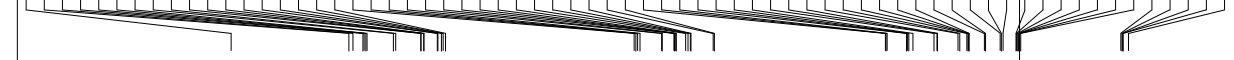

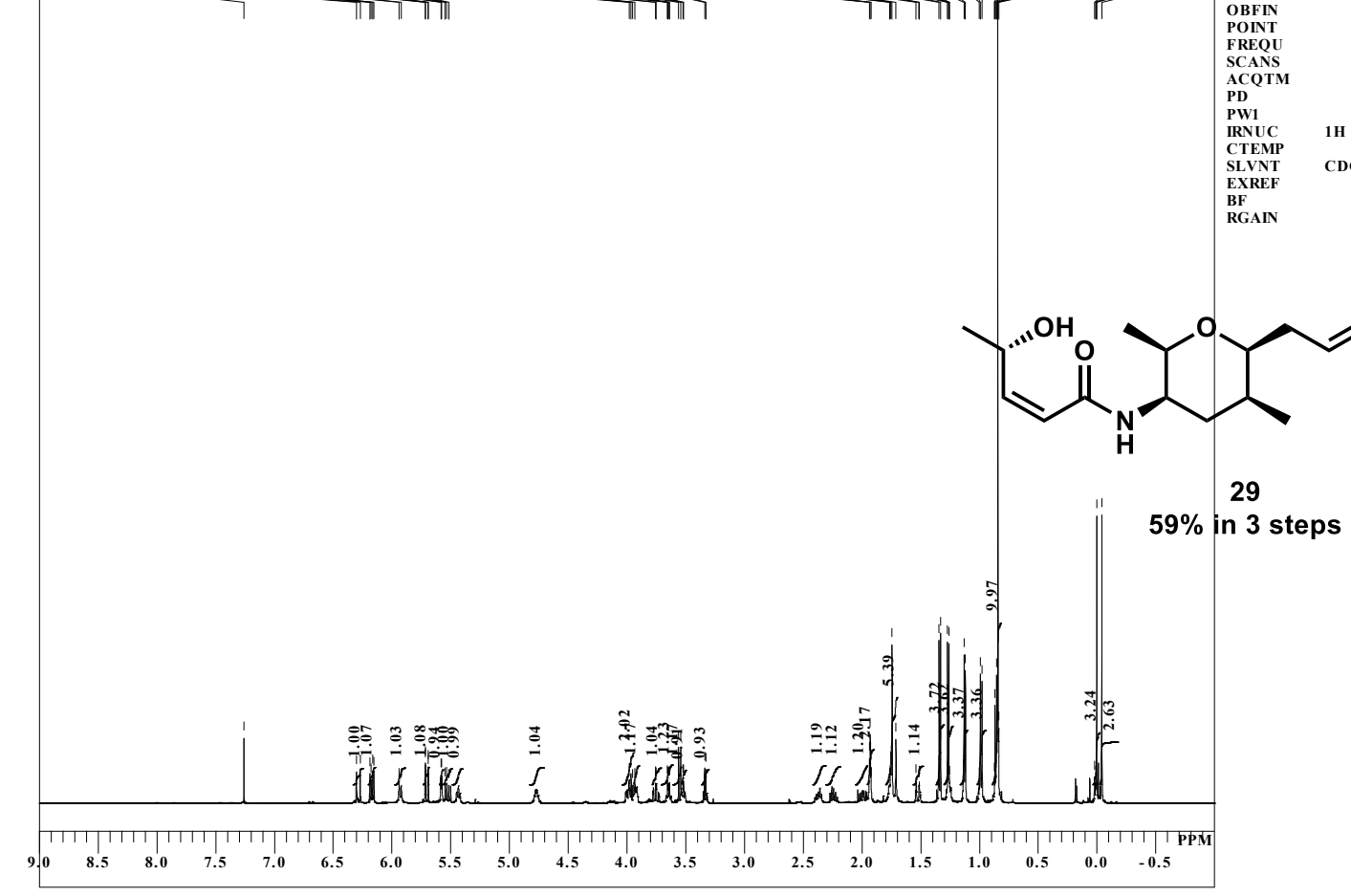

muchikan $\mathrm{HCIMeOH}$ ue proton-1-1.a single pulse $21: 54: 35$ H $500.16 \mathrm{MHz}$
$2.41 \mathrm{KHz}$ $2.16 \mathrm{KH} 2$
$6.01 \mathrm{~Hz}$ 13107
$7507.51 \mathrm{H}$ $7507.51 \mathrm{H}$ 21
$1.7459 \mathrm{sec}$
$2.0000 \mathrm{sec}$ $2.0000 \mathrm{sec}$
6.50 usec 21.6 $\stackrel{21.6 \mathrm{c}}{\mathrm{DCL} 3}$ $7.26 \mathrm{ppm}$
0.12
$3 \mathrm{~Hz}$

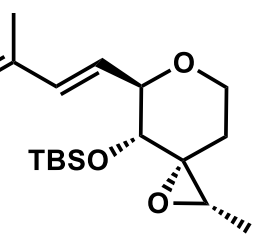

single pulse decoupled gated NOE

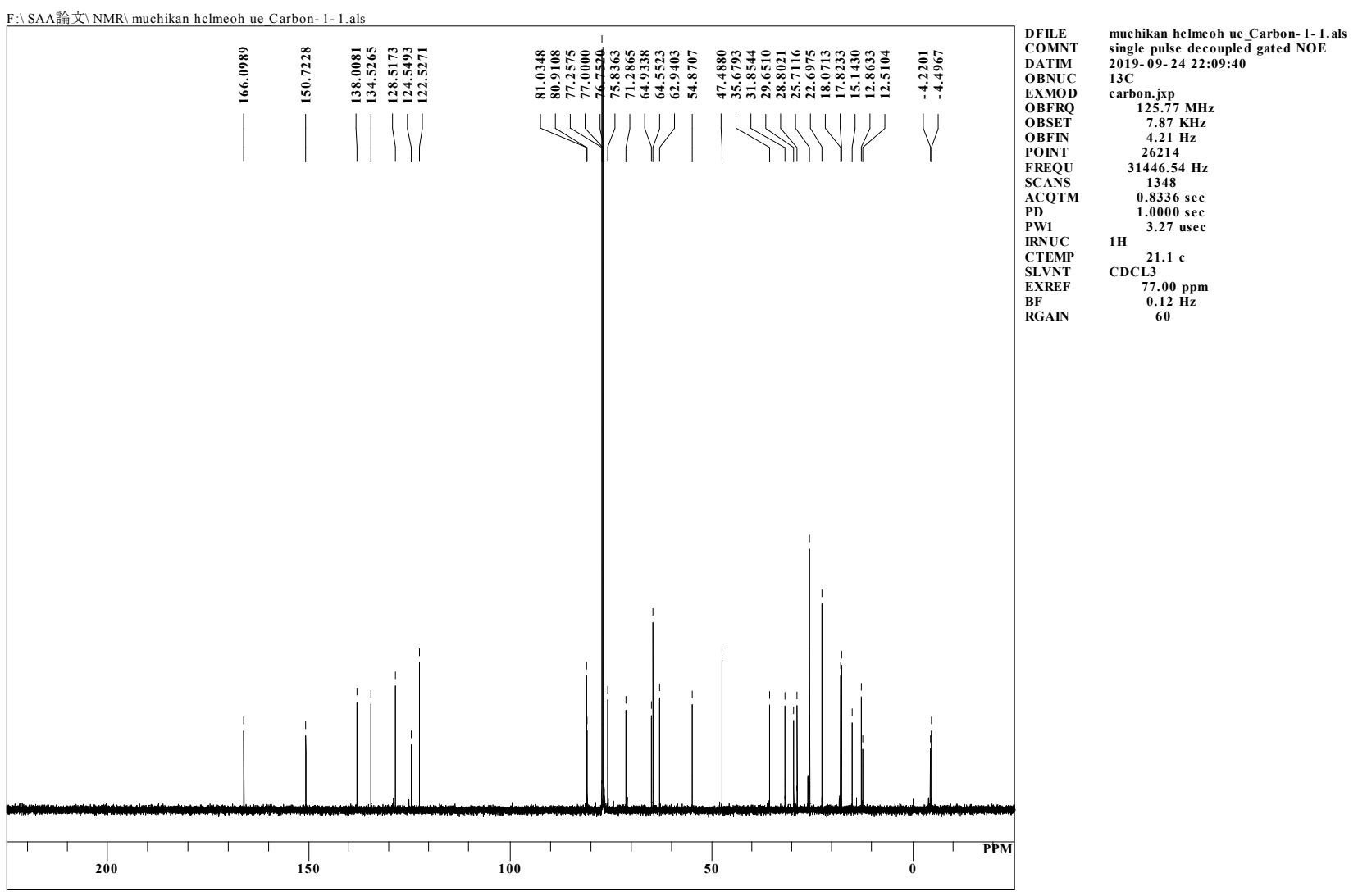


single pulse

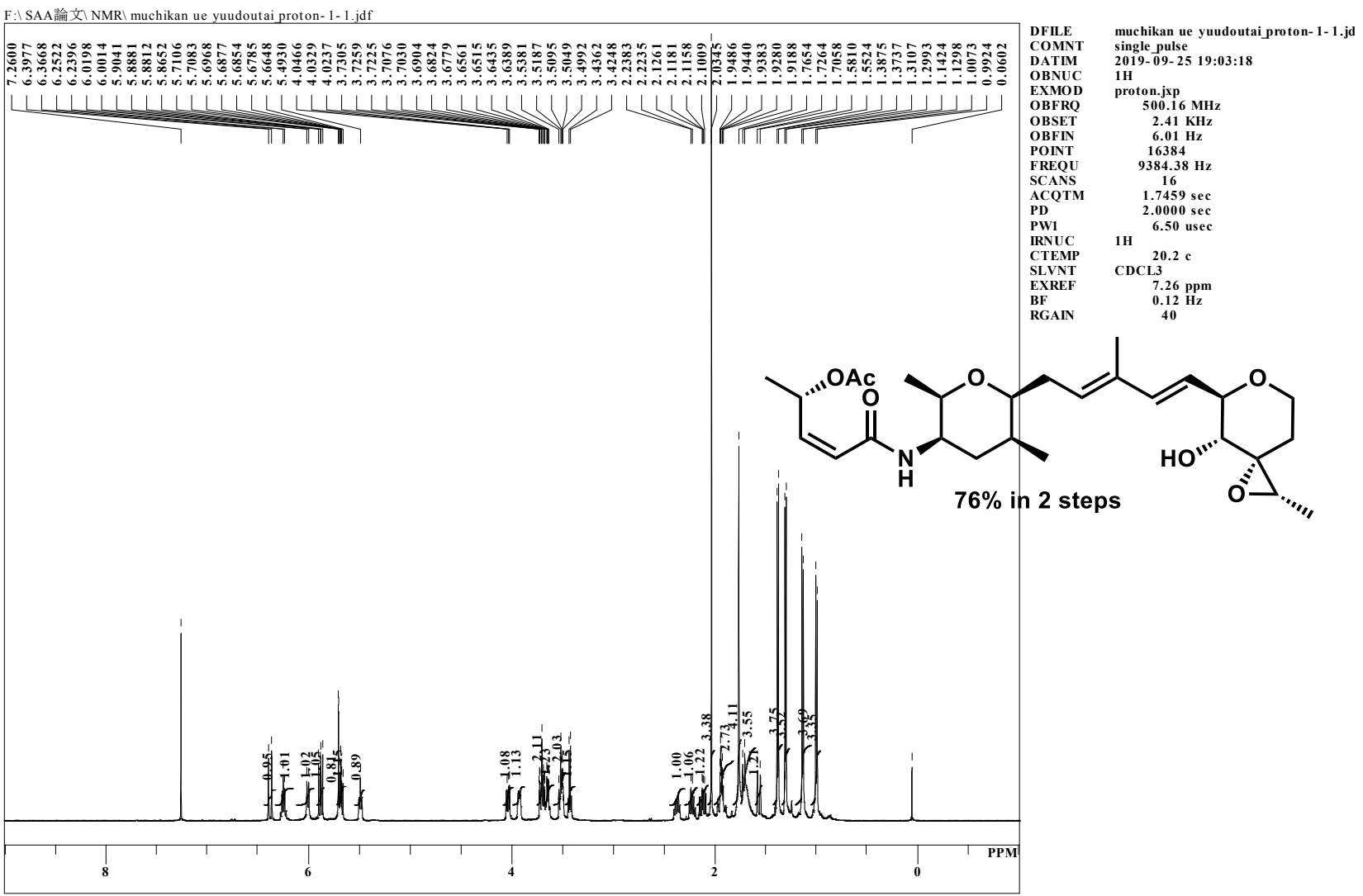

single pulse decoupled gated NOE

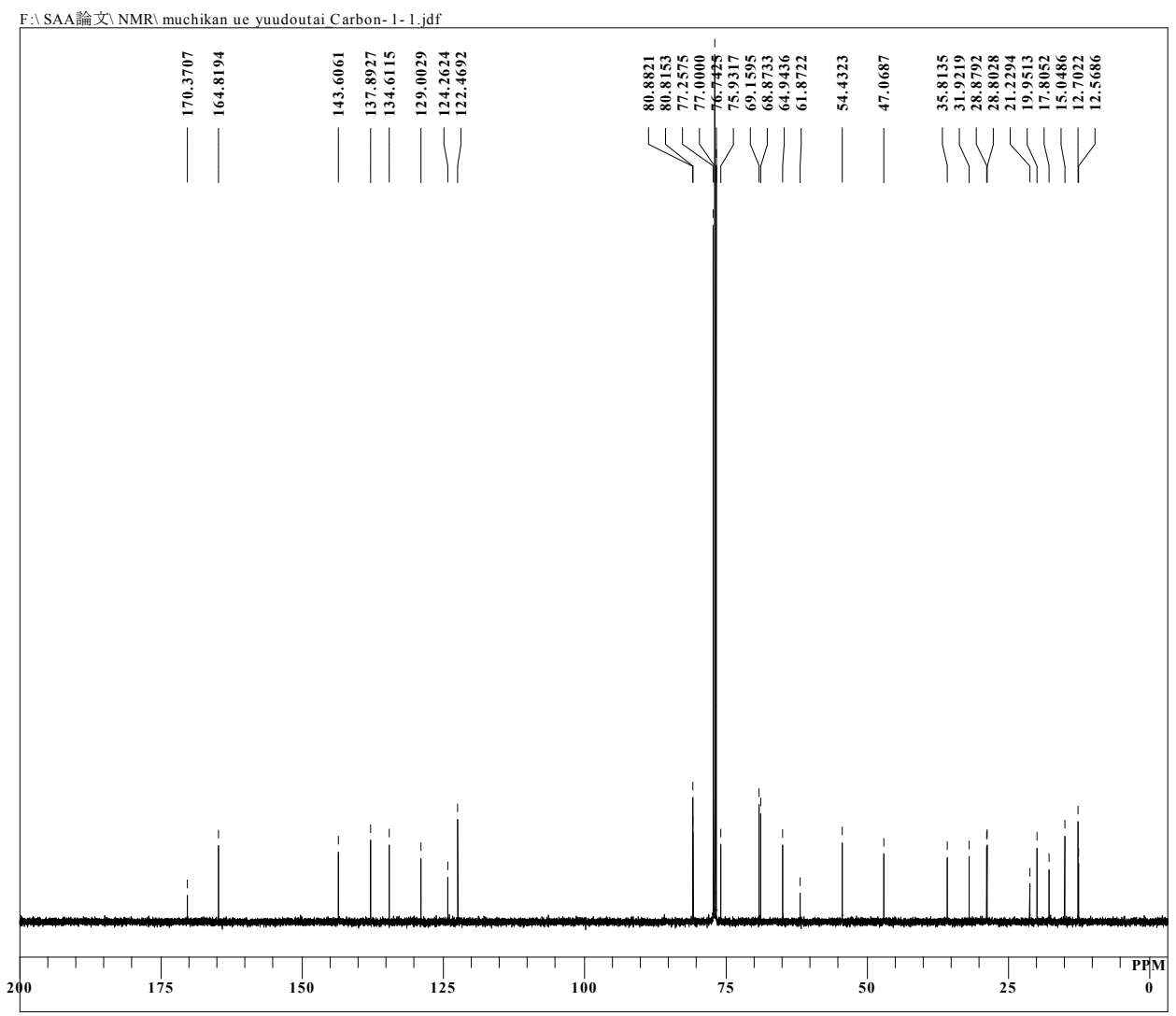

